December 1999 • NREL/SR-520-26957

\title{
Renewable Energy Markets in China: An Analysis of Renewable Energy Markets in Guangdong, Jiangxi, Jilin, and Yunnan Provinces, with Updated Information from Beijing
}

Scott B. Vaupen Xinergy Resources San Francisco, CA
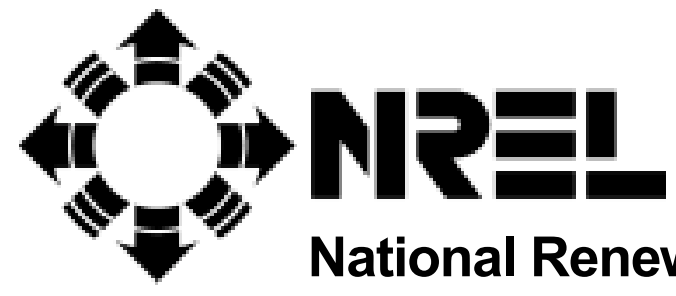

National Renewable Energy Laboratory

1617 Cole Boulevard

Golden, Colorado 80401-3393

NREL is a U.S. Department of Energy Laboratory

Operated by Midwest Research Institute $\bullet$ Battelle $\bullet$ Bechtel

Contract No. DE-AC36-99-G010337 


\section{Renewable Energy Markets in China: An Analysis of Renewable Energy Markets in Guangdong, Jiangxi, Jilin, and Yunnan Provinces, with Updated Information from Beijing}

Scott B. Vaupen Xinergy Resources San Francisco, CA

NREL Technical Monitor: Debra Lew

Prepared under Subcontract No. AAX-8-18676-01

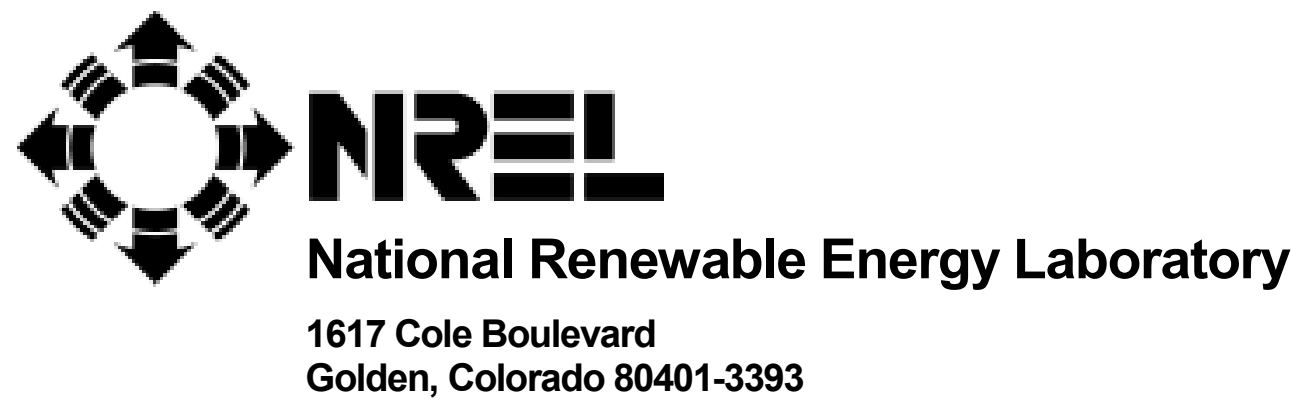

NREL is a U.S. Department of Energy Laboratory Operated by Midwest Research Institute $\bullet$ Battelle $\bullet$ Bechtel Contract No. DE-AC36-99-G010337 


\section{NOTICE}

This report was prepared as an account of work sponsored by an agency of the United States government. Neither the United States government nor any agency thereof, nor any of their employees, makes any warranty, express or implied, or assumes any legal liability or responsibility for the accuracy, completeness, or usefulness of any information, apparatus, product, or process disclosed, or represents that its use would not infringe privately owned rights. Reference herein to any specific commercial product, process, or service by trade name, trademark, manufacturer, or otherwise does not necessarily constitute or imply its endorsement, recommendation, or favoring by the United States government or any agency thereof. The views and opinions of authors expressed herein do not necessarily state or reflect those of the United States government or any agency thereof.

Available electronically at http://www.doe.gov/bridge

Available for a processing fee to U.S. Department of Energy

and its contractors, in paper, from:

U.S. Department of Energy

Office of Scientific and Technical Information

P.O. Box 62

Oak Ridge, TN 37831-0062

phone: 865.576.8401

fax: 865.576.5728

email: reports@adonis.osti.gov

Available for sale to the public, in paper, from:

U.S. Department of Commerce

National Technical Information Service

5285 Port Royal Road

Springfield, VA 22161

phone: 800.553.6847

fax: 703.605.6900

email: orders@ntis.fedworld.gov

online ordering: http://www.ntis.gov/ordering.htm

Printed on paper containing at least $50 \%$ wastepaper, including $20 \%$ postconsumer waste 


\section{Preface}

This report is an assessment of the state of renewable energy markets in summer 1998 in the Chinese provinces of Guangdong, Jiangxi, Jilin, and Yunnan, with updated information from Beijing. The document is a continuation of a 1997 report that details the result of visits made to six provinces.

The first section of this report provides a detailed listing of the central government agencies in China involved in renewable energy activities, along with a description of central government policies and regulations. State incentives to promote new high-technology businesses are also discussed, including tax and tariff breaks, loan incentives, and other assistance involving joint ventures and foreign exchange. The section concludes with an outline of potential obstacles to the growth of renewable energy markets. The remaining four sections examine the legal, competitive, economic, geographic, technological, and sociocultural environments in Guangdong, Jiangxi, Jilin, and Yunnan. The report concludes with appendices that provide detailed information on Chinese companies, wind measurement statistics for Guangdong Province, project approval procedures for both large and small companies, foreign loan sources, the biomass circulating fluidized-bed gasifier project, and the Rehai, Tengchong County, geothermal field.

This composite document provides only some of the information gathered during the 1998 visit; more detailed, customized information, pertinent to specific sectors of the U.S. renewable energy industry, is best conveyed directly to individual renewables companies. 


\section{Table of Contents}

Preface

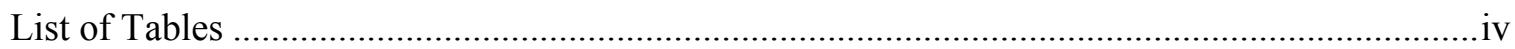

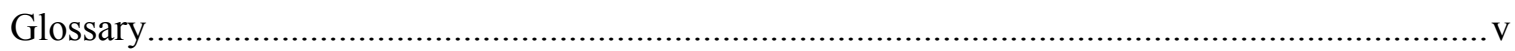

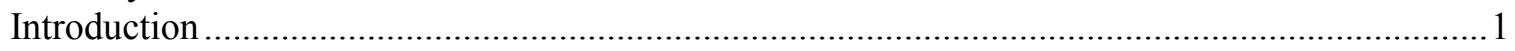

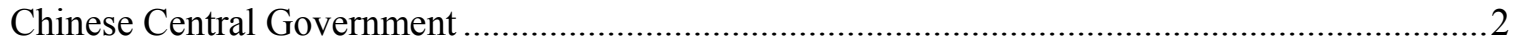

Central Government Agencies Involved with Renewable Energy....................................

Central Government Policies and Regulations .............................................................. 4

State Incentives to Promote New High-Technology Enterprises .........................................5

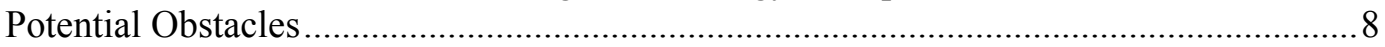

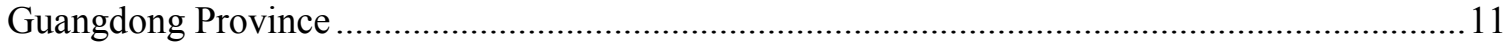

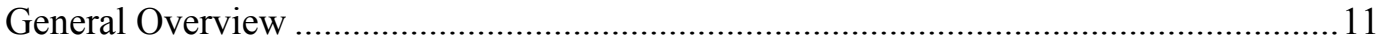

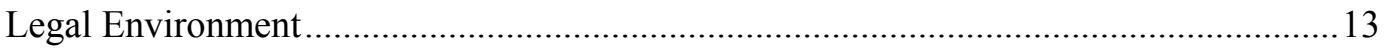

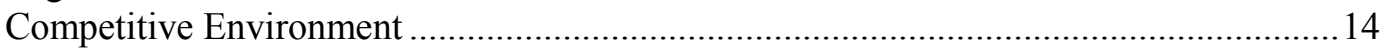

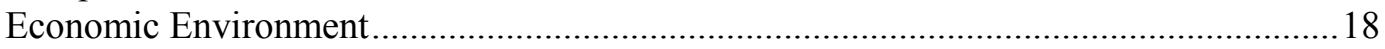

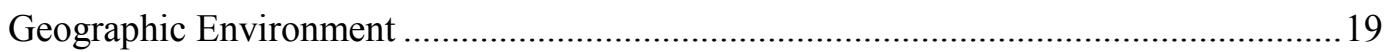

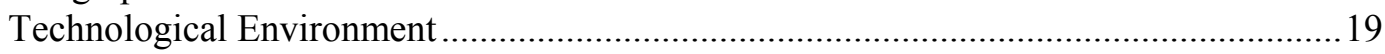

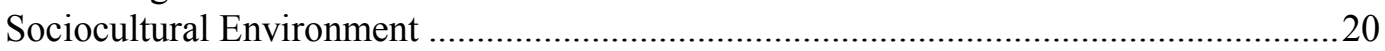

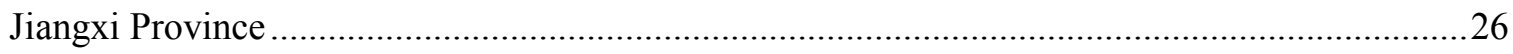

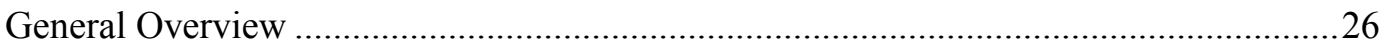

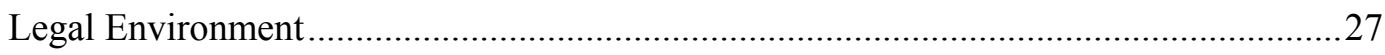

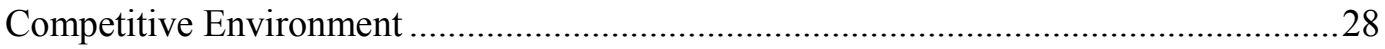

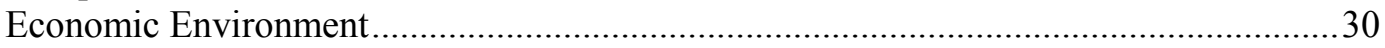

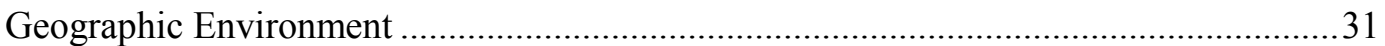

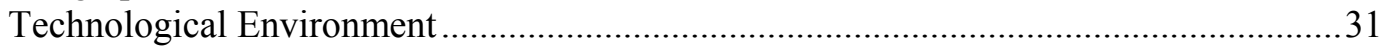

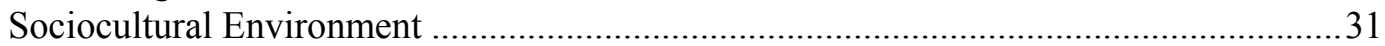

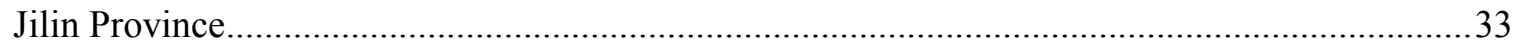

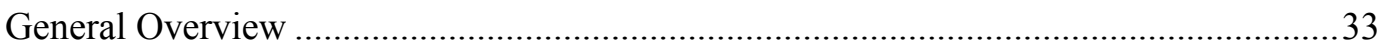

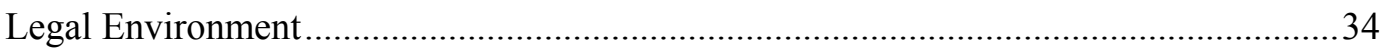

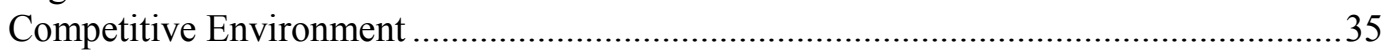

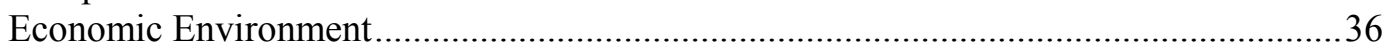

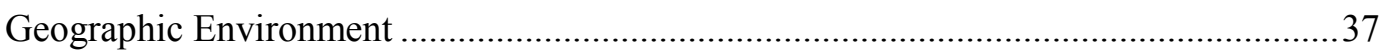

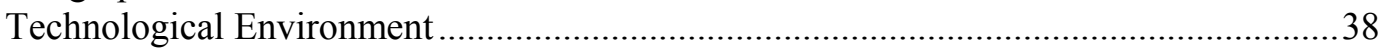

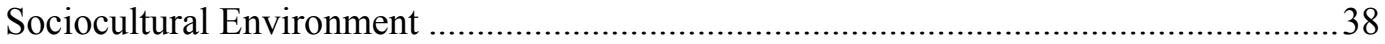

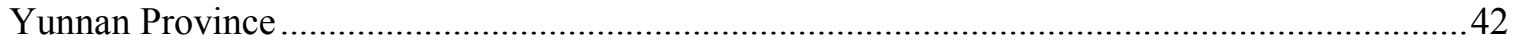

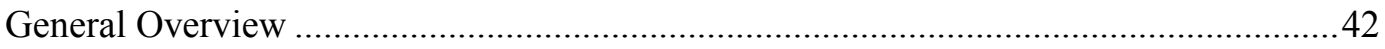

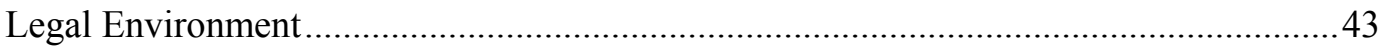

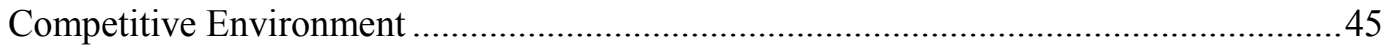

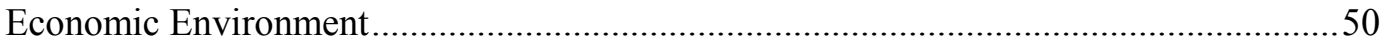

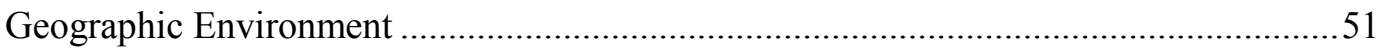

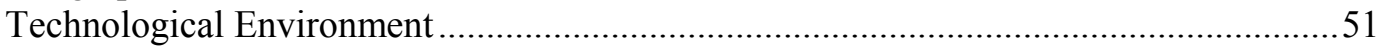

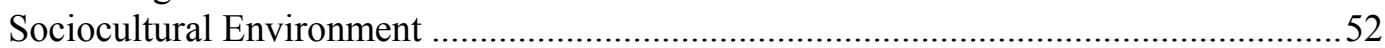




\section{Table of Contents (Continued)}

Appendices

A. Company Profiles

Beijing Companies

Guangdong Companies

Jiangxi Companies

Jilin Companies

Yunnan Companies

B. Guangdong Wind Measurement Statistics

C. Project Approval Procedure

Small Projects

Large Projects

D. Tied Aid and Foreign Assistance in China

E. Biomass Circulating Fluidized-Bed Gasifier Project

F. Outline of Rehai, Tengchong County Geothermal Field 


\section{List of Tables}

Page

Table $1 \quad$ Summary of Soft Loans Available to Chinese

Table 2 Wind Energy Potential of Off-Shore Islands and Areas Within $10 \mathrm{~km}$ Inland From the Coast of Fujian and Eastern Guangdong .............................................. 17

Table 3 Average Income and Cost of Living Per Capita in Guangdong in 1997................ 18

Table $4 \quad$ Breakdown of Power Sectors in Guangdong ........................................................ 19

Table 5 Average Income and Cost of Living Per Capita in Jiangxi in 1997....................... 30

Table $6 \quad$ Breakdown of Power Sectors in Jiangxi ........................................................

Table $7 \quad$ Average Income and Cost of Living Per Capita in Jilin ..................................... 37

Table $8 \quad$ Breakdown of Individual Power Sectors in Jilin ................................................. 37

Table $9 \quad$ Areas for Wind Farm Development in Jilin (Yearly Averages) ............................ 41

Table $10 \quad$ Known Geothermal Resources in Western Yunnan ..............................................

Table 11 Total Energy Potential of Top 24 Sites in Western Yunnan..................................

Table 12 Thermal Energy Resources of High-Temperature Water Systems in Tengchong... 47

Table 13 Average Income and Cost of Living Per Capita in Yunnan in 1997..................... 50

Table $14 \quad$ Breakdown of Power Sectors in Yunnan ............................................................ 


\section{Glossary}

$\begin{array}{ll}\text { BOOT } & \text { build-own-operate-tranfer } \\ \text { BOT } & \text { build-operate-transfer } \\ \text { CRED } & \text { Center for Renewable Energy Development } \\ \text { CO }_{2} & \text { carbon dioxide } \\ \text { DOE } & \text { U.S. Department of Energy } \\ \text { DWTM } & \text { Dali Wind Turbine Manufacturing Company } \\ \text { EJ } & \text { Exajoule }\left(10^{18} \text { J) }\right. \\ \text { ETC } & \text { Economic and Trade Commission } \\ \text { GDP } & \text { gross domestic product } \\ \text { GEF } & \text { Global Environment Facility } \\ \text { GSEE } & \text { Global Solar Energy Equipment Company } \\ \text { GW } & \text { gigawatt } \\ \text { ICUT } & \text { Industrial and Commercial Unification Tax } \\ \text { IMF } & \text { International Monetary Fund } \\ \text { IPP } & \text { Independent Power Producers } \\ \text { IP } & \text { intellectual property } \\ \text { JERI } & \text { Jilin Energy Resources Institute } \\ \text { JV } & \text { joint venture } \\ \text { KWh } & \text { kilwatt hour } \\ \text { KXSE } & \text { Kunming Xinying Solar Energy Facility Plant } \\ \text { MOA } & \text { Ministry of Agriculture } \\ \text { MOF } & \text { Ministry of Finance } \\ \text { MOFTEC } & \text { Ministry of Foreign Trade and Economic Cooperation } \\ \text { MOST } & \text { Ministry of Science and Technology } \\ \text { MW } & \text { megawatt } \\ \text { NREL } & \text { National Renewable Energy Laboratory } \\ \text { OECF } & \text { Overseas Economic Cooperation Fund, Japan } \\ \text { PPA } & \text { power purchase agreement } \\ \text { PV } & \text { photovoltaics } \\ \text { R\&D } & \text { research and development } \\ \text { RET } & \text { renewable energy technology } \\ \text { RMB } & \text { Renminbi (People's Money) } \\ \text { SDPC } & \text { State Development Planning Commission } \\ \text { SETC } & \text { State Economic and Trade Commission } \\ \text { SEZ } & \text { Special Economic Zone } \\ \text { SPC } & \text { State Power Corporation } \\ \text { SSTC } & \text { State Science and Technology Commission } \\ \text { STC } & \text { Science and Technology Commission } \\ \text { U.S. } & \text { United States } \\ \text { VAT } & \text { value-added tax } \\ \text { YGDC } & \text { Yunnan Geothermal Development Company } \\ & \end{array}$




\section{Introduction}

The People's Republic of China has undergone many changes over the past decade that have led to new growth and created opportunities for many industries, including the renewable energy industry. China has consistently had one of the fastest-growing economies in Asia, expanding an average of $11 \%$ between 1978 and 1993. This trend is expected to continue to 2020 at an annual average of $8 \%$ to $9.5 \%$. Energy use (principally coal), however, has caused very serious environmental problems including air pollution, acid rain, greenhouse gas emissions, and respiratory disease.

China has implemented several new laws affecting renewable energy, including the protection of intellectual property. Currently, the Chinese are streamlining the entire government structure and focusing on implementing and emphasizing a system run by the rule of law. Despite the current metamorphosis of China's legal system, more policies (including additional financial incentives) are necessary to ensure the continued rapid proliferation of renewable energy throughout the country.

Although there are vast opportunities in China, potential investors and businesspersons must consider all the risks as well. There is still a bias towards coal and other conventional sources of power because the initial capital costs to build a conventional power plant or to use conventional energy sources are relatively low. Financing for renewable energy projects, despite new outlets, is still a challenge to obtain. In addition, many regions are hard to access because of China's underdeveloped infrastructure. U.S. companies are often at a disadvantage because of strong competition from European and Japanese firms, which receive large subsidies from their governments.

The Chinese are extremely interested in developing their manufacturing base of renewable energy technologies (RETs). A few European firms are now in the process of establishing joint ventures with Chinese partners. As these new joint ventures become fully operational, importing and selling renewable energy products throughout the country will be become extremely difficult as new barriers will arise in order to protect domestic interests. Despite these problems, ignoring a market such as China would only make penetration into that country more difficult, if not impossible, in the future.

This market assessment is a continuation of a report done in 1997 that analyzed six provinces (Inner Mongolia, Gansu, Shandong, Qinghai, Xinjiang, and Zhejiang) in China. The information contained in this report comes mostly from interviews conducted with both central and local government officials, state and local power bureau officials, and various company executives. The report provides valuable market information necessary for any company interested in entering China's renewable energy market. It also details the legal, competitive, sociocultural, technological, geographic, and economic environments of four provinces in China - Guangdong, Jiangxi, Jilin, and Yunnan. In addition, it outlines the major central government policies and contacts important to renewable energy development within China. These four provinces are considered by the Chinese to be excellent markets for RETs. However, they are by no means the only provinces in China that have promise as markets for renewable energy technologies. 


\section{Chinese Central Government}

More often than not, a foreign businessperson will have to encounter one or more central government agencies in order to move a project along the approval process. In addition, the central government has set policies which affect all provinces and autonomous regions throughout the country. Therefore, it is extremely important to know what central government agencies, policies, and laws affect project development in China.

In May 1998, Chinese Premier Zhu Rongji announced a major restructuring of the Chinese government, eliminating 11 ministries. In addition, many departments within the surviving agencies were also deemed redundant and eliminated. Despite these major changes, those who were previously responsible for renewable energy development have continued their involvement in this area.

One major change has been that the Energy and Communication Department of the former State Planning Commission, now known as the State Development Planning Commission (SDPC), has been eliminated and that the former responsibilities of that department were moved to the Basic Industry Department of the SDPC. One division of the Basic Industry Department will be responsible for medium- and long-term energy policy. Below are the agencies involved with renewable energy development in China.

\section{Central Government Agencies Involved with Renewable Energy}

China's central government agencies that are participating in the development of renewable energy technology are as follows:

\section{Ministry of Agriculture (MOA)}

Main Contact: $\quad$ Bai Jinming, Division Chief of the Energy Division

Address: $\quad 11$ Nongzhanguan Nanli, 100026 Beijing, P.R. China

Telephone: $\quad$ (8610) 65003478

Fax: $\quad$ (8610) 65002448

The Environmental Protection and Energy Department in the Ministry of Agriculture has been terminated and only two divisions - the Energy and Biological Divisions - have been kept. The Energy Division, which is mainly in charge of rural environmental and electrification issues, grants 10 million Renminbi (RMB), or "People's Money" each year to support RET dissemination and demonstration projects. The Energy Division's main responsibilities are to analyze renewable energy use and promote sustainable development in the rural areas, with emphasis on biomass and solar/thermal technologies.

The MOA, like the SDPC and State Economic and Trade Commission (SETC), has a strong relationship with the U.S. Department of Energy (DOE). In February 1995, the two organizations signed an annex of technology cooperation to jointly promote biomass technology commercialization. 
Ministry of Science and Technology (MOST)

Main Contact: $\quad$ Li Baoshan, Deputy Division Chief of High and New Technology Development and Industrialization Department

Address: $\quad$ 15B Fuxing Road, 100862 Beijing, P.R. China

Telephone: $\quad$ (8610) 68512618 or 68515544 (ext. 1713)

Fax: $\quad$ (8610) 68515004 or 68512618

The Ministry of Science and Technology, formerly known as the State Science and Technology Commission (SSTC), manages national science and technology research projects. The High and New Technology Development and Industrialization Department is in charge of regulating and organizing science and RET projects. The MOST and SDPC jointly formulate the Five-Year Plan for science and technology. MOST also organizes and implements renewable energy research projects and promotes its technological institutions. In addition, MOST develops national policies regarding research of new and high-technology development and planning.

\section{Small Turbine Association}

Main Contact:

Qin Hesheng

Telephone:

Not yet confirmed; please contact the Center for Renewable Energy

Development (CRED) for further contact information.

Telephone:

Fax:

(8610) 69733110 or 69737074

(8610) 69733110

The organization has no government function. However, it has taken over the main functions of the Ministry of Machinery with regard to domestic manufacturing of small wind turbines. (The Ministry of Machinery was eliminated in the government restructuring.)

\section{State Development Planning Commission}

Main Contact:

Chen Heping, Division Chief of Energy Efficiency and Renewable Division of the Basic Industry Department

Alternate Contact: $\quad$ Zhou Huang

Address:

Telephone:

38 Yuetan Nanjie, 100824 Beijing, P.R. China

Fax:

(8610) 68502489

(8610) 68502728 or 68502489

The SDPC is a comprehensive economic management commission that formulates the National Economic Development Plan, the Five-Year Plan, and the National Long-Term Program. In addition, the organization approves all project investments.

The Basic Industry Department is responsible for drafting the state development strategy for energy, transportation, and raw materials. In addition to formulating long-term policies, the department will also monitor and analyze the status of basic industry development and spearhead all important national projects.

The Foreign Capital Utilization Department is responsible for approving joint ventures and foreignfunded projects in China, and for allowing Chinese currency to be converted into hard currency. 


\section{State Economic and Trade Commission}

Main Contact: $\quad$ Liu Hongpeng, Division Chief, Energy Division

Address:

26 Xuanwumen Xidajie, 100053 Beijing, P.R. China

Telephone:

(8610) 63045521

Fax:

(8610) 63045961

The SETC manages national economic operations, regulates enterprise operations, and approves technology transfer projects.

The Energy Division of the Energy Conservation and Comprehensive Utilization Department is responsible for formulating government energy conservation plans, comprehensive utilization, and renewable energy policies and regulations. This division also promotes new renewable energy and energy efficiency products and organizes environmental protection development and projects associated with environmental protection. In addition, the division controls millions of RMB to be used for loans towards renewable energy project development.

In October 1996, the SETC signed an annex with DOE outlining the cooperation between the two countries in bringing about the commercialization of renewable energy technologies throughout China.

\section{State Power Corporation (SPC)}

Main Contact: $\quad$ Zhang Yuan, Director

Alternate Contacts: $\quad$ Shi Pengfei, Director of New Energy Power Division

Address:

No. 137 Fuyou Street, 100031 Beijing, P.R. China

Telephone:

(8610) 63415095 or 66024928

Fax:

(8610) 66016077

The SPC is the primary entity responsible for administering all transmission and distribution of electricity in China. The company, which is state owned, is primarily concerned with large-scale, gridconnected power generation throughout the country. It also is very involved in formulating powerrelated policies for the central government. The SPC, for example, was directly involved with implementing policies related to encouraging wind farm development. In addition, the SPC coordinates most resource assessment activities.

\section{Central Government Policies and Regulations}

There are many central government policies and regulations that affect renewable energy development throughout the entire country. Some provinces do have their own incentives and laws in addition to these regulations. Many provinces use central government policies as their sole guidelines, however, even though many of these regulations are not strictly enforced and should not be seen as barriers to doing business in China. The following are some of the main regulations and policies that affect renewable energy development. 


\section{Criteria of New High-Technology Enterprises}

The SSTC has set the following criteria for new high-technology enterprises:

- The product must be listed in one of the 11 catalogues of products that the SSTC issues. (Renewable energy equipment is one of them.)

- The product must have good market potential both domestically and abroad. Annual revenue from the products and technology must be at least $50 \%$ of the total annual revenue of the venture.

- At least $30 \%$ of the total revenue must go towards research and development (R\&D) expenditures.

- At least $30 \%$ of the employees should have undergraduate degrees. At least $10 \%$ of the personnel should be involved in R\&D.

- The operation period of the enterprise should be more than 10 years.

\section{State Incentives to Promote New High-Technology Enterprises}

\section{Tax Incentives}

- Business Income Tax:

All joint ventures that have operation agreements of more than 10 years are exempt from state income tax for the first two profitable years. This tax exemption must first be approved by the tax administration. From the third to the fifth years of operation, the joint venture will only have to pay $50 \%$ of the required income tax. Local income tax can be waived during the first five years. After five years, if the product is still deemed advanced, the joint venture will only be responsible for paying $50 \%$ of the required state income tax.

Joint ventures established in remote and economically developing areas can continue to pay $15 \%-$ $30 \%$ less income tax for an additional 10 years after the fifth year of operation. However, this tax reduction must first get approval from the tax administration of the State Council.

Foreign investors of export-oriented enterprises do not need to pay income tax on money repatriated to their home country. If foreign investors reinvest their profits into the same business or into another business, and if the operation period is more than five years, the investor can qualify for a reimbursement of $40 \%$ of the income tax paid on the new investment. If this new enterprise is involved with advanced technology, $100 \%$ of this income tax can be reimbursed.

- Personal Income Tax Incentives:

All foreign employees who work in a joint venture enterprise and live in China for more than one year, are exempt from all income tax on income earned outside of China. The foreign employee also need only pay $50 \%$ of the personal income tax on his or her salary from the joint venture.

- Industrial and Commercial Unification Tax (ICUT) Incentives:

The following items can be waived from ICUT:

- Imported raw materials and spare parts for the purpose of export-oriented products

- Export products, except oil, and those products designated by the government 
- Imported equipment and materials that were financed with foreign-government loans or Bank of China loans.

In addition, a joint venture may reduce or waive ICUT, for a period of time, when the business starts operations or is experiencing financial difficulties.

\section{Tariff Incentives}

- All customs duties and value-added taxes (VAT) for imported wind turbines above 300 kilowatts $(\mathrm{kW})$ in size will be waived. Some provinces extend this policy to waiving or reducing the VAT for the power produced from these turbines.

- Import, export, and VAT tariffs for the production of high-technology products can be waived.

- The import permit can be waived for imported raw materials and spare parts used for producing products that will be exported.

- Imported equipment and materials that are financed with foreign-government loans or loans from the Bank of China do not have to pay any tariffs.

- All imported equipment, spare parts, and other materials that cannot be produced by domestic means are exempt from tariffs.

\section{Loan Incentives}

The Bank of China will give priority to those enterprises that engage in export-oriented business. In this case, priority means that the loans of such enterprises will be the first to be processed.

\section{Electricity Power Purchase Incentives}

The central government has made favorable policies in "China's Electricity Law" for purchasing power from renewable energy projects. The following provisions are stated:

- Provisions 5, 48: Renewable energy is strongly encouraged by the state.

- Provision 22: Stipulates that the state power utility, which is in charge of the local power grid, must purchase electricity generated by independent power producers (IPPs).

- Provision 36: Stipulates that the price paid for electricity should cover the cost to produce the electricity and that the returns should be reasonable in order to promote electric power development.

\section{Foreign Exchange Incentives}

On November 27, 1996, the People's Bank of China announced that China would accept Provision 8 of the Agreement of the International Monetary Fund (IMF). Beginning December 1, 1996, joint ventures were able to convert RMB into hard currency.

\section{Full Ownership}

The Chinese government permits $100 \%$ foreign ownership in industries that are not prohibited or restricted by the state. If the company is state owned, a foreign entity may only control as much as $49 \%$ of the venture. Nonetheless, the venture must be conducive to China's development and achieve high economic benefits. The company must also satisfy either of the following: 
- Use advanced technology and equipment, develop new products, be economical with respect to the use of raw materials and energy, upgrade and replace existing products, or manufacture products that can be exported.

- The value of the products it exports each year must account for more than $50 \%$ of the total value of all the products produced during the same year.

\section{Mandatory Ownership of Homes}

The Chinese government has, in the past, provided housing to all its citizens through the individual work units. However, a new policy implemented at the beginning of 1999 states that the government will no longer provide free housing anymore and that those who live in government housing have the option to buy the apartment in which they live.

The government will provide low-interest loans and subsidies and offer reasonable prices for the homes. This new policy, although it has little to do directly with renewable energy technologies, will have a significant impact on the marketing techniques that are currently used. No longer will companies be able to market their household products to government institutions for distribution. Product marketing will make the transition to the more traditional, Western style of reaching out to the individual homeowner. In addition, new distribution systems will need to be found. Already, many Chinese companies are finding new ways of distributing their products on a massive scale.

\section{Industries Closed to Private Companies}

Despite the economic transformation, many industries are still state-controlled and closed to private investors. Some of these industries are legally closed to foreign investors whereas others are restricted. Prohibited industries include the media, domestic commerce, foreign trade, insurance, postal service, telecommunications, and electricity transmission and distribution. Although these limitations still exist, there has been some indication that these restrictions placed on foreign involvement may be lifted to some extent.

\section{Guarantee Law}

Ensuring the validity and enforceability of security interests over real and moveable property has caused problems for financing power projects in China. Lenders and other project participants have faced the possibility that if the project fails, enforceability of security interests may be difficult to obtain despite explicit grants or contract agreements. The Guarantee Law is a uniform set of rules governing the taking and enforcing of security interests in real and personal property in China. This law has enhanced conditions for limited-recourse financing, while at the same time establishing a basic framework of rights, obligations, and remedies for secured parties and creditors.

The following five general types of security interests are covered under the law:

- Guarantees

- Mortgages (on both moveable and immoveable property)

- Liens

- Pledges

- Security over cash deposits. 


\section{Renewable Energy Development Program, 1996-2010}

The SDPC, SETC, and MOST have prepared a joint New and Renewable Energy Development Program that outlines the Chinese government's new commitment towards the development of clean energy sources. The objectives of the program are to raise the conversion efficiency of renewable energy and strengthen the contribution renewables offer to the total energy scheme. The program will be implemented in two stages:

1. From now until 2000, the focus will be on creating the modern industrial base and infrastructure necessary for the production of mature technologies such as wind and solar photovoltaic (PV) systems for homes and small communities. Research and demonstration projects will be done in order to expedite the maturity of other renewable energy technologies.

2. From 2001-2010, new technology development will reach the level of other industrialized nations.

The main tasks for each technology are as follows:

- Small hydro: Continue development so that installed capacity increases to 20 gigawatts (GW) by 2000 and $28 \mathrm{GW}$ by 2010.

- Wind power: Market small-scale wind turbines and improve their performance; develop local production capacity for wind turbines above $200 \mathrm{~kW}$; develop wind power control and management systems; strengthen the capacity for wind measurement, planning, siting, and designing; and, finally, construct 1,000 megawatts (MW) of large-scale wind farms by 2000 and 3,000 MW by 2010.

- Solar/PV power: Efficiency will be improved and system costs will be reduced through the development of low-cost solar cells and associated equipment. By 2000, PV power stations will be built in nine counties in Tibet. Small PV systems should be promoted so that the electricity needs of 28 counties, 10,000 townships, and 1,000 islands will be met. Distributed and centralized MW-scale PV power stations connected to the grids should be demonstrated.

- Geothermal energy: Actively exploit regions with high-temperature resources, while solving the problem of geothermal corrosion and water recharge. The use of heat pumps will be encouraged.

- Biomass: Plans for biomass power stations of $50 \mathrm{MW}$ or more to be built by 2000, using rice husks, wood scraps, and bagasse. $300 \mathrm{MW}$ will be installed by 2010. Biogas for power plants is not included in this scheme.

\section{Potential Obstacles}

\section{Financing}

- According to both the American Embassy and the SPC, the main obstacle to the development of renewable energy is lack of investment dollars.

- The SPC encourages domestic investment as well as foreign investment mechanisms such as buildown-operate-transfer (BOOT), build-operate-transfer (BOT), and joint ventures.

- China gives very few incentives to encourage foreign investment in power projects in China.

- The State Development Planning Commission, the Ministry of Science and Technology, and the State Economic and Trade Commission are doing a joint study on incentives for renewable energy in China. 
- There is a high degree of confusion with regard to financing.

- Past investors have submitted cost estimates to the SDPC for approval of potential projects.

- The SDPC would approve these projects, only to find out that these estimates were very low because the investors did not originally include financing for some of the equipment needed to complete the project.

- Now, the SDPC wants to take a second look at the figures for equipment financing and, in some cases, wants to reopen the projects for competitive bidding and start the entire process all over again.

\section{Small U.S. Companies with Limited Resources}

- It takes too many man-hours to scour a huge country such as China for potential business and to understand the process of getting a project developed in China. There are two ways to combat this dilemma. First, there is a program sponsored by the U.S. Department of Commerce that provides matching funds to establish a local trade organization to give the industry an in-country presence. Second, find a reliable agent to represent one's project in China. This agent must also have something to gain if the project succeeds.

\section{European Competition}

- Nearly all wind farms and many other renewable energy projects have grants or soft loans attached to them.

- European governments are quite happy to pay this money.

- European renewable energy companies receive a large amount of benefits through the grants and tied-aid packages that the European countries give to China.

(Please refer to chart in Appendix D.)

\section{Project Approval Process}

The current project approval process is outlined in Appendix C. This process, because of the change in the government structure, is expected to change in the near future. One change is the elimination of the Ministry of Electric Power. The State Power Corporation (SPC) should approve any power project.

If the project is a foreign joint venture, the International Financial Agencies Department of the Ministry of Finance (MOF) will be responsible for functions previously performed by the Ministry of Foreign Trade and Economic Cooperation (MOFTEC). The following are some guidelines for obtaining project approval:

- Getting a project approved takes plenty of perseverance and patience.

- For construction projects valued at less than \$30 million (U.S.), local State Development Planning Commission approval is needed.

- For renovation projects valued at less than \$50 million (U.S.), local State Economic and Trade Commission approval is needed.

- If any foreign capital is needed for the above projects, the total amount needs to be reported to the SDPC, but the project can be approved by the provincial authorities.

- For construction projects valued at more than $\$ 30$ million (U.S.) and renovation projects valued at more than $\$ 50$ million (U.S.), the extra step of State approval is needed.

- If the project is valued at more than 200 million RMB, the project needs State Council approval. 
- Special projects (such as the Three Gorges project) must be approved by the People's Congress. (Please refer to Appendix C.)

\section{Lack of Incentives for Renewables}

- New incentives are currently being considered at the central government level, yet more incentives are still needed to meet current demand and to compete with conventional resources.

- Many provinces do offer their own incentives to promote specific types of renewable energy technologies (primarily wind and PV). However, these incentives are not uniform throughout the country and must be researched within each province before the initial phase of a project.

\section{RMB Yuan Convertibility}

- There has been some relaxation of the foreign exchange policy and foreign companies are now allowed to freely convert some of their money into hard currency. China has relaxed controls on foreign exchange under the current account with regard to trade, labor, and tourism.

- There still is tight control, however, on all foreign investments and capital accounts, including direct investment, international loans, and securities trading.

- China announced a new regulation which stipulates that all foreign exchange transactions be done through the banking system.

\section{Invisible Cap on Returns}

- Profits are usually limited to $15 \%$.

- There are ways of getting around this invisible cap, but that usually involves longer waiting and more bureaucracy.

\section{Lack of Legal Recourse}

In the past, foreign businesses have been concerned over the lack of legal recourse in China. Although the legal structure has its problems, the central government is vigorously taking measures to protect the rights and property of both foreign and domestic business interests. President Jiang Zemin has taken steps such as forbidding the military to be involved in commerce, restructuring the legal educational system to focus on the rule of law, and phasing out judges without legal education. The following, however, outlines some of the concerns of businesses:

- There are few laws that protect businesspeople from certain improprieties.

- The few laws that are designed to protect both the foreign entity and the domestic entity are difficult to enforce.

- Many companies, from a variety of different industries, have found that negotiations do not stop with the signing of a contract. This has caused very tense moments and has stalled many projects from moving forward.

- The lack of intellectual property (IP) protection has prevented many companies from entering China and establishing joint ventures with Chinese manufacturers. 


\title{
Guangdong Province
}

\section{General Overview}

Guangdong Province is probably one of the most developed and progressive areas in China. Situated near Hong Kong, it naturally became one of the first Special Economic Zones (SEZs) and was allowed to develop faster than most regions of the country. Because of this rapid economic expansion, the province's infrastructure is among the most advanced in all of China. The province boasts both heavy industry and large-scale agricultural production. Therefore, its energy demand is one of the highest, if not the highest, in China. Currently, the total installed capacity is about $26.3 \mathrm{GW}$. Of this capacity, 4.8 GW comes from hydropower, $19.7 \mathrm{GW}$ from coal-fired power, and the remaining capacity from nuclear power and other sources.

The total population of Guangdong is 70 million, of which 50 million live in rural areas. The majority of the population already has access to electricity. As a matter of fact, the local government believes it would be easier and more economical to simply relocate the unelectrified population to areas near the grid than to use stand-alone systems or grid extension.

Renewable energy resources are relatively abundant in the province. Because Guangdong has a large agricultural industry, its biomass resource is plentiful. Guangdong also is rich in wind, solar, and some geothermal resources. However, most of the rivers and other hydro resources have already been exploited and Guangdong's supply of natural resources such as coal, gas, and oil are low. Last year, the total amount of coal consumed was about 400 million tons; more than 100 million tons of oil was consumed. Eighty percent of all this coal was imported from other provinces, thus making energy produced from coal plants relatively expensive. Despite this, very little of Guangdong's renewable energy resources have been used for energy production.

In the $1980 \mathrm{~s}$, more than $60 \%$ of the rural population used biomass material as their main source of fuel. Now, because of rising incomes and the low efficiency of directly burning straw and other agricultural material, only $40 \%$ of the rural population burns straw for energy. Today, more conventional plants are being built and less biomass material is being consumed. This rising demand for conventional energy in the rural areas combined with the continuing rapid development of the urban areas has created a large gap between supply and demand and has led to energy shortages. The provincial government has been seeking alternatives to alleviate this shortage while simultaneously becoming more self-reliant on its provincial resources for energy production. This has led to new policies and plans for renewable energy development in Guangdong.

\section{Major Governmental Institutions Involved with Renewable Energy Development}

The major government agencies that are involved with renewable energy development are:

\author{
Guangdong Provincial Agricultural Bureau \\ Main Contact: $\quad$ Chen Zhenghui, Director, Rural Energy Office \\ Telephone: $\quad$ (8620) 87729104 \\ Fax: $\quad$ (8620) 87643654
}

This organization is mainly responsible for rural energy issues. 


\section{Guangdong Provincial Economic Committee, Energy Division}

Main Contact:

Ou De Kai, Division Chief

Address:

305 Middle Deng Feng Road, 510031 Guangzhou, Guangdong, P.R. China

Telephone:

(8620) 83335847

Fax:

(8620) 83333805

\section{Guangdong Electric Power Bureau}

Main Contact: $\quad$ Huang Gou Qing, Engineer, Foreign Affairs Deptartment

Telephone: $\quad$ (8620) 87767888

Fax: $\quad$ (8620) 87778114

This organization is responsible for all power purchase agreements, transmission and distribution, and energy development.

Guangdong Provincial Planning Commission

Main Contact: $\quad$ Li Ya Xiang, Division Director

Telephone: $\quad$ (8620) 83133151

Fax: $\quad$ (8620) 83344483

Although the former Energy Department was eliminated, the local planning commission is still involved with energy development.

Other important agencies and semiprivate companies include the following:

Guangzhou Institute of Energy Conversion

Main Contact: $\quad$ Gao Xiangfan, Vice-Director

Telephone: $\quad$ (8620) 87606980

Fax: $\quad$ (8620) 87779767

This institute is under the direction of the Chinese Academy of Sciences and has departments for hydro, biomass, geothermal, clean fuels, and other renewables.

\section{Guangzhou Research Institute for Utilization of Reclaimed Resources}

Main Contact: $\quad$ Li Xing Ru, Director, Senior Engineer

Telephone: $\quad$ (8620) 86627834

Guangdong Wind Power Company, Ltd.

Main Contact: $\quad$ Cheng Feng Pan, General Manager

Telephone: $\quad$ (8620) 87767888 ext. 23228

Fax: $\quad$ (8620) 87302625

This organization is responsible for all wind power development in Guangdong. 


\section{Legal Environment}

\section{Responsibilities of Various Agencies}

Like the rest of the country, the local government is undergoing reform. This has led to uncertainty with regard to the responsibilities of the various agencies and the departments within them. However, one should assume that things are status quo until notified otherwise. Different agencies are responsible for different aspects of the energy industry. For example, the Provincial Planning Commission is responsible for general planning for energy development. The Provincial Economic Commission is responsible for transportation, production, and plan administration. In addition to those responsibilities, the local economic commission handles all affairs having to do with energy conservation and comprehensive energy utilization. Finally, the Agricultural Bureau is responsible for all issues involving rural energy.

\section{Incentives to Use Renewable Energy}

Guangdong does not have a plethora of incentives (in addition to those implemented by the central government) that would encourage the rapid development of renewable energy. However, as more and more studies have outlined the potential resources of renewable energy, the local government has taken notice and has begun to implement new policies encouraging their development. In addition to these incentives, there are also regulations designed to stem the amount of pollution that is emitted into the environment. Because renewable energy is nonpolluting, these regulations can be seen as indirect incentives to the development of renewable energy in the province.

In March 1998, the Guangdong Government issued a list of industrial sectors that would have beneficial policies to encourage the development of renewable resources. Wind energy was one of the main beneficiaries of these policies. When it was shown that there was a potential capacity for as much as 7,000 MW of wind sites, the provincial government instituted the following policies to attract investors to develop wind power in Guangdong:

\section{Land-Use Benefit}

The land used to develop wind farms can be used at reduced rates for the entire period of construction and operation. The amount of land that qualifies for this benefit only includes the area on which the turbines are built, not the surrounding land.

\section{VAT Reduction on Wind Energy}

The VAT on all electricity produced and sold by a wind farm has been reduced from the normal $17 \%$ to $6 \%$.

\section{Higher Prices for Wind Power}

Guangdong's energy prices are typically higher than those in the rest of the country; prices paid for wind energy are usually higher depending on the location of the wind farm. The prices paid by the power bureau are usually between 0.7 and 1.0 RMB/kilowatt-hour $(\mathrm{kWh})(\$ 0.09-\$ 0.13 / \mathrm{kWh}$ U.S.). 


\section{Regulations and Incentives to Discourage Pollution}

\section{Moratorium on New Thermal Plants on Pearl River Delta}

The government issued a moratorium on all new thermal power plants built near the Pearl River Delta because there was too much pollution in the area. This has led planners to seek alternatives for energy development. The plan is to use nuclear power, natural gas, and wind power as the main resources for that region.

\section{Document No. 36}

In 1994, the local Economic and Trade Commission issued Document No. 36 on behalf of the State Council. According to this document, a list of special industrial sectors (such as those that engage in the comprehensive utilization of natural resources) will receive special incentives. For example, if there is a sugar mill that uses the waste of refining to make particleboard or other products, the VAT on particleboard would only be $4 \%$ as opposed to the standard $17 \%$. The companies would initially pay the $17 \%$ tax, but would get the difference refunded directly from the tax bureau at the end of the year. Enterprises that engage in the collection and utilization of waste can share in this beneficial policy. In addition, these enterprises, depending on the industrial sector, are exempt from paying income taxes for anywhere between one and five years.

\section{Closure of All Polluting Agricultural Industries}

Earlier this year, the Guangdong Government introduced a regulation that stated that all industries that produce a certain amount of pollution in agricultural areas should be closed. This regulation has created a trend of treating pig waste on pig farms to produce biogas for energy production in order to avoid fines and possible closure.

\section{Competitive Environment}

\section{Overview of Renewable Energy Technologies}

\section{Bioenergy and Biomass Utilization}

Guangdong has abundant sources of biomass. The province produces approximately 600 million tons of biomass per year, the majority of which is located in Zhanjiang County. The latter has 33 sugar mills, or approximately $60 \%$ of the total number of sugar mills in the province.

Traditionally, most biomass has been used directly for cooking and heat. However, because the energy conversion of directly burning biomass was under $20 \%$, this was seen as an inefficient way of utilizing the resource. This led to alternative, more efficient ways of using biomass. Various research organizations under the provincial government have been involved in several different projects to produce bagasse from sugarcane, rice husks, and urban waste. This resource is primarily used for local heating, cooking, and electrification. However, in many cases, it is more profitable for the sugar mill to use the bagasse to manufacture other products such as compressed wood or particleboard. 
In most cases, the heat and electricity produced from bagasse is consumed by the mill itself. The remaining electricity is then sold back to the utility. However, the remaining energy is usually less than $10 \%-20 \%$ of the total production.

\section{Straw Surplus}

As the economy in Guangdong becomes more and more developed, less and less biomass is being consumed there. This is especially true in the rural areas, where biomass was the main source of household fuel. This has caused several problems in the rural areas. Because less straw is being burned for fuel, it is either rotting or being burned wastefully, which has contributed to a variety of natural disasters such as wildfires. The government is hoping that this surplus straw can either be converted to liquefied gas or made into briquettes for cooking and heating. Unfortunately, the Chinese lack both the technology and investment for liquefying the straw and so the wasteful burning continues.

\section{Centralization of Pig Farms}

Another trend in Guangdong is the centralization of pig farms. In the past, rural farmers used to raise several pigs on a small scale. If the waste was recycled to produce energy, it was used in a single household mainly for cooking and heating. This was later determined to be inefficient and a poor use of the animal waste. Because many pig farms were under the threat of fines and closure, many farms began to consolidate. This consolidation centralized the pig waste so that it could be used to produce biogas for electricity and heating fuel on an industrial scale. Currently, there are more than 100 of these pig farms in Guangdong. Centralizing pig farms and converting the waste for energy production has shown to be an economical way of producing energy for the use of the agricultural community. Biogas/diesel hybrids have produced energy at $0.35 \mathrm{RMB} / \mathrm{kWh}(\$ 0.04 / \mathrm{kWh}$ U.S.). In one case, the waste of up to $100,000 \mathrm{pigs}$ was treated and converted into fuel. Unfortunately, the largest obstacle to developing more of these types of farms is the lack of funding.

\section{Urban Waste}

Currently, the Chinese are experimenting using urban waste for a variety of different applications, mostly cooking and heating. However, it is hoped that urban-waste facilities will eventually be large enough to produce electricity.

Guangdong has five domestic companies that deal with urban waste. In addition to these, there are two foreign companies (from Canada and Finland). The Canadian company has entered into a joint venture with a Chinese firm in Shenzen; negotiations are still under way between the Chinese and the Finnish company in Zhuhai. Such activities suggest that there is indeed a market. Unfortunately, the size of the market in Guangdong was unknown to those who were interviewed for this paper.

\section{Geothermal Utilization}

Guangdong has more than 200 geothermal sites. Of these sites, more than 30 have temperatures over $80^{\circ} \mathrm{C}$. The Chinese concluded that the best way to use this resource is for direct heating, tourism, crop drying, and fish farming. The Guangzhou Institute of Energy Conservation had spent many years researching low-heat thermal geothermal facilities, but decided that it was uneconomical for them to generate electricity at temperatures below $100^{\circ} \mathrm{C}$. During their years of research, three power stations were built. These included one $26-\mathrm{kW}$ unit using a $91{ }^{\circ} \mathrm{C}$ source built in the $1970 \mathrm{~s}$, one $300-\mathrm{kW}$ unit using a binary cycle, and a third, 300-kW grid-connected unit, built in the early 1980s.

Although the known geothermal resources are not hot enough to generate electricity, there is a belief that there could be sufficiently hot resources near the Pearl River Delta because of the many fault lines in the 
area. Exploration of this area has been hindered due to the lack of financial resources. In addition to the Pearl River Delta, there is an area near Macau that has a resource of $100^{\circ} \mathrm{C}$ at a depth of 100 meters. Here, the Chinese plan to build a multipurpose facility that would be used for heat and possibly electricity production.

\section{Hydropower Utilization}

Hydropower is one of the main power sources for Guangdong Province. However, the government has not put much emphasis on its development because most of the rivers in the province have already been exploited. Currently, there is about 6,600 MW of installed hydropower in Guangdong, with very few plans for installing additional capacity. Most of the central government's financial resources are going into the Three Gorges Project. Some of this project's electricity will be exported to Guangdong, eliminating the need for new capacity to be built within the province.

Micro-hydro development is proceeding very rapidly in the rural areas. Unfortunately, the Water Resource Bureau, which is responsible for micro-hydro development, did not have any current statistics to support this statement. Government officials were unable to list the names of the small and microhydro turbine manufacturers in Guangdong; however, they were able to estimate that there were close to 26 manufacturers that made small or micro-hydro turbines. These firms do not specialize in manufacturing hydro equipment; rather, they manufacture these turbines in addition to other products.

\section{Solar Power Utilization}

Solar radiation in Guangdong Province is relatively low and ranges between 1,400 and 2,000 hours per year. Therefore, the use of photovoltaics is practically nonexistent. When PV is used, it is primarily for communication purposes on tall buildings. Solar thermal technologies such as solar water heaters are used as well as solar chillers for cooling and ice making. There are about 10 solar water heater enterprises in Guangdong. However, only one or two dominate the provincial market.

\section{Solar Water Heater Market}

The solar water heater market is growing amongst the rural population. However, it still must compete with liquefied gas. The average price of solar water heaters is about $1,000 \mathrm{RMB} / \mathrm{m}^{2}\left(\$ 121.50 / \mathrm{m}^{2} \mathrm{U} . \mathrm{S}\right.$.), whereas $15 \mathrm{~kg}$ of liquefied gas costs only $50 \mathrm{RMB}(\$ 6.08 \mathrm{U} . \mathrm{S}$.) and lasts about two months. Most of this gas is imported from the Middle East via Hong Kong and probably receives indirect subsidies.

\section{Wind Power Utilization}

There is basically only one company involved in wind energy development in Guangdong, the Guangdong Wind Power Company, Ltd. Although many in the Guangdong government believe that about 7,000 MW of wind energy can be developed along the province's coastal areas and its off-shore islands, a study done by the U.S. National Renewable Energy Laboratory (NREL) indicated that the potential for wind power development is much greater. Despite this, very little of the province's wind resource has been exploited. This is due primarily to the provincial government's requirement that all turbine purchases have foreign soft loans or tied aid attached to them. (Please refer to Appendix D for tied aid associated with individual wind projects.) The table below provides a brief overview of the kinds of soft loans available to the Chinese. 
Table 1. Summary of Soft Loans Available to Chinese

\begin{tabular}{|l|c|c|}
\hline \multicolumn{1}{|c|}{ Country Offering Loan } & Interest Rate & Term \\
\hline \hline Denmark & $0 \%-2.5 \%$ & $12-15$ years \\
\hline Spain & Less than $3 \%$ & 40 years, 10 -yr. grace period \\
\hline The Netherlands & $0 \%$ & $12-15$ years \\
\hline Germany & $0.75 \%$ & $10-40$ years \\
\hline Japan & In negotiations w/ Chinese & N/A \\
\hline
\end{tabular}

Source: Zhang Yuan, State Power Corporation

However, after all the recent resource assessment activities (see Table 2), the government now realizes wind's potential and has started aggressively recommending and implementing policies to encourage its development.

Table 2. Wind Energy Potential of Off-Shore Islands and Areas within $10 \mathrm{~km}$ Inland from the Coast of Fujian and Eastern Guangdong

\begin{tabular}{|l|c|c|c|c|}
\hline Resource & $\begin{array}{c}\text { Average Wind Power } \\
\text { Density } \mathbf{a} \mathbf{3 0} \text { m heights } \\
\left(\mathbf{W} / \mathbf{m}^{\mathbf{2}}\right)\end{array}$ & $\begin{array}{c}\text { Total Windy } \\
\text { Land Area } \mathbf{( k m}^{\mathbf{2}} \mathbf{)}\end{array}$ & $\begin{array}{c}\text { Total Installed } \\
\text { Capacity } \\
(\mathbf{M W})\end{array}$ & $\begin{array}{c}\text { Net Energy } \\
\text { Potential } \\
(\mathbf{G W h} / \mathbf{y r})\end{array}$ \\
\hline \hline Moderate & $200-300$ & 3,047 & 21,116 & 36,709 \\
\hline Good & $300-400$ & 1,716 & 11,897 & 26,631 \\
\hline & $400-500$ & 961 & 6,660 & 17,541 \\
\hline Excellent & $500-700$ & 878 & 6,085 & 18,608 \\
\hline & $700-1000$ & 228 & 1,580 & 5,364 \\
\hline Total & & $\mathbf{6 , 8 3 0}$ & $\mathbf{4 7 , 3 3 8}$ & $\mathbf{1 0 4 , 8 5 3}$ \\
\hline
\end{tabular}

Source: Dennis Elliott, National Renewable Energy Laboratory

Wind power is very promising in Guangdong Province for the following reasons:

- The province lacks conventional energy resources.

- The province has some of the highest electricity prices in the country.

- The province is continuing to experience very fast economic growth and can provide many opportunities for investment.

- The province has abundant wind energy resources along its coastal areas (see Appendix B).

BOT Wind Farm on Nan 'Ao Island, Guangdong

Reliance on foreign soft loans will not diminish any time soon. However, as technological improvements are made and larger wind farms are built, full-scale commercialization will occur. Indeed, commercial wind farms have already started coming to fruition. For example, the Dutch developer NUON entered into a BOT agreement with the local utility on Nan 'Ao Island to build and operate a 24-MW wind farm (which became operational in June 1998) for 20 years. The power purchase agreement (PPA) was structured so that NUON would get $\$ 0.065 / \mathrm{kWh}$ U.S. during the first year. During the next 10 years, the price of energy will be indexed $3 \%$ annually. In year 11 , the price will go back down to $\$ 0.06 / \mathrm{kWh}$ U.S. and rise 3\% annually for the next 10 years. This is the first time the Chinese government has allowed a utility to enter into a PPA for a wind farm that stipulates payment in hard currency and indexing of the price of energy to a foreign entity. 


\section{Economic Environment}

Guangdong Province is one of the most developed areas in all of China. It is one of the few areas in China that contains both strong agricultural and industrial bases. The southern part of the province contains most of the heavy industry such as steel, chemicals, and other large manufacturing facilities.

The main agricultural product grown in Guangdong is rice. Sugar is grown in the western part whereas fruit and tea are grown in the mountainous northern region. Despite the vast agricultural resources, the wealthiest rural inhabitants get most of their disposable income from other sources such as small businesses or the industrial sector, which sets up enterprises locally.

Because of the diversity of the region, incomes vary significantly throughout the province. The industrial regions in the south have the highest per capita incomes with more than 8,000 RMB per year ( $\$ 972.00$ U.S.). However, in some of the poorest counties, located in the western and northern parts of the province, incomes drop well below 2,000 RMB per year (\$240.00 U.S.) (see Table 3). It is these poor, rural areas that would require government subsidies for renewable energy systems.

\section{Brightness Program}

The central government sponsors the "Brightness Program," in which the government provides small subsidies of approximately 200 RMB (\$24.00 U.S.) per household for small renewable energy systems to provide electricity to those living in unelectrified areas. However, most regions in Guangdong already have access to the grid, making stand-alone electrical systems redundant. The provincial government has indicated that it would be easier and more cost effective to relocate the people who live in the few unelectrified areas rather than providing individual renewable energy systems for these households.

Table 3. Average Income and Cost of Living Per Capita in Guangdong in 1997

\begin{tabular}{|l|c|c|c|}
\hline \multicolumn{1}{|c|}{ Location } & $\begin{array}{c}\text { Average Net Income } \\
\text { (\$/year U.S.) }\end{array}$ & $\begin{array}{c}\text { Average Cost of Living } \\
\text { (\$/year U.S.) }\end{array}$ & $\begin{array}{c}\text { Registered } \\
\text { Unemployment }\end{array}$ \\
\hline \hline Urban Area & 8,116 & 6,737 & $3,340,000$ (total) \\
\hline Rural Area & 2,000 & & \\
\hline
\end{tabular}

Source: Center for Renewable Energy Development

\section{Cost of Electricity}

In most situations in China, industry pays more for electricity. This is the case in Guangdong. The reasoning behind this is that industry has more ability to pay higher prices for energy. This situation is unlike that in most Western nations, where industry is able to negotiate a lower price for its energy because of the larger quantities used. However, from a developer's standpoint, this is beneficial because industrial users consume the most amount of energy. In addition, the local power bureau is willing to pay more for energy produced from renewable energy sources.

\section{Energy Price and Consumption in Guangdong}

Residential users pay some of the highest prices for electricity in China, averaging 0.6-0.8 RMB $/ \mathrm{kWh}$ (\$0.075-\$0.10/kWh U.S.). In some suburban areas, the price can escalate dramatically, reaching $3 \mathrm{RMB} / \mathrm{kWh}(\$ 0.375 / \mathrm{kWh}$ U.S.). This situation has caused some concern for local government officials, 
and an investigation is being conducted by the Price Bureau, the local Economic Commission, and the utility. The Guangdong People's Congress submitted a request to these agencies to put a price ceiling on suburban power prices in order to bring them in line with prices paid in the urban areas.

Industry consumes the greatest amount of energy in Guangdong (approximately 66\% of Guangdong's total energy consumption). Table 4 breaks down the consumption levels by sector.

Table 4. Breakdown of Power Sectors in Guangdong

\begin{tabular}{|l|c|c|}
\hline \multicolumn{1}{|c|}{ Sector } & $\begin{array}{c}\text { Power Consumption/Year } \\
\text { (million tce) }\end{array}$ & Power Price (\$/kWh U.S.) \\
\hline \hline Agricultural & 3.49 & $0.075-0.10$ \\
\hline Industrial & 46.27 & $0.125-<0.125$ \\
\hline Institutional & 10.93 & $0.075-0.10$ \\
\hline Residential & 9.9 & $0.075-0.10$ \\
\hline
\end{tabular}

Source: Guangdong Power Bureau

\section{Geographic Environment}

Guangdong is located on the southeastern coast of China. The climate is considered to be subtropical. The southern coastal area contains some of the busiest ports in the country and is easily accessible from Hong Kong. The coastal regions are often hit with typhoons from August through October. However, the southern coast typically has weaker average wind speeds, making it less than ideal for wind farm development. The eastern coast of the province, however, has excellent resources and the topography in that region is good for development because there are low-lying, rolling hills easily accessible by paved or dirt roads.

The northern area of Guangdong is mountainous and sparsely populated, whereas the southwestern area consists of flat agricultural fields.

\section{Technological Environment}

Guangdong is one of the most advanced provinces in China. It has an excellent infrastructure consisting of a network of railway, airports, seaports, and superhighways. In addition, it has a relatively strong power grid that can sustain intermittent energy sources such as wind. The local and county governments are continually upgrading the infrastructure and more plans are under way to develop new roads, bridges, and power plants.

The province boasts some of the busiest ports in China. Zhanjiang City, for example, contains China's fifth largest port. This port has easy access to both Hong Kong and the western part of China. The city government has submitted plans for new highways, bridges, and industrial facilities, as well as a 200-MW wind farm.

Most hotels and research centers have access to relatively new computer equipment and software. Software for highly technical operations is also easily developed in Guangdong. In addition, telephone communications are world class. Cellular phones and e-mail are almost as common in the larger cities, such as Guangzhou, as they are in Los Angeles. 
The main problem for Guangdong, as in much of China, is state-of-the-art renewable energy technology and production lines. Guangdong, despite its status as a highly developed province, must import this technology in order to establish any kind of competitive products for the international market.

\title{
Sociocultural Environment
}

The rapid development of Guangdong's economy has also made the residents of Guangdong keenly aware of the environmental degradation that often comes as a by-product. Indeed, the well-educated, urban population often voices its concerns regarding the environment. However, this concern has trickled down to the poorer, rural population as well. More and more people are becoming accustomed to integrating energy conservation issues into their daily lives. For example, "green" lights and energyefficient stoves are becoming more and more popular.

Many industries in both the urban and rural areas have implemented procedures aimed at stemming further environmental damage. Many sugar mills, such as those at Feng Shou and Suixi Beipo, have used much of the waste of processing one product to create another product. There are entire research facilities devoted to recycling and to the comprehensive uses of industrial waste. In addition, industries are constantly looking for technologies to reduce the emissions created by their production processes.

Despite the concern for the environment, the utility bases its criteria for purchasing and developing power on two principal factors. These are the price of electricity and the amount of power that can be produced by the power plant. In other words, the utility is willing to buy renewable energy at a higher price as long as there is not too much energy produced by that power plant. Of course, the utility would be more willing to buy wind power from the Guangdong Wind Power Company than from a wholly owned foreign entity. Therefore, forming a partnership with this company could prove beneficial for potential developers entering this market.

\section{Renewable Energy Company Profiles}

\author{
Guangdong Wind Power Company, Ltd. \\ Main Contact: $\quad$ Chen Feng Pan, General Manager \\ Address: $\quad 757$ Dongfeng Road E., 510600, Guangzhou, P.R. China \\ Telephone: $\quad$ 8620/87767888 (ext. 23228) \\ Fax: $\quad 8620 / 87302625$
}

The Guangdong Wind Power Company has a virtual monopoly on wind power development in that province. It registered as a corporation in May 1997 with an initial investment of 20 million RMB (about \$2.4 million U.S.). The company, like many in China, is a limited partnership. Despite its limited status, it is still a state-owned company. The company has three shareholders and a majority (55\%) is controlled by the Guangdong Power Bureau. The remainder of the company is held by a company under the Provincial Planning Commission (20\%) and the State Energy Conservation and Investment Company $(25 \%)$.

The company's main emphasis is wind farm development. However, it also offers consulting services and manufactures peripheral equipment such as towers. Currently, the company is following a plan to develop wind sites along the eastern coast of the province. By the year 2000, company officials hope to develop between 50 and $100 \mathrm{MW}$. 


\section{Wind Power Projects Open to Foreign Investment and Partnership}

Guangdong Wind Power has several projects in various stages of planning. They include the following:

\section{Huilai Project}

The one that is farthest along is the Huilai Project. Currently under construction, it will consist of 20 $600-\mathrm{kW}$ turbines. The entire financing package consists of 50\% soft loans from the German government and $50 \%$ from commercial banks. The soft-loan component has an interest rate of $0.75 \%$ over a 25 -year term. The commercial component of the financing package is $7 \%$ over a 10-12-year payback period. All power produced from this project will be purchased by Zheyang City at $0.7 \mathrm{RMB} / \mathrm{kWh}(\$ 0.085 / \mathrm{kWh}$ U.S.). The project was scheduled for completion by June 1999.

Currently, there are no partners for development of this project; however, the company welcomes foreign investment and would be willing to enter into a joint venture agreement. Because Germany is providing soft loans to the Chinese, it is unlikely the Chinese will buy anything other than German-made turbines for this project.

\section{Six Additional Wind Projects}

There are six other projects that the company wishes to develop. These projects stem from a policy that forbids any new coal power plants from being developed near the Pearl River Delta. The government's plan is to use nuclear, natural gas, and wind power plants in this area. However, the amount of foreign interest is critical in determining whether or not these next six projects will be built. These six projects, each $15 \mathrm{MW}$ in capacity, will be located in Sanwei (two projects), Jianzhang (two projects), and Yanjiang (two projects). It is unclear when these projects will be developed, but it appears that they will not begin until after 2000 .

For all of these projects, the provincial utility is willing to provide warranties to back the commercial loans. Although the local utility is the main investor, typically, it allows the other entities to develop the project. The utility boasts strong financial status with fixed assets valued at over 30 billion RMB (\$3.6 billion U.S.).

Guangzhou Institute of Energy Conservation

Main Contact: $\quad$ Chen Guoju, Director

Address: $\quad 81$ Central Martyrs Road, 510070, Guangzhou, P.R. China

Telephone: $\quad$ 8620/87767362

Fax: $\quad 8620 / 87779767$

The Guangzhou Institute of Energy Conservation is a research organization and manufacturer of products for all types of energy resources. The Institute was formed in 1978 under the Chinese Academy of Sciences. It specializes in research and technology in the following fields: 
- Renewable energy : solar, biomass, ocean, and geothermal energy.

- Efficient utilization of industrial thermal energy: waste heat utilization, waste heat refrigeration, heat pumps, energy-saving materials, energy storage, and clean burning.

- Energy conversion technology.

\section{Company Objective}

The main objective of the Institute is to exploit new energy sources and clean combustion to heighten energy utilization and energy efficiency. This will, in turn, abate environmental pollution produced from fossil fuel and industrial waste.

\section{Company Products}

The Institute engages in new-product development and boasts a large product line. These products range from solar hot-water heaters to on-shore wave power stations. A complete list of products is in Appendix A.

\section{Solar Products}

Many of their solar products are designed for industrial and urban use. As part of the Ninth Five-Year Plan, the Institute was involved in several large projects that included solar air conditioning and water heating. One system, installed on a 24-story building, used a total of $500 \mathrm{~m}^{2}$ of solar collectors. This system heated water for the entire building while providing air conditioning for one of the floors. Their collectors are designed for $80^{\circ} \mathrm{C}$ temperatures, but function at $60^{\circ} \mathrm{C}$ temperatures.

\section{Solar Ice Making}

The Guangzhou Institute is in the process of developing solar ice makers. They have developed a prototype that can make $5 \mathrm{~kg}$ of ice per $1 \mathrm{~m}^{2}$ of solar collectors. They anticipate that this product will come into production soon.

\section{Solar Hot-Water Heaters}

The Institute sells approximately $10,000 \mathrm{~m}^{2}$ of solar hot-water collectors per year. Their main market is in Guangdong, but company officials feel that there are much better markets in other areas of China. The average price for their solar hot-water heaters is relatively high compared to that of other manufacturers in China (2,500 RMB $/ \mathrm{m}^{2}$ or $\$ 300 / \mathrm{m}^{2}$ U.S.).

\section{Biomass Products}

The biomass unit of the Institute started out in rural energy, but shifted their focus to urban uses as Guangdong became more urbanized and developed. Most of their biomass products have yet to be commercialized. However, they have installed several systems which are in operation throughout the country. Principally, they focus on wood waste, agricultural waste such as fuel from rice husks, and urban waste.

\section{Rice-Husk/Gas Engine Gasifier}

This is one of the principal projects associated with China's Ninth Five-Year Plan. The system is a $1,000-\mathrm{kW}$ generator that runs on the gas produced from rice husks. The consumption rate for fuel is 35 tons of rice husks per $1,000 \mathrm{~kW}$ of output. The Institute has sold 10-15 sets of similar gasifiers with capacities of $200 \mathrm{~kW}$ each. These systems were sold to various rice farms in Fujian and Southeast Asia. Currently, they control only $1 \%$ of the entire market for these kinds of gasifiers. 


\section{Biomass Circulating Fluidized-Bed Gasifier}

This project primarily uses tree bark and sawdust for its main fuel sources. Its principal target market is the industrial user, including timber mills and factories that produce small-particle wood wastes. So far, 10 systems have been installed in Guanxi, Hainan, Fujian, and Guangdong. Their goal is to launch a joint venture with a foreign entity and bring this product to commercialization.

Their principal problem, however, has been the elimination of pollution from the gasification process. Institute officials have traveled to Europe to research ways of extracting tar from the gas and using the gas for electrification. Apparently, the cost of extracting the pollutants from the gas makes this process uneconomical for commercialization. However, according to the Institute, they are close to perfecting the process. A more detailed explanation of this project is described in Appendix E.

\section{Urban Waste Project}

Another of the Institute's projects is the utilization of urban waste to generate electricity for heat. They are using small towns for this pilot project and hope to expand it to larger urban areas as the process becomes more economical. One of the locations is in Donghuan County, where 15 tons of waste are treated per day. Preliminary results indicate that in order to make this economical for electricity production, at least 100 tons of waste needs to be treated.

\section{Projects Open for Foreign Investment and Partnership}

The Institute is always open to partnerships involving their various product lines. They are looking for partners to assist them with their research, investment, and in the upgrading of their product lines. In addition, the Institute plans to build a wind farm near Shenzen if they can get enough investment.

\section{Accumulating Chinese Renewable Energy Commercialization Capability Project}

The Institute wants to develop a bagasse/wind project in sugar mills in Guangdong using a $\$ 8.27$ million (U.S.) Global Environment Facility (GEF) grant. The project calls for a series of pilot projects and experiments with bagasse/small wind hybrid systems. The desired outcome would be to develop a system that they could market throughout China.

\section{Guangdong Feng Shou Sugar Development Company \\ Main Contact: $\quad$ Huang Guo Tao, President \\ Telephone: $\quad$ (86759) 8944037 \\ Fax: $\quad$ (86759) 8944149}

Feng Shou Sugar Development Company is a comprehensive company primarily involved with sugar, canned pineapple, and wood production. The company has a built-in cycle of production that uses the bagasse from the sugarcane to produce energy. By-products of that process are used to produce particleboard, fertilizer, and alcohol. The fertilizer is used to grow more sugarcane and pineapple. The waste produced by processing the pineapple is reprocessed into animal feed for a pig farm, which the company also maintains.

The company is state-owned; its principal shareholders are from both the central and local branches of the Agriculture Cultivation Bureau under the Ministry of Agriculture. Last year's total revenues and profits were comparatively low at 450 million RMB (\$54.7 million U.S.) and 46 million RMB (\$5.6 million U.S.), respectively, because of a glut in the international sugar market. Their liability-tofixed-assets ratio is $46 \%$. 


\section{Company Objectives}

The main objective of Feng Shou is to increase the scale of sugar production (their main product), to 1 million tons per year by 2000 , while simultaneously improving the local living standards and the ecology. In order to do this they must upgrade their generators from 125 gas tons/hour to at least 150 gas tons/hour. In addition, Feng Shou hopes to raise the production of fertilizer from 20 tons/year to 50 tons/year.

Feng Shou welcomes all foreign investment in the hope that foreign investors will provide capital and updated technology to improve production capabilities.

\section{Sugar Production}

Currently, the company's processing capability is insufficient to meet their goals. Last year, the company was able to process 800,000 tons of sugarcane. However, they will need to upgrade their generators in order to process sugar more efficiently. Currently, the company has four 20-gas-tons/hour generators and one 65-gas-tons/hour generator. Company officials plan to replace three of the four smaller machines with one large machine. Although Feng Shou's operation is designed to produce 145 gas tons/hour of steam for sugar processing, it is only capable of producing 125 gas tons/hour of steam due to inefficiencies. With the upgrade, it will be able to produce 150 gas tons/hour, thereby increasing both sugar and energy production.

\section{Energy Production}

The bagasse from the sugarcane is used as fuel for the gasifiers. Most of the energy from the gasifiers is used to produce sugar (110 gas tons/hour). The remaining energy is sold to the utility at $0.4 \mathrm{RMB} / \mathrm{kWh}$ (\$0.05/kWh U.S.). Feng Shou has entered into a 10-year agreement with the local utility for the purchase of this energy. It costs the company only $0.2 \mathrm{RMB} / \mathrm{kWh}(\$ 0.03 / \mathrm{kWh} \mathrm{U} . \mathrm{S}$.); therefore, if capacity is increased, an increase in both sugar revenues and energy revenues is likely.

Current consumption of electricity for the sugar mill is $7,000 \mathrm{~kW} /$ hour. With their current capacity, they are able to produce $10,500 \mathrm{~kW} /$ hour. Company officials expect that after the upgrades, they will be able to produce $15,000 \mathrm{~kW} /$ hour while consuming only $9,500 \mathrm{~kW} /$ hour.

In addition to bagasse energy production, the company maintains two small hydro plants, each with a capacity of 1.3 MW. The power not used by the company is sold to the utility for $0.3 \mathrm{RMB} / \mathrm{kWh}$ $(\$ 0.04 / \mathrm{kWh}$ U.S.). The company pays about $1 \mathrm{RMB} / \mathrm{kWh}(\$ 0.125 / \mathrm{kWh}$ U.S.) and feels that the price they receive from the utility is too low. Company officials cite a 1996 SETC directive stating that utilities should pay more for energy produced by renewable sources.

\section{Pineapple Production}

Waste from processing the pineapple is not used for energy production. Feng Shou exports $100 \%$ of its canned pineapple, primarily to Europe, the United States, and Canada. Feng Shou currently exports 85\% of all the pineapple produced in China. This venture has become extremely profitable for Feng Shou, netting 6 million RMB (\$723,000 U.S.) last year.

\section{Biogas Energy Production from Wastewater}

Feng Shou also produces alcohol as a by-product of their entire processing procedure. This part of their business is relatively small. However, the waste created from alcohol production is used for producing the fertilizer that is so critical to the company. This process also creates a great deal of wastewater, 
which has not been used for any purpose. Company official are looking for partners to bring technology that would convert the wastewater to biogas, which, in turn, would be used for energy production.

\section{Suixi Beipo Sugar Mill}

Main Contact: $\quad$ Liu Chang Quan, President

Telephone: $\quad$ (86759) 7171403

Fax: $\quad$ (86759) 7171348

Suixi Beipo is another comprehensive sugar mill that engages in alcohol, particleboard, and energy production. However, company officials have said that they have no future plans to expand their energy production. They feel that expanding the particleboard component of their business is more profitable because they hold the patent on a super-strength version of this type of board.

\section{Energy Production}

Currently, the mill produces 70,000 tons of bagasse per year. Three-quarters of the bagasse is used to produce power, and the rest is used to produce particleboard. The total production for power is based on a 90-day period because that is the total time that bagasse can be produced. During this period, $8,000 \mathrm{~kW} /$ day are produced. The company sells approximately $1,500 \mathrm{~kW} /$ day to the utility at $0.44 \mathrm{RMB} / \mathrm{kWh}(\$ 0.06 / \mathrm{kWh}$ U.S.).

In addition to electricity production, the company uses wastewater from the alcohol production to produce biogas for fueling the company boilers and for household heat, which is used for workers living on the premises.

\section{Biogas Commercialization}

Suixi Beipo has already invested 40 million RMB (\$4.8 million U.S.) in developing its business. This investment includes a pipeline that extends throughout the company grounds. Company officials would like help commercializing this gas, but need to improve the purity of the gas before it can be fully commercialized. The current heat value $/ \mathrm{m}^{3}$ is 6,000 calories with $55 \%$ methane content. Already, the company can produce $30,000 \mathrm{~m}^{3}$ of gas/day, which is enough to supply 20,000 households. 


\section{Jiangxi Province}

\section{General Overview}

Jiangxi Province is a relatively poor, agrarian-based province with very little heavy industry. The small amount of heavy industry is a direct reflection of the low level of energy consumption throughout the province. Local government officials place Jiangxi Province's power consumption at about $51 \%$ of the national average.

The total installed capacity in Jiangxi is $5.4 \mathrm{GW}$, of which $75 \%(4,050 \mathrm{MW})$ is produced by coal-fired power plants and the remaining $25 \%(1,350 \mathrm{MW})$ from hydropower plants. Currently, power shortages only occur during the peak hours (between 7:00 and 9:00 p.m.). This situation is not considered to be too serious, and the power bureau is reluctant to invest in new power production. However, power bureau officials have indicated that as the demand increases, plans for new power development will grow as well. At the moment, government officials expect the local economy to grow between $5 \%$ and $6 \%$ per year; thus, local power consumption should increase as well.

In the short term, the main focus of the local power bureau will be to upgrade the current equipment and controllers. In addition, there are plans to upgrade the transmission system within Jiangxi. In June 1998, local Planning Commission officials traveled to Beijing to discuss upgrading the transmission system. The results of those meetings have not yet become available.

Although current short-term plans do not include too much new power development, local government officials are aware that there are abundant wind and solar power that can be exploited. They have included renewable energy development in a long-term plan (for 2010-2015) calling for the exploitation of local wind resources for grid-connected power production. Although local government officials have no specific plans for the amount of development that will occur, central government officials have specified $50 \mathrm{MW}$ of grid-connected wind power by 2000.

\section{Major Governmental Institutions Involved with Renewable Energy}

\section{Local Economic and Trade Commission (ETC)}

Main Contact: $\quad$ Yin Mei Gen, Deputy Director, Rural Energy Department

Main Contact: $\quad$ Zhang Zhu Chun, Deputy Director, Energy Department

Address:

5th Floor, Government Building, 69 Beijing West Road, 330046 Nanchang, Jiangxi, P.R. China

Telephone: $\quad$ (86791) 6262339 or 6222750

Fax: $\quad$ (86791) 6229074

This agency is in charge of energy and industry affairs. They are not involved with the actual development of renewable energy projects, but do make arrangements for all investment activities within the province. 


\section{Jiangxi Jiu Jiang City Electric Power Bureau}

Main Contact:

Zhao Bao Heng, Deputy Director

Telephone:

(86792) 846490

This bureau is responsible for Xingzi County, a region where there are excellent wind resources and where future sites for wind farms are located.

\section{Jiangxi Provincial Electric Power Corporation}

Main Contact: $\quad$ Xu Shaoan, Engineer

Address:

No. 13 Yongwaizheng Street, 330006 Nanchang, Jiangxi, P.R. China

Telephone: (86791) 6225036

Alternate Contact: $\quad$ Chen Ruiyuan, Chief Director, Rural Electrification Division

Telephone:

Fax:

This company is in charge of negotiating and/or approving all power purchase agreements within the province. Local power bureaus under this company can negotiate PPAs at a local level; however, all PPAs must go through this organization.

\section{Jiangxi Provincial Planning Commission}

Main Contacts: $\quad$ Ye Boqing, Wang Feng

Address:

Telephone: No. 69 Beijing Xi Road, 330046 Nanchang, Jiangxi, P.R. China

Fax: (86791) 6200228 (86791) 6200228

\section{Rural Energy Management Group of Xingzi County \\ Main Contact: $\quad$ Liu Ci Fang, Group Leader \\ Telephone: $\quad$ (86792) 2665401 \\ Fax: $\quad$ (86792) 2666518}

This group has 16 renewable energy offices representing each township in the county. Xingzi County is the primary area in Jiangxi where renewable energy technologies are used. It includes the Poyang Lake and Duchang areas where most, if not all, large-scale wind farm activities will take place.

\section{Legal Environment}

The Jiangxi provincial government is caught in a dilemma with regard to providing incentives other than those provided by the central government. The problem is that the province has very rich wind resources, but very little money and energy demand to make it worthwhile to invest in new energy development. The government expects future economic growth in Jiangxi. However, no major industries, with the exception of a few auto manufacturers, have set up operations in the province. This would indicate that no surge in demand would occur in the near term. Therefore, there is very little incentive for the local government to implement policies that would encourage new renewable energy development.

In addition, the local government seems completely dependent on the central government for making policies that would affect the economy. In all situations, when local government officials were asked 
about implementing policies specific to Jiangxi Province, they referred the interviewer to the State Development Planning Commission.

\section{Competitive Environment}

\section{Overview of Renewable Energy Technologies}

\section{Bioenergy and Biomass Utilization}

In Jiangxi, biomass is usually burned directly for heating and cooking in the rural areas. However, there are projects that have converted waste into biogas for not only heating and cooking, but also for lighting as well. Two of the main areas for biogas utilization, amongst other renewables, are in Xingzi County.

\section{Xingzi County}

The Xingzi County government has put great emphasis on renewable energy development. Because tourism is the county's main industry, a high value has been placed on maintaining the ecological beauty of the area. Another reason for renewable energy development is the direct economic benefit it has received. Government officials estimate that more than 10 million RMB (\$1.2 million U.S.) is saved each year through the use of renewable energy.

The county, nevertheless, has relatively limited biomass resources due to a National Law that limits the amount of wood which can be cut in the area. Because Xingzi County contains the Lushan Resort area, considered to be a national treasure, logging is strictly prohibited. Therefore, biogas is heavily used by the rural population. In fact, household biogas - primarily for cooking, heating, and lighting - has penetrated more than $50 \%$ of the 40,000 households in the county. The biogas is produced using pig waste in combination with either vegetable, fish, or fruit waste.

Xiu Feng Village

Xiu Feng uses a comprehensive biogas system common in most villages throughout the county. There are 40 households in this village, each with a digester connected to a pipeline through which gas is distributed. Each digester is about $6 \mathrm{~m}^{3}$ in size and is capable of producing about $1 \mathrm{~m}^{3}$ of gas (enough for 4-5 people).

\section{Geothermal Utilization}

There are some geothermal resources in Jiangxi Province. However, average temperatures of this resource are about $78^{\circ} \mathrm{C}$. Geothermal resources are not used extensively for power generation or heating. They are used primarily for tourism.

\section{Hydropower Utilization}

As indicated above, hydropower accounts for about $25 \%$ of the province's entire energy portfolio. There are about $30 \mathrm{~kW}$ of installed microhydro capacity in the rural, mountainous areas. These systems range in capacity between $300 \mathrm{~W}$ and $3 \mathrm{~kW}$. However, because the population in these mountainous regions is extremely sparse, the market for such systems is relatively small. Nevertheless, government officials see microhydro systems as the most cost-effective renewable energy resource for many of these remote areas, and there are plans to add additional hydropower capacity. 


\section{Solar Power Utilization}

Because biogas and microhydro sufficiently meet the current energy demands of the rural population, local government officials have not put too much emphasis on photovoltaics for energy production. However, one of the main goals of the Jiangxi government is to enhance solar thermal technology for water heating.

The summer and fall seasons generally provide the best solar resource. The industry is relatively new in Jiangxi, with fewer than 10 enterprises involved in solar water heater manufacturing. None of these enterprises have developed their own technology; rather, they imported the technology from Qinghai University.

\section{Pilot Project}

The local ETC implemented a pilot project in which about 100 officials from the agency had solar water heaters installed in their homes. The project was successful. However, the price for the systems was considered too high. These solar water heaters cost, on average, about 1,500-2,000 RMB (\$182-\$243 U.S.) per 80-liter system. Officials estimate that if the price can be reduced to about 1,000 RMB (\$121 U.S.) per system, the market will be very large.

\section{Wind Energy Utilization}

Jiangxi Province has some of the most abundant wind resources in the region. In some areas, there are more than 200 days with class 3 winds $(4.5 \mathrm{~m} / \mathrm{s}$ at a height of $10 \mathrm{~m})$. Unfortunately, the province is comparatively backward relative to its more developed neighbors, Guangdong and Fujian. Therefore, its infrastructure is less developed and its power demand is much less. The SDPC recently held two meetings to upgrade the transmission lines; however, no details are known and no time line has been set for this upgrade.

\section{Wind Farm Sites}

Two wind farms (Poyang and Duchang) are being planned for Jiangxi. Both sites are located near Poyang Lake in Xingzi County. Poyang is in the feasibility stage whereas Duchang is in the prefeasibility stage. The size of these wind farms will be determined by the amount of funding that they are able to obtain. However, it is estimated that the total wind potential of the Poyang and Duchang areas could be as much as 3,000 MW. Usually, the peak winds occur during low power consumption times (between 10:00 p.m. and 7:00 a.m.).

The Chinese are primarily looking for soft loans from foreign governments; however, they have not ruled out entering into a BOT scheme. It may be some time before any real investment will be made, because transmission upgrades will be needed to carry the loads of large wind farms. In addition, the lack of current power demand, combined with a low power price, will make it difficult to enter into any commercial agreement.

\section{Near-Term Development}

Local government officials do have near-term plans to install two $300-\mathrm{kW}$ turbines at Poyang and Duchang in order to test their performance and their reaction to the complex winds in the area. 


\section{Economic Environment}

Because of Jiangxi's economic situation, the population has little extra disposable income. Unemployment is much higher than in its neighboring provinces because there is very little industry in Jiangxi. The following table outlines the economic situation in Jiangxi.

Table 5. Average Income and Cost of Living Per Capita in Jiangxi in 1997

\begin{tabular}{|l|c|c|c|}
\hline \multicolumn{1}{|c|}{ Location } & $\begin{array}{c}\text { Average Net Income } \\
\text { (U.S.\$/year) }\end{array}$ & $\begin{array}{c}\text { Average Cost of } \\
\text { Living } \\
\text { (U.S. \$/year) }\end{array}$ & $\begin{array}{c}\text { Registered } \\
\text { Unemployment }\end{array}$ \\
\hline \hline Town and City & 460 & 358 & $4,290,000$ (total) \\
\hline Rural Areas & N/A & N/A & \\
\hline
\end{tabular}

Source: Center for Renewable Energy Development

\section{Cost of Electricity and Energy Consumption}

The price of energy is determined much like it is in other provinces. First, the local government submits a recommended price to both the SPC and the Pricing Bureau of the SDPC. The SDPC and SPC must approve that price before it can be implemented. Usually, the price is determined based on the investment source (foreign or Chinese, BOT or straight loan), the amount of energy expected from the power plant, and reasonable profit.

Typically, a higher price is allowed when there is a BOT scheme, or when a foreign partner is involved who brings in foreign investment. The amount of power expected from the power plant is important because the Chinese typically like to spread the cost of energy across the entire grid. Therefore, the government would be less likely to approve a several-hundred-megawatt wind farm over a wind farm of less than $100 \mathrm{MW}$. This way, the higher cost of energy can be absorbed by the rest of the grid without increasing the overall average price. Finally, the price will include a reasonable profit. Usually, the Chinese will try to keep a developer within the $12 \%-15 \%$ profit range. However, as is the case in all of China, everything is negotiable.

\section{Electricity Price}

Average electricity prices in Jiangxi, unlike those in other poorer provinces, are not very low. In some cases, they are very high. In extreme cases, some remotely located consumers pay more than $1.3 \mathrm{RMB} / \mathrm{kWh}(\$ 0.16 \mathrm{U} . \mathrm{S} . / \mathrm{kWh})$. High prices for grid-connected energy can be found in Xingzi County (\$0.10-\$0.11 U.S./kWh), which makes wind development in that region more desirable than in other regions within that province. However, the high price for the grid-connected power is attributed to the large amount of distribution loss during transmission; it is not, however, regarded as an incentive to promote wind energy development.

\section{Energy Consumption}

The industrial sector in Jiangxi Province consumes far less energy than industry in other, more developed provinces. However, within the province, the industrial sector consumes $75 \%$ of all the province's 
energy (see Table 6). The province as a whole consumes relatively little power (only 21.32 million tce per year).

Table 6. Breakdown of Power Sectors in Jiangxi

\begin{tabular}{|l|c|c|}
\hline \multicolumn{1}{|c|}{ Sector } & $\begin{array}{c}\text { Power Generation/Year } \\
\text { (million tce) }\end{array}$ & $\begin{array}{c}\text { Average Power Price } \\
\text { (U.S. \$ /kWh) }\end{array}$ \\
\hline \hline Agricultural & 1.21 & 0.05 \\
\hline Industrial & 15.89 & 0.05 \\
\hline Institutional & 0.44 & 0.05 \\
\hline Residential & 2.83 & 0.05 \\
\hline
\end{tabular}

Source: Jiujiang City Electric Power Bureau

\section{Geographic Environment}

The topography in Jiangxi Province is rather diverse. The eastern part of the province consists of lowlying agricultural land. Oftentimes, this land is subject to flooding during the rainy season (JuneAugust). The central part of Jiangxi consists of mountains and valleys; it is in this region where Poyang Lake is located. The rugged mountains near the eastern shore and the rolling hills along the western shore create a wind corridor down, and across, the lake.

\section{Technological Environment}

Development in Jiangxi has been rather slow. However, the central government has discussed upgrades of the transmission system, and new transmission lines are expected within the next five years.

Jiangxi's network of roads is adequate in the principal cities and in the main tourist areas. However, travel to remote areas is difficult at best. During the rainy season, many roads are impassable. In times of major flooding, the entire resources for maintaining the infrastructure come to a complete halt. All efforts and resources are usually directed towards maintaining basic needs such as electricity and water.

Jiangxi's telecommunication system is fairly modern. International communication should not be a major concern for any entity wishing to enter the market. In addition, there is plenty of access to the most modern computing hardware and software. Manufacturing techniques and equipment, however, are a bit backward. Most foreign firms will have to provide the assembly lines necessary to manufacture the most advanced renewable energy products.

\section{Sociocultural Environment}

Social attitudes on renewable energy vary throughout Jiangxi. However, economic concerns are the major basis for these attitudes. For example, the attitudes of the residents of Xingzi County are very favorable. The local economy, however, depends on the pristine beauty of the area, and local and national laws restrict the amount of pollution that goes into the environment.

The provincial power bureau sees renewable energy as beneficial. However, power bureau officials only seem willing to purchase wind power, for example, if the price is below $\$ 0.05 / \mathrm{kWh}$ U.S. There seems to 
be a conflict between developers, who want a higher price for the power they produce, and the grid. For example, a sugar mill can generate its own power and consume the power it produces. The power company does not look favorably on that situation because less energy is consumed from the grid, leading to less profits for the power company. This situation may have an adverse effect on future policies that encourage the development of renewable energy because the power bureau contributes to the policy development of the province.

\section{Profile of Renewable Energy Company}

There are very few enterprises involved with renewable energy development and manufacturing. The entire development of Xingzi County, where the majority of renewable energy activity is located, is controlled by the Jiujiang Electric Power Bureau.

\section{Jiujiang City Electric Power Bureau}

Main Contact: $\quad$ Zhao Bao Heng, Deputy Director

Telephone: $\quad$ (86792) 8464907

The Jiujiang City Electric Power Bureau is the main entity involved in wind power development. This company is the sole developer of the two aforementioned sites in Xingzi County.

Near-Term Prospects for New Power Investment

Power bureau officials believe that as the Three Gorges Hydropower plant comes on-line, the power supply for the region will be sufficient to meet near-term demand. Currently, the province imports some of its energy from the Gezhouba Hydropower plant in Hubei Province. This power is bought for less money than power generated by local coal-fired power plants. The cost for imported hydropower is less than $0.3 \mathrm{RMB} / \mathrm{kWh}(\$ 0.04 / \mathrm{kWh}$ U.S.), whereas local, coal-fired power costs more than $0.3 \mathrm{RMB} / \mathrm{kWh}$. This situation, combined with the slow growth in energy demand, leads to very little incentive to develop new power plants in the province.

\section{Jingan Hydropower Plant}

Jiujiang Power does have plans, however, to develop a 2.4-GW hydropower station. The reason for these plans is that power company officials believe they can only import so much power from outside sources before it becomes too expensive. This power plant will be built in two stages, with each stage being $1.2 \mathrm{GW}$. At the moment, this project is in the feasibility stage and must be approved by the SDPC. Power bureau officials did not seem overly enthusiastic about having any foreign involvement with this project. They indicated that they would prefer to use domestically manufactured equipment and said that it was up to the SDPC to decide whether or not foreign involvement would be allowed. Regardless of this lack of enthusiasm towards foreign partnership and investment, it is inevitable that the utility will seek assistance abroad in developing the project. 


\section{Jilin Province}

\section{General Overview}

Jilin Province is sparsely populated, with a total of 2 million people living within its boundaries. The population density averages about 136 people $/ \mathrm{km}^{2}$. Jilin is one of the few eastern coastal provinces that is still in the midst of making the transition from an agrarian to an industrial society. Currently, there is a large agricultural base; the major crops are rice and corn. The province is also well known for its automobile and chemical manufacturers.

Jilin has abundant oil, biomass, solar, hydro, and wind resources. Current oil production is about 4.1 million tons per year, most of which is exported either to other provinces within China or to other countries in Asia. Despite these rich resources, Jilin still imports almost half of the 4.8 million tons/year of coal for energy production. Jilin has very scarce coal reserves and the reserves that it does have are of very poor quality. Current installed capacity is $6,523 \mathrm{MW}$. Of that capacity, hydro is about 3,100 MW, or $48 \%$, of the installed capacity. The remaining capacity comes from coal-fired power plants. $27.3 \%$ of the entire installed capacity is connected to the northeast grid, which includes Heilongjiang, Jilin, Hebei, and part of Inner Mongolia.

The Jilin government does have plans to develop some of its renewable energy resources on a large scale. Exploiting the province's wind and hydro resources has been the main focus of this plan. Some research organizations are experimenting with centralized biogas operations, primarily for heating, cooking, and lighting, and it is hoped that these programs will begin to be commercialized and implemented on a large scale as well. Because the majority of Jilin's population already has access to electricity, the local government has no plans for implementing rural electrification programs and does not see a current need for stand-alone or village-scale systems.

\section{Major Governmental Institutions Involved with Renewable Energy}

The responsibilities of Jilin's government institutions are the same as those mentioned in previous chapters. The following is a list of the main agencies involved in renewable energy:

Jilin Province Economic and Trade Commission

Main Contact: $\quad$ Lu Lian Da, Ph.D., General Manager, Planning Department

Address:

Telephone: No. 11 Xunfa Road, 130054 Changchun, Jilin, P.R. China

Fax: (86431) 8904698

(86431) 8917697

\section{Jilin Provincial Electric Power Bureau}

Main Contact:

Address:

Telephone:

Fax:

Alternate Contact:

Telephone:

Fax:
Wang Bing Hua, President

139 Renmin Street, 130021 Changchun, Jilin, P.R. China

(86431) 5642793 or $5642702-3701$

(86431) 5642829

Li Ben Han, General Manager

(86431) 5643467 or 5613398

(86431) 5643467 
Jilin Province Energy Resource Institute

Main Contact:

Gu Hui Qing, Director/Senior Engineer

Address:

No. 27 Nanhu Road, 130012 Changchun, Jilin, P.R. China

Telephone:

(86431) 5953461-7 (ext. 209)

Fax:

(86431) 5969007

Alternate Contact: Qiang Jian, Vice Director

Telephone:

(86431) 5969004

Fax:

(86431) 5969007

Jilin Province Planning Commission

Main Contact:

Zhang Yan

Address:

No. 11 Xinfa Road, Changchun, Jilin, P.R.China

Telephone:

(86431) 8904578

\section{Legal Environment}

The Jilin government is determined to develop its large-scale renewable energy resources. It has taken several steps to bolster national-level incentives and enforce those regulations that punish polluters. The following are some of the laws and incentives that promote clean, sustainable development:

\section{Strict Enforcement of National Environmental Protection Law}

The local government strictly enforces national regulations and takes swift action against those enterprises that pollute the environment. Government officials are taking the following steps:

1. A fine is levied on the polluting enterprise.

2. A notification, additional fines, and a deadline for compliance are given.

3. If the enterprise continues polluting, it is closed indefinitely.

\section{Tax Reductions}

Enterprises involved in renewable energy can enjoy a reduction in VAT and income taxes.

\section{Priority Loans from Banks}

"Priority" in this case does not mean low interest. It only means that the application for the loan will be given priority over those of other enterprises. However, getting this type of priority can save an organization a good amount of time and, therefore, allow an enterprise to begin operations in a reasonably timely manner.

\section{Priority Land Use and Reduction in Land Use Fee}

If more than one enterprise is interested in the same plot of land, the government will give priority to an enterprise involved with renewable energy. In addition, the fee to use this land will be reduced. 


\section{Marketing Assistance}

The government will assign a special agency to assist the enterprise with selling its products. The government will recommend these products for use in other government-sponsored projects. This policy is extended to Chinese, foreign, and joint-venture enterprises that are involved in the comprehensive utilization of waste or natural resources.

\section{Special Provincial Policy on Wind Energy}

Because wind energy is considered to have the most promise for large-scale development in Jilin, the government has developed the following special policies for the industry:

1. All wind power plants can be directly connected to the grid and the power must be purchased by the utility.

2. All electricity produced by a wind farm will receive at least $1 \mathrm{RMB} / \mathrm{kWh}(\$ 0.125 / \mathrm{kWh}$ U.S.) during the payback period of the loan for the initial capital investment.

3. All wind energy enterprises will receive a tax holiday for the first three years of operation. The enterprise will have to pay only $50 \%$ of the required income taxes during the following two years.

4. A reduction in land use fees is extended to wind farms as it is to other renewable energy enterprises. There may be more of a reduction for wind farms, however, than for other renewable energy enterprises; however, the amount of reduction is not known.

\section{Competitive Environment}

\section{Overview of Renewable Energy Technologies}

\section{Bioenergy and Biomass Utilization}

Jilin Province's agricultural industry consists mainly of corn and rice production. The province has 6 of the 10 largest corn- and rice-producing counties in the entire country. A by-product of this industry is the relatively abundant resource of biomass material, netting about 35 million tons/year of straw from the agricultural waste. Of that 35 million tons, 28 million tons/year of straw comes from corn crops. Much of this straw is unused and either rots or is burned for disposal. Wasting this resource has raised the attention of the local government and has caused it to seek ways of utilizing the resource in productive ways.

Because the majority of the biomass material comes from corn husks, the focus of most of the research is on this source of fuel. (Please see description [pg. 39] of Jilin Province Energy Resources Institute (JERI) for details of biomass projects.) Current research is focused on creating biogas from this material because farmers and other rural inhabitants burn the straw directly for cooking and heating, which is extremely inefficient and polluting. 


\section{Hydro Utilization}

All areas of Jilin are connected to the grid. Therefore, the market for micro-hydro systems is nonexistent. All plans for hydropower development are for large-scale power plants. Jilin has about 5,000 MW of available hydro resources, of which 3,100 MW has already been exploited. Currently, $700 \mathrm{MW}$ of hydro capacity is being developed.

\section{Goal of Hydropower Development}

The Jilin government has set a goal of $85 \%$ of all provincial hydro resources to be developed by the end of 2010. However, achieving this goal depends on the availability of financial resources and the longterm goal for the country's development. Meanwhile, some projects have been approved, while others are waiting for financing to come through before actual implementation can begin. (Please see Jilin Wind Power Stockholding Co., Ltd. [p. 40], for description of hydro projects.)

\section{Solar Power Utilization}

Very little solar technology is used in the province. Because all areas within Jilin are grid-connected, PV technology has very limited uses beyond communication and other non-household power systems markets. Solar thermal hot-water heaters are becoming more popular in Jilin; however, better markets exist elsewhere throughout China.

\section{Wind Energy Utilization}

Jilin has excellent wind resources and plans are under way to exploit them. The local government feels that $300 \mathrm{MW}$ can be developed within the current capability of the existing grid. The estimated amount of energy that can be produced by this resource is $6,920 \times 10^{9} \mathrm{kWh}$.

The principal wind resources in this province are located along the western border with Inner Mongolia and along the eastern coastline. The first area of development will be on the Jilin-Inner Mongolian border in the Tongfa region. Total capacity to be developed in Tongfa is $100 \mathrm{MW}$. (Please see Jilin Wind Power Stockholding Co., Ltd. [p. 40], for more information on these wind projects.)

\section{Utilities}

All electricity produced in Jilin must be sold to Jilin Provincial Power Bureau. However, there are about 40 different utilities in Jilin. Each county has its own utility and is part of the county government, and is not under the provincial power bureau. The provincial power bureau redistributes the energy back to the counties and the county utility distributes the energy to the local residents.

\section{Economic Environment}

The economy in Jilin has been expanding rapidly over the past several years, growing 9.5\% since 1996 . Jilin's 1997 gross domestic product (GDP) was 145 billion RMB ( $\$ 17.62$ billion U.S.). The major heavy industries have typically been automobile and chemical manufacturing. However, the electronics and processed-foods industries have been growing steadily. This trend seems to be continuing in 1998 despite the economic crisis in Southeast Asia. Jilin's GDP grew more than 8\% during the first six months of 1998. Average per capita income is outlined in the table below: 
Table 7. Average Income and Cost of Living Per Capita in Jilin

\begin{tabular}{|l|c|c|c|}
\hline \multicolumn{1}{|c|}{ Location } & $\begin{array}{c}\text { Average Net Income } \\
\text { (U.S.\$/year) }\end{array}$ & $\begin{array}{c}\text { Average Cost of Living } \\
\text { (U.S.\$year) }\end{array}$ & Registered Unemployment \\
\hline Urban Areas & 463 & 370 & $6,280,000$ (total) \\
\hline Rural Area & 350 & 300 & - \\
\hline
\end{tabular}

Source: Center for Renewable Energy Development

\section{Price of Electricity}

The price of power is usually given final approval by the Pricing Bureau of the SDPC. However, it is first negotiated with the provincial power bureau. Table 9 provides a breakdown of the average electricity prices paid by the various sectors in Jilin.

\section{Energy Consumption}

The main consumers of energy are the automobile and chemical industries. These two industries, combined with the growing electronics industries, consume almost $76 \%$ of Jilin's total power. The following table outlines the energy consumption and the price each sector pays for its electricity.

Table 8. Breakdown of Individual Power Sectors in Jilin

\begin{tabular}{|l|c|c|}
\hline \multicolumn{1}{|c|}{ Sector } & $\begin{array}{c}\text { Power Consumption/Year } \\
\text { (Million tce) }\end{array}$ & Power Price (US\$/kWh) \\
\hline Agricultural & 0.83 & $0.04-0.05$ \\
\hline Industrial & 23.10 & $0.06-0.10$ \\
\hline Institutional & 3.86 & $0.04-0.05$ \\
\hline Residential & 3.24 & $<0.04$ \\
\hline
\end{tabular}

Source: Jilin Provincial Power Bureau

\section{Price of Wind Power}

In the case of some energy projects, beneficial prices can be negotiated because of the environmental benefits associated with such projects. The higher cost would be spread throughout the entire grid; in Jilin's case, the higher price would be spread throughout the entire northeast grid. This allows several provinces to share the higher price, and enables the provincial power bureau to develop and absorb more wind power into the grid.

\section{Geographic Environment}

Jilin lies in the central part of northeast China and borders three countries. Its eastern border is shared by Russia and the southeastern border is shared by North Korea. These borders are delineated by the Tumen River with Russia and the Yalu River with North Korea. Jilin's total territory is $187,000 \mathrm{~km}^{2}$. 
Forty-eight percent of Jilin consists of grassland, which lies in the western region of the province. The eastern part of the province is mountainous and contains the bulk of Jilin's natural resources such as oil, natural gas, and water. However, there are many oil reserves in the western part of the province as well.

\section{Technological Environment}

Jilin's technological environment is relatively sophisticated compared to that of many rural provinces throughout China. Because it houses many industrial sectors, it has fairly modern manufacturing capabilities. Despite this, the province's industries need updated facilities and production lines to compete effectively in the international market.

Jilin has a good communications infrastructure and all major hotels and research facilities have access to modern computers and the associated software programs.

\section{New Highway to be Built}

Most of the province is accessible by air, train or road. Currently, there is a highway from Changchun to Siping that is part of the Beijing-Harbin Expressway. The Tongfa region in particular is easily accessible by road. However, these roads are currently being upgraded, and an additional superhighway is being constructed that will stretch from Changchun to the Tongfa area. It should then take only three hours to make a trip that now takes five-and-a-half hours.

Jilin has rail access in addition to the highway. In the west, there are four main railways connecting Jilin with the bordering provinces of Heilongjiang and Inner Mongolia. In addition, the province operates its own railway from Tument to Hunchun, which will soon be connected with the Far East Railway of Russia.

\section{Airports}

There are four airports in Jilin. These are located in Changchun, Jilin, Liuhe, and Yanji. Plans to expand facilities at the Changchun airport are under way to meet the demand of new commerce and tourists.

\section{Access to the Sea}

Although Jilin is not a coastal province, there are sea transportation routes accessible to Jilin. These include the Hunchun-Poseit-Vladivostock-Pusan route, the Tumen-Chongjin-western-Japanese-coast route, and the Hunchun-Lajin-Pusan route.

\section{Sociocultural Environment}

The educational system ranges from primary school in the rural areas to postgraduate levels in the urban areas. This educational diversity amongst the rural and urban areas is not necessarily accompanied by a similar diversity in attitudes towards the environment or the use of renewable energy technologies.

Both provincial and county governments acknowledge the fact that all rural areas are already connected to the grid. However, government officials are very concerned about the environment and encourage the use of renewable energy technologies in these rural areas. 


\title{
Attitudes Toward Foreign Involvement in Power Projects
}

Both company and government officials understand that it is legally permissible for foreigners to own and operate power plants. However, many officials do not have a complete understanding of what private ownership entails. Therefore, they look more favorably on joint-venture partnerships than wholly owned foreign enterprises. This attitude could have a definite effect on the negotiation of PPAs and the amount of time it takes to go through the project approval process.

\section{Profiles of Renewable Energy Companies}

\author{
Jilin Province Energy Resources Institute \\ Main Contact: $\quad$ Gu Huiqing, Director \\ Alternate Contact: $\quad$ Qiang Jian, Engineer \\ Address: $\quad$ No. 27 Nanhu Road, 130012 Changchun, Jilin, P.R. China \\ Telephone: $\quad$ (86431) $5953461-7$ (ext, 209) or 5969004 \\ Fax: $\quad$ (86431) 5969007
}

JERI does renewable energy R\&D. The organization also generates income by providing consulting, engineering assistance, and other services. JERI is under the local Economic and Trade Commission and cooperates with local companies in developing new product technology.

Most of JERI's research is focused on converting straw from corn to biogas for energy. The director intends to commercialize this technology, and recently led a staff to Canada and the United States to research state-of-the-art procedures for this type of energy production.

\section{Siping City Centralized Biogas Project}

JERI is currently engaged in a pilot project in Siping City, about $100 \mathrm{~km}$ from Changchun. The biogas that is produced provides enough heating and cooking fuel for a community of about 50 households. In addition, the community has a centralized solar water-heating facility for bathing. Future plans for this project include expanding to several hundred sites of similar size throughout the province.

\section{Four Other Projects with Potential Foreign Involvement}

JERI is planning to implement four additional projects utilizing biogas from local crops. The first project will use straw to produce gas for a centralized gas plant. This gas plant will be much like conventional gas plants in the United States. The initial project would be scaled down to provide cooking and heating fuel for about 500 households. It would then be scaled to a much larger size as the technology becomes more commercial. Farmers, meanwhile, would provide the straw to the gas company in exchange for free gas. The farmers may have to pay a nominal fee for the management of the system, but would essentially get discounted gas service for their crop waste. The excess gas produced from the system would be sold to other end users. The second project involves using the straw for large-scale crop drying; gas would be used to produce heat, which would, in turn, dry rice.

The third research project is for the development of a cogeneration power plant that uses thermal energy from biomass to create steam. Initial capacity of this system would be $200-300 \mathrm{~kW}$. The system would be designed for small villages of approximately 500 households in rural areas. According to JERI representatives, the size of the market throughout China for these types of systems is very large because there are many villages of this size in China. The main objective of this project is to lower the price of rural electricity while simultaneously solving the common problem of disposing of surplus agricultural waste. 
In order to meet this project objective, the economics of the system would have to be analyzed. At the moment, the economics of such a system are poor. However, JERI officials feel that using the straw system combined with modern fuel-cell technology would improve the economics of the entire power plant as well as increase the overall efficiency of the generator. JERI is currently seeking partners to develop this hybrid technology.

The fourth and final project in which JERI is engaged is the production of gas from straw to heat greenhouses. Currently, the Chinese use coal for this purpose. JERI officials believe that developing this opportunity would help in mitigating carbon dioxide $\left(\mathrm{CO}_{2}\right)$ emissions countrywide.

After the demonstration sites are established and initial experimentation is under way, JERI will welcome the participation of foreign institutes and companies. Building of this project commenced in July 1998 and is expected to be completed by the end of the year. If successful, there are plans to expand the plan to other villages in 1999. JERI is seeking partners for investment, technology, and equipment.

\section{Jilin Wind Power Stockholding Company, Ltd.}

Main Contact: $\quad$ Cong Jingquan, Vice-General Manager

Address: No. 20-1 Fengshun Street, 130021 Changchun, Jilin, P.R. China

Telephone: (86431) 5665277

Fax: (86431) 5665444

Jilin Wind Power is the primary developer of both wind energy and hydropower projects. It is a stateowned company with a majority owned by the provincial power bureau. Sixteen other organizations have minority shares in the company. The following projects are currently under way and are open to foreign involvement.

\section{Tongfa Wind Farm}

This wind farm will be built in three stages and is currently in the first stage of development. Construction will begin this year with the installation of 11 MADE $660-\mathrm{kW}$ turbines. The company has signed a 20 -year PPA with the provincial utility to purchase the energy for $1 \mathrm{RMB} / \mathrm{kWh}(\$ 0.125 / \mathrm{kWh}$ U.S.). The Spanish government gave a soft loan that provides $50 \%$ of the financing at $2 \%$ over a 25 -year term. The remaining money will be financed commercially.

The second stage will consist of 30 sets of at least $600-\mathrm{kW}$ turbines; however, a manufacturer has yet to be determined. Jilin Wind Power is seeking soft loans to finance the purchase of those turbines and expects to receive Danish money. Construction for this stage was set to begin in April 1999. Plans were also under way for $43 \mathrm{MW}$ of turbine capacity, to be developed by the end of 2000 . Although the company welcomes foreign investment, it is reluctant to purchase wind turbines without soft loans (see Appendix D).

\section{Additional Plans for Wind Farm Development}

In addition to the abovementioned plans, Jilin Wind Power and the Jilin government plan to install 30 MW each year through 2010 in Tongfa and three other areas, as outlined in the table below. 


\section{Table 9. Areas for Wind Farm Development in Jilin (Yearly Averages)}

\begin{tabular}{|c|c|c|}
\hline Area & Wind Speed at $10 \mathrm{~m}$ Height & Wind Speed at $40 \mathrm{~m}$ Height \\
\hline Tongfa & $5.69 \mathrm{~m} / \mathrm{s}$ & $7.23 \mathrm{~m} / \mathrm{s}$ \\
\hline Panjia & $5.46 \mathrm{~m} / \mathrm{s}$ & $6.95 \mathrm{~m} / \mathrm{s}$ \\
\hline Tuanjie & $5.36 \mathrm{~m} / \mathrm{s}$ & N/A \\
\hline Olanhua & $5.00 \mathrm{~m} / \mathrm{s}$ & $6.36 \mathrm{~m} / \mathrm{s}$ \\
\hline
\end{tabular}

Source: Jilin Wind Power Stockholding Co., Ltd.

\section{Antau County Hydropower Projects}

Two hydropower projects are being planned. The first project has already been approved and will consist of four 200-MW generators. The area of development has a 70-m head and is set to begin operation in 2003. However, the company is seeking funds to begin installation of the power plant.

The second project will be located in the same area. It will be a pumped storage facility and consist of four 125-MW generators. At the moment, the project has not yet been approved, but company officials believe that approval will come quickly. The project will have an $80-100-\mathrm{m}$ head and is expected to be built by 2004. If the project is approved, both this and the abovementioned hydro project will be built simultaneously. Jilin Wind Power welcomes foreign investment and partnership; however, company officials have met with no success after travelling to Canada and the United States. 


\section{Yunnan Province}

\section{General Overview}

Yunnan Province is a region rich not only in natural resources, but in its cultural diversity. The province proudly boasts over 26 minorities living within its borders, each with its own culture and customs. Agriculture (especially tobacco production) is a large part of Yunnan's economy.

The province currently has a relatively low demand for energy. The bulk of its energy (about 70\%) comes from hydropower plants and the rest (about 30\%) from coal-fired plants. Total installed capacity is 6,368 MW. Because the bulk of Yunnan's energy comes from hydropower, the province experiences energy surpluses at times during the rainy season. It is during this season that the provincial power bureau sells approximately 2 billion $\mathrm{kWh}$ of electricity to neighboring provinces. However, during the dry season, the province sometimes has a shortage of electricity and needs to buy power from its neighbors. Last year it had to purchase a half-billion $\mathrm{kWh}$ of electricity from Guizhou at $0.25 \mathrm{RMB} / \mathrm{kWh}$ (\$0.03/kWh U.S.).

The rural areas are very sparsely populated, making it very difficult to justify electrifying the entire population. About 8 million households live in these rural areas, with each household containing approximately 4 people. It is estimated that about 6 million people in Yunnan have no access to electricity. The provincial government had made plans to extend the grid, where possible, or use small micro-hydro systems to meet the demand. During the dry season, photovoltaics may also be used because solar power is abundant. By the end of 2000 , Yunnan plans to electrify $100 \%$ of all its villages or $90 \%$ of all the households in the province. Unfortunately, it will be very difficult to realize this plan because much of the rural area is sparsely populated. The majority of these villages consist of three or four households.

\section{Major Governmental Institutions Involved with Renewable Energy Development}

The major local government agencies that are involved with renewable energy development are:

Geothermal Development Office of Tengchong

Main Contact: $\quad$ Duan Yadong, Director

Telephone: $\quad$ (86875) 5181088

Yunnan Normal University Solar Energy Research Institute

Main Contact: $\quad$ Liu Zuming, Vice Director

Address: $\quad 650092$ Kunming, Yunnan, P.R. China

Telephone: $\quad$ (86871) 5322930 (ext. 6081)

Fax: $\quad$ (86871) 5323804

Yunnan Provincial Agricultural Energy Office

Main Contact: Huang Jingcheng, Director

Address:

Telephone: 52 Dongfeng Xi Lu, 650031 Kunming, Yunnan, P.R. China (86871) 5315381 


\author{
Yunnan Provincial Economic and Trade Commission \\ Main Contact: $\quad$ Li Xianwu, Director \\ Alternate Contact: $\quad$ Zhao Yutang, Deputy Director \\ Address: \\ Dong Feng East Road, 650041 Kunming, Yunnan, P.R. China \\ Telephone: \\ (86871) 3327129 or 3334655 \\ Fax: \\ (86871) 3327129 or 3334653 \\ Yunnan Provincial Electric Power Bureau \\ Main Contact: $\quad$ Xie Kunsheng, Deputy Director/Deputy General Manager \\ Alternate Contacts: $\quad$ Zhen Xinlian, Senior Engineer, Planning Department \\ Zheng Waisheng, Engineer, Planning Department \\ Address: $\quad$ Dongfendong Road No. 157, 650041 Kunming, Yunnan, P.R. China \\ Telephone: $\quad$ (86871) $3161899,3162071,3167804$ \\ Fax: $\quad$ (86871) 3165698 or 3189198
Yunnan Province Planning Commission
Main Contact: $\quad$ Li Wending
Address: $\quad$ Yanching Xian, Dong Feng Road, Kunming, Yunnan, P.R. China
Telephone: $\quad$ (86871) 3167598

\section{Yunnan Province Science and Technology Commission} \\ Main Contact: $\quad$ Fang Tao, Deputy Director, Industry and Development Division \\ Alternate Contact: $\quad$ Cao Daming, Project Officer, International Cooperation Division \\ Address: \\ S\&T Building 18th Floor, No. 110 Beijing Road, 650051 Kunming, \\ Yunnan, P.R. China \\ Telephone: $\quad$ (86871) 3135996 \\ Fax: $\quad$ (86871) 3136444
}

\title{
Legal Environment
}

\section{General Overview}

Most policies in Yunnan are the same as those offered by the central government. However, the local government does have its own policies to encourage renewable energy development. In theory, the local government also encourages foreign investment; however, it still needs to control the return on investment and whether or not the project fits in the overall provincial plan. Nonetheless, practically all renewable energy projects fit within Yunnan's current plans.

According to the latest plan, which has yet to be approved by Beijing, policies to encourage renewable energy development should be implemented. However, current government restructuring has muddled the process. There is confusion amongst local government officials as to what these policies should be and which agency would have the responsibility to implement them. One part of the plan in which there is no confusion is the reform of the energy sector within Yunnan. By the end of 1999, power generation will be separated from the local utility's responsibilities. Presently, all power generation is owned primarily by the utility. This new reform will ensure fair competition amongst independent power producers. 


\section{Project Approval Process}

Yunnan has attempted to make the project approval process more transparent for foreign enterprises. The project must be approved by the same agencies as that of other provinces. However, the local ETC works closely with the local planning commission to expedite this process. Both entities must approve the project; however, the foreign enterprise or JV does not have to approach both agencies separately to get approval. The local ETC will assist the JV or foreign enterprise in moving the project plan to the correct personnel within the local planning commission.

In addition, the local ETC will assist foreign enterprises by introducing them to their Chinese counterparts, after which the two entities will work together on the Project Concept Document. Once that document is completed, the enterprise simply submits it to the local ETC, after which it will automatically move through the internal processes of both the ETC and the planning commission.

\section{Subsidies for Rural Energy Development}

The provincial government, principally the local EC, offers a total of 6 million RMB (\$729,000 U.S.) per year to subsidize the development of renewable energy in the countryside. These subsidies go primarily to bioenergy systems because these are the least expensive and most dominant systems in the rural areas. However, these subsidies are available for all types of renewable energy technologies.

\section{Preferential Taxation Rates for Foreign-Funded Enterprises}

Foreign-funded enterprises established in the province are exempted from local income tax. Foreignfunded enterprises established in areas such as Kunming Ruili, Wanding, and Hekou will be taxed at a $24 \%$ income tax rate. A foreign-funded enterprise established within the Kunming Dianchi tourist resort area will also be taxed at a $24 \%$ rate. A high-technology enterprise established by foreign entities in Kunming's Hi-New-Tech Development Area will be taxed at a $15 \%$ rate.

\section{Land Use Fee Reduced or Eliminated}

Environmentally beneficial projects can qualify for either a reduction or an elimination of the land use fee. This depends on the type of project, but is most likely negotiable.

\section{Surveyor's Rights}

If a potential developer is the first to survey a renewable resource such as geothermal, wind, or solar power, that entity will have the first right to develop that resource. For example, there is a large geothermal site in western Yunnan. A German company has been doing a survey where it has drilled two wells. Because it was the first to survey the resource, the company now has the sole right of developing it.

\section{Beneficial Loans}

Environmentally friendly firms, such as renewable energy companies, are eligible for interest reimbursement. The company must first receive a loan from a commercial bank. After the project is completed, half of the interest is reimbursed to the firm through a system set up by the Ministry of Finance. 


\section{Environmental Policies}

Because Yunnan has a diversity of minorities, each region within Yunnan has rights to legislate its own jurisdiction. For example, in the Dali region, the famous Lake Erhai is protected by local legislation. The legislation states that no new polluting entity may be established near the lake. Existing companies that pollute must either move or pay hefty fines.

\section{Competitive Environment}

\section{Overview of Renewable Energy Technologies}

\section{Bioenergy and Biomass Utilization}

Bioenergy is one of the principal renewable energy resources in Yunnan. There are 83 sugar mills in the province, 81 of which have an installed capacity of $1.5 \mathrm{MW}$ of electrical capacity. The remaining two have $3 \mathrm{MW}$ each of installed generating capacity. This electricity is solely for the use of the mill and a negligible amount is sold back to the utility. So far, only bagasse is used for electricity production.

Biogas is also produced from crop waste. This gas, like that made in other provinces, is primarily used for heating and cooking in the rural areas. There are no plans to use biogas for centralized systems such as those in Jilin.

\section{Tobacco Waste for Energy Production}

Tobacco is one of the largest industries in Yunnan. The average tobacco production in the province is more than 2 million tons, not including the stem of the plant. Last year, production jumped $25 \%$ to 2.5 million tons. Currently, the waste of the tobacco plant is not used for any energy production, but is considered to be a good biomass resource.

In 1996, a German company, INTERPARK, offered the technology to gasify the tobacco stem to produce electricity. Although the Chinese passed on the offer because they believed that the technology was too costly, government officials indicated that they would like to use this resource as soon as the technology becomes more cost effective.

\section{Wood Use for Energy Production in Rural Areas}

The Greenification Section of the Provincial Forest Bureau has a program to harvest wood for rural energy use. The plan is designed to increase production of firewood for the rural population. Currently, total consumption is 25 million $\mathrm{m}^{3}$ per year. There are no facilities to process this wood to gas or to another clean-burning fuel; the wood is burned directly for heating and cooking.

\section{Problems in Developing Bioenergy Resources}

There are other kinds of biomass resources with the potential for exploitation. The problem is that most of the usable biomass resources are on the fringes of the province. For example, most of the resource is on China's border with Vietnam or on the provincial borders with Tibet. These areas are very remote and the economies very backward, and are therefore not seen by investors as worthwhile places to develop and invest either money or technology. 


\section{Geothermal Utilization}

Yunnan has some of the richest geothermal resources in the country. The majority of the known geothermal resource can only be used for tourism and heating. However, Yunnan has some of the best resources in China for electricity production.

The province is split into two distinct regions along the Jinshjiang-Diancang Mountain-Honghe fault line, which runs in a north-south direction. These two regions contain 822 known springs with temperatures above $250^{\circ} \mathrm{C}$. Of those, more than $40 \%$, or about 350 springs, have temperatures in excess of $400^{\circ} \mathrm{C}$.

Western Yunnan Geothermal Resource

Western Yunnan contains some of the best-known medium- and high-temperature geothermal resources in all of China. In this region, there are 559 thermal areas with water temperatures above $250^{\circ} \mathrm{C}$. Within this group, there are 17 clusters that have temperatures over $950^{\circ} \mathrm{C}$. These clusters are mainly located in the areas outlined in the following table.

Table 10. Known Geothermal Resources in Western Yunnan

\begin{tabular}{|l|c|c|c|c|}
\hline \multicolumn{1}{|c|}{ Thermal Water Active Zone } & Boiling Spring & Hot Spring & Thermal Spring & Total \\
\hline Tengchong-Gaoligongshan & 6 & 87 & 98 & 191 \\
\hline Baoshan-Menglian & 0 & 67 & 54 & 121 \\
\hline Lincang-Jinghong & 10 & 48 & 48 & 106 \\
\hline Lanping-Simao & 0 & 24 & 51 & 75 \\
\hline Jianchuan-Siaguan-Jinping & 1 & 21 & 44 & 66 \\
\hline Total & 17 & 247 & 295 & 559 \\
\hline Percentage (\%) & 3 & 44 & 53 & 100 \\
\hline
\end{tabular}

Source: Yunnan Science and Technology Commission

These thermal hot springs, compared to those in the eastern part of Yunnan, are characterized by their high temperature and amount of heat flow. However, the single resources are also characterized by smaller water flows.

The top 24 hydrothermal systems above $1,500^{\circ} \mathrm{C}$ have the potential of producing approximately 548.2 MW of electricity, which is equal to 44 Mtce. These fields are broken into more detail in Table 11. 
Table 11. Total Energy Potential of Top 24 Sites in Western Yunnan

\begin{tabular}{|l|c|c|c|}
\hline $\begin{array}{c}\text { High-Temperature Hydrothermal } \\
\text { Active Zone }\end{array}$ & $\begin{array}{c}\text { Number of } \\
\text { Hydrothermal } \\
\text { Systems }\end{array}$ & $\begin{array}{c}\text { Heat Energy of } \\
\text { Thermal Reservoir } \\
\text { (EJ) }\end{array}$ & $\begin{array}{c}\text { Electricity Potential } \\
\text { (MW) }\end{array}$ \\
\hline Tengchong-Gaoligongshan & 9 & 25.31 & 474.35 \\
\hline Lincang-Jinghong & 11 & 14.24 & 57.37 \\
\hline Jianchuan-Xiaguan-Jinping & 4 & 5.59 & 22.27 \\
\hline Total & 24 & 45.14 & 548.20 \\
\hline
\end{tabular}

Source: Yunnan Science and Technology Commission

As indicated in the table above, the Tengchong region alone accounts for the majority of the potential electricity-producing resources. Table 12 provides more detail for that region.

Table 12. Thermal Energy Resources of High-Temperature Water Systems in Tengchong

\begin{tabular}{|l|c|c|c|c|c|c|c|}
\hline $\begin{array}{c}\text { Thermal Water } \\
\text { System }\end{array}$ & $\begin{array}{c}\text { Temp. } \\
\left({ }^{\circ} \mathrm{C}\right)\end{array}$ & $\begin{array}{c}\text { Area } \\
\left(\mathrm{km}^{2}\right)\end{array}$ & $\begin{array}{c}\text { Depth } \\
(\mathrm{km})\end{array}$ & $\begin{array}{c}\text { Heat Storage } \\
(10 \mathrm{EJ})\end{array}$ & $\begin{array}{c}\text { Energy } \\
\text { Outlet } \\
(10 \mathrm{EJ})\end{array}$ & $\begin{array}{c}\text { Usable } \\
\text { Energy } \\
\text { Outlet } \\
(10 \mathrm{EJ})\end{array}$ & $\begin{array}{c}\text { Potential } \\
\text { Electricity } \\
(\mathrm{MW} \text { x 30 yrs })\end{array}$ \\
\hline Liong Pu & 197 & 4.5 & 1.5 & $4.05 \pm 1.84$ & 1.01 & 0.227 & 95.8 \\
\hline Re Hai & 230 & 8.5 & 1.5 & $9.21 \pm 3.46$ & 2.3 & 0.553 & 233.5 \\
\hline Rui Dian & 160 & 3.2 & 1.5 & $2.19 \pm 1.13$ & 0.55 & 0.112 & 47.2 \\
\hline Penzhi Hua & 187 & 2 & 1.5 & $2.25 \pm 0.94$ & 0.56 & 0.117 & 49.4 \\
\hline Hei Shihe & 145 & 2 & 1.5 & $1.26 \pm 0.38$ & 0.32 & 0.057 & 23.9 \\
\hline
\end{tabular}

Source: Yunnan Science and Technology Commission

East Yunnan Geothermal Resource

Although there are vast geothermal resources in the eastern part of Yunnan, none are known to be high temperature. There are a total of 263 known thermal springs in this region, all with temperatures lower than $90^{\circ} \mathrm{C}$. 186 springs have temperatures between $25^{\circ}$ and $40^{\circ} \mathrm{C}$. Only 14 springs have temperatures between $60^{\circ}$ and $90^{\circ} \mathrm{C}$. Many of these reservoirs are at depths of approximately $200 \mathrm{~m}$. However, some may be at depths of $1,000 \mathrm{~m}$.

Because the majority of these resources are low temperature, relatively little attention has been paid to this region of Yunnan. However, evaluations based on the thermal water flow of springs and drilling have indicated that the total discharge of this resource is 204 million tons, yielding an annual heat output of $0.015 \mathrm{EJ}$.

\section{Hydropower Utilization}

Hydropower is one of Yunnan's main sources of large-scale electricity. 4,333 MW out of a total 6,368 MW installed capacity comes from hydropower plants. For the Ninth Five-Year Plan, the provincial government has plans to install an additional $833 \mathrm{MW}$ of hydro capacity. Despite the fact that there is a surplus of energy during the rainy season, the provincial government plans to build even more hydropower plants in anticipation of continued economic growth throughout the region. Plans for the Tenth Five-Year Plan (2000-2005) call for an additional 1,450 MW to be installed. 
The Yunnan Power Bureau is the main developer of these proposed projects. However, the company typically partners with other Chinese entities in order to raise the appropriate capital. Other projects, in addition to those in the five-year plans, call for several thousand more megawatts of installed hydropower plants beyond 2005. However, the development of these projects depends heavily on the state of Yunnan's neighboring countries, because they would be buying the bulk of the power. It is hoped that the current economic crisis in Southeast Asia will be resolved by the time construction is set to begin. (See the "Yunnan Provincial Power Bureau" section for more details on these projects.)

\section{Solar Power Utilization}

Solar energy technologies are widely used throughout Yunnan Province, as it has some of the best solar resources in the country. Nevertheless, the market for PV technology in the province is relatively small, even though Yunnan has some of the largest PV manufacturers in China. Most manufacturers sell their products to other parts of the country, especially western China, where large numbers of PV systems are being installed.

The solar technology that has been fully commercialized, and exists in practically every household in most major cities throughout the province, is solar hot-water heaters. Marketing this technology has shifted from consumer-type marketing in which individual households buy the products to industrial-type marketing, in which large institutions are being sold multiple or industrial-sized systems.

Currently, there are approximately 150 enterprises involved in manufacturing or assembling solar water heaters. However, the bulk of these enterprises are very small and merely assemble and sell the various components of the systems. Only three or four larger enterprises in Yunnan actually manufacture all the parts of the systems and control the majority of the market.

\section{The Potential for PV}

According to the provincial government's plan, all villages throughout Yunnan will be electrified by 2000. Currently, about 1 million households remain without electricity, although plans call for the extension of the main grid to reach the vast majority of these households. However, government officials acknowledge that at least $1 \%$ of those households will need to be electrified in other ways. They plan to use PV systems to electrify this potential 10,000-household market. The provincial power bureau will implement this project.

There are many other PV and solar water heater projects that are important to the Yunnanese. These projects are described in detail in the "Renewable Energy Company Profiles" section below.

\section{Wind Energy Utilization}

Yunnan has very little in the way of wind resources. The main resources are in the northern mountainous region, where the population is extremely sparse and the demand for energy very small. Currently, only 230 small wind turbines have been installed in the province. These systems range from 100 to $150 \mathrm{~W}$. Wind speeds in this region range between 3 and $6 \mathrm{~m} / \mathrm{s}$ at $10-\mathrm{m}$ heights.

Dali has very good wind resources during the fall and spring. However, during the winter and summer, there is virtually no wind. Because winter and summer are the rainy seasons, most of the energy during this period could come from micro-hydro systems. 
Dali Wind Turbine Manufacturing Company (DWTM)

According to the local power bureau, there was a small wind turbine manufacturer located in the Dali region. The company, which manufactures 50-200-W turbines, is state owned and falls under the jurisdiction of the Agricultural Machinery Bureau. The company was previously an agriculturalmachinery factory, but was converted to a wind turbine manufacturer 10 years ago. Because the factory is involved with renewable energy, the local economic commission provided between 200,000 and $300,000 \mathrm{RMB}(\$ 25,000-\$ 35,000$ U.S.) to start the company.

Although DWTM controls the market in this small tourist region, this is not considered to be a very profitable situation because the market in that region is very limited and not expected to grow significantly anytime soon. So far, the company has manufactured 50 200-W turbines. Local government officials are not sure whether the company intends to expand or partner with a foreign company. However, because Yunnan acts as a gateway to other Southeast Asian countries, there is potential for this to occur.

\section{Yunnan Geothermal Development Plan for 1996-2010}

\section{Geothermal Plan Guidelines}

- Because geothermal exploration is still in its infancy, development must rely on both science and technology, and research must be combined with utilization.

- Top priority should be given to high-temperature geothermal resources for electricity production. At the same time, comprehensive utilization of medium- and low-temperature resources should be explored in order to suit local living conditions.

- International exchange and cooperation should be strengthened in order to advance the utilization of modern technology and equipment.

- Foreign investment could be encouraged by implementing favorable incentive policies.

- More emphasis should be placed on personnel training.

\section{Geothermal Plan Objectives}

The plan will be implemented in two stages. The first stage coincides with the country's Ninth Five-Year Plan (1996-2000). The second stage of the plan covers 2001 through 2010.

\section{$\frac{1996-2000}{0.5 e t u p}$}

- Set up a MW-sized power station, establish a geothermal "vacation district," and make preparations for a geothermal research center.

$\underline{2001-2010}$

- After the first power station is functioning properly, a second power station will be set up. Finalize the development of the geothermal resource center.

- Set up a high-temperature power-generating research base in western Yunnan.

- Set up a research base for the comprehensive utilization of geothermal resources in eastern Yunnan.

- Make both research bases part of the research center for geothermal exploration. 


\section{Geothermal Plan Specifics}

1. Increase power generation from high-temperature geothermal resources

- Carry out project in the Rehai, Tongcheng field. (See Appendix F for a detailed description of this project area.)

- Set up a 15-MW power station.

- After success of first project, replicate project to other counties such as Longlin, Lianghe, and Yunxian.

2. Advance exploration of high-temperature fields (which is extremely expensive). Therefore, during 1996-2000, tentative exploration should be conducted in Yunxian and Longlin counties.

3. Establish scientific "vacation district".

- Because Yunnan is famous for its natural scenery and multi-ethnic cultures, tourism must continue to be cultivated. Development of geothermal resources for recreation and health care is essential for steady economic growth in the province. The areas for this development will be centered around Tengchong and spread outwards to Longlin, Mangshi, and Ruili.

4. Advance geothermal research

- Set up a research center during 1996-2000 in Kunming with a subsidiary unit and power generation research base in Tengchong.

- Build the research center for comprehensive utilization of geothermal resources in Kunming by 2000.

- During 1996-2000, achieve successes in the processing and aquaculture industries.

5. Promote international cooperation to establish a geothermal research center, with the intent of gaining influence in this field throughout all of Asia.

- Research high-temperature geothermal resources for power generation and the comprehensive utilization of lower-temperature resources.

\section{Economic Environment}

Yunnan Province is heavily dependent on the tobacco, mining, and tourism industries. The economic crisis in China has affected Yunnan's tourism and mining industries and many layoffs are expected. Chinese officials believe that there are many positive outcomes that will occur because of these layoffs. For example, industries will become much more efficient and better able to compete in the international market. Training programs have been set up for the unemployed and subsidies are given to those who attend these programs.

The following table outlines the current economic situation in Yunnan:

Table 13. Average Income and Cost of Living Per Capita in Yunnan in 1997

\begin{tabular}{|l|c|c|c|}
\hline Population & $\begin{array}{c}\text { Average Wage } \\
\text { (\$/year U.S.) }\end{array}$ & $\begin{array}{c}\text { Cost of Living } \\
\text { (\$/year U.S.) }\end{array}$ & $\begin{array}{c}\text { Registered } \\
\text { Unemployment }\end{array}$ \\
\hline Urban & 900 & 720 & $2,910,000$ (total) \\
\hline Rural & 291 & 233 & \\
\hline
\end{tabular}

Source: Center for Renewable Energy Development 


\section{Cost of Electricity}

Yunnan's energy price is the third lowest in the country because of its GDP, which is lower compared with that of its more developed neighbors. This price is determined by the Provincial Pricing Bureau and based on the consumer's purchasing power. However, as the province grows economically, this price should increase. As indicated in Table 14, most of the energy in Yunnan is consumed by the industrial sector, which accounts for about $75 \%$ of the total energy consumption of the province. Because many of the major agricultural producers generate and consume their own power, statistics on their consumption are not available.

Table 14. Breakdown of Power Sectors in Yunnan

\begin{tabular}{|l|c|c|}
\hline \multicolumn{1}{|c|}{ Sector } & $\begin{array}{c}\text { Electricity Consumption } \\
\text { (Million tce) }\end{array}$ & $\begin{array}{c}\text { Electricity Price } \\
(\$ / \mathrm{kWh} \text { U.S. })\end{array}$ \\
\hline Agricultural & $\mathrm{N} / \mathrm{A}$ & 0.04 \\
\hline Industrial & 15.62 & 0.09 \\
\hline Institutional & 1.48 & 0.04 \\
\hline Residential & 2.2 & $0.04-0.06$ \\
\hline
\end{tabular}

Source: Center for Renewable Energy Development

\section{Increasing Costs of Coal, Leading to the Development of Other Energy Sources}

Thermal power plants have typically been seen as the most economic power plants to develop. Now, micro-hydro and other energy resources are less expensive than coal. Contributing factors include reductions in interest rates (from $15 \%$ to $10 \%$ ), development costs, and civil works costs.

More importantly, however, is the fact that transportation fees for importing coal from one province to the other have increased, making coal less competitive. In addition, the Environmental Protection Bureau has been very diligent in levying fines on polluting thermal power plants. All of these factors have put increasing pressure on the costs of producing coal-fired electricity and led to more interest in developing other energy resources.

\section{Geographic Environment}

Yunnan Province has some of the most complex terrain in the country. The western part of the province is characterized by the Rehai, Tengchong Geothermal Field. (Please refer to Appendix F.) The northern region is mountainous whereas the southern region of the province shares a border with Myanmar (Burma) and Vietnam.

The climate is generally mild year-round. The rainy season lasts between June and September; however, the temperature rarely exceeds $25^{\circ} \mathrm{C}$ and rarely falls below $10^{\circ} \mathrm{C}$.

\section{Technological Environment}

Yunnan's transportation infrastructure is just beginning to develop. There are two main roads that connect Kunming with the northern and southern regions, as well as the eastern and western regions, of the province. However, major highways are in the process of being built because of the International Horticulture Exhibition, which will take place in 1999. Major efforts are being made to continue 
upgrading the highway, communication, and electricity transmission systems before the Exhibition takes place. Current communication systems are sufficient, however, in the major cities.

Kunming harbors some of the major institutions for solar and geothermal energy research in the country. This is exemplified by the fact that there are so many solar water heater manufacturers in the province. Despite the combined experience in solar and geothermal energy, funding has kept the technologies well behind those of the wealthier, industrialized nations. Because of this, production lines are outdated and manufacturing capabilities are hindered.

\title{
Sociocultural Environment
}

Because it shares a large border with neighboring Myanmar, Laos, and Vietnam, Yunnan has a variety of different cultures, which is reflected in the mixture of customs and beliefs that extends throughout the entire province. Much of the province's population lives in the rural and mountainous areas in the outlying areas beyond Kunming.

Despite the many different cultures, renewable energy is deeply rooted in the everyday practices of the people. Solar water heaters are installed on virtually every home in the major cities. Both large-scale and micro-hydro systems provide the bulk of the power for the province. Bioenergy resources are used by most rural inhabitants for cooking, heating, and lighting. Geothermal power is instrumental in the growth of the tourism industry not only for its therapeutic waters but also for its natural beauty. Geothermal resources are also critical for the province's agricultural industry for use in drying crops such as tobacco, coffee, and tea.

Because of the variety of different applications that coincide with the livelihoods of the populace, attitudes towards renewable energy resources are very positive. Government officials believe that the Yunnanese would be willing to pay slightly more for renewable energy products than for conventional products. However, cost is a significant factor in many of the consumers' decisions.

\section{Renewable Energy Company Profiles}

\author{
Global Solar Energy Equipment Company (GSEE) \\ Main Contact: $\quad$ Zhu Xiangguang, General Manager \\ Telephone: $\quad$ (86871) 8312161 \\ Alternate Contact: $\quad$ Duan Ming Yuan, Deputy Manager \\ Telephone: $\quad$ (86871) 8312161 \\ Alternate Contact: $\quad$ Luo Ying Zhong, Deputy Manager \\ Telephone: $\quad$ (86871) 8181145
}

Alternate Contact: $\quad$ Long Tian Fu, Deputy Director of Party Commission for GSEE

Telephone: $\quad$ (86871) 8312155

GSEE has been operating for more than 20 years and has been producing solar water heaters since the early 1980s. Their products have won quality certification by both domestic and international agencies. However, the certifying agencies are unknown. GSEE is a state-owned company and was converted to its present form from a military factory. Currently, GSEE distributes its product to 19 provinces and 
eight different countries. Some of the countries that they currently market to are Libya, Vietnam, Malaysia, Singapore, Hong Kong, and Camaroon, as well as other African countries.

The company has been growing rapidly. By the end of 1988, GSEE's production capability reached $20,000 \mathrm{~m}^{2} /$ year of solar thermal collectors. In 1996, the company received a 3.5 million RMB loan $\left(\$ 425,274\right.$ U.S.) to increase this production capacity to $100,000 \mathrm{~m}^{2}$ of solar thermal collectors. In 1997 , the company sold $40,000 \mathrm{~m}^{2}$ of solar thermal collectors and was on its way to selling 70,000 $\mathrm{m}^{2}$ in 1998 . Currently, GSEE holds the largest portion of the Yunnan market for solar water heaters, with a 30\% market share. GSEE is among the top five solar water heater companies in the country, with a $10 \%$ market share in all of China. The company maintains total control of its R\&D, manufacturing, distribution, marketing, and servicing facilities.

\title{
Goals and Objectives
}

GSEE wants to make the best use of solar energy for the benefit of the Chinese mainland. The main goal of the company is to maximize their production capability and sell $100,000 \mathrm{~m}^{2}$ of solar collectors per year by 1999. Management would eventually like to expand their product lines to include other solar technologies such as photovoltaics, and are seeking foreign partnerships to realize that goal. GSEE is also looking to foreign partners to help the company expand its market to include foreign countries other than the ones listed above.

\section{Pricing}

Prices depend on the quality of the products. For example, some products are made of aluminum, copper alloy, and stainless steel. The prices range from 1,800-2,600 RMB/unit (\$218-\$315 U.S.) for a 3-4 $\mathrm{m}^{2}$ system.

\author{
Kunming Xinying Solar Energy Facility Plant (KXSE) \\ Main Contact: $\quad$ Mr. Zhu, President \\ Alternate Contact: $\quad$ Chen Shen, Assistant Factory Director \\ Address: \\ Telephone: \\ 8th Group, North Part, Xinying District, 650225 Kunming, Yunnan, P.R.China \\ Fax: \\ (86871) 3326168 \\ (86871) 3342828
}

KXSE is a privately owned company that began operations in 1990. The company deals primarily in the manufacture and distribution of solar water heaters. KXSE has been extremely successful in penetrating Yunnan's market with a 20\% share. It has centered its marketing efforts in Kunming City, where the majority of Yunnan's market is located.

\section{Goals and Objectives}

In the short term, KXSE would like to pay more attention to its new technology so that the company can begin to expand its market. Current technology in China is at least 10 years old. Two other companiesQinghai University Solar Electric Manufacturing Company and Beijing Solar Energy Research Institute - manufacture the bulk of solar collectors in China. Qinghai University manufactures vacuumtube technology, and Beijing Solar Energy Research manufactures plate technology. By cultivating newer technology, KXSE will be set apart from the rest of its competition. In the longer term, the company would like to expand its product line to other solar technologies such as photovoltaics. 


\section{Marketing Strategy}

Part of KXSE's success has been attributed to its unique marketing approach. KXSE markets its product to major developers in Kunming City. Each year, more than $400,000 \mathrm{~m}^{2}$ is developed for living quarters. The company has developed a strategic relationship with Best Construction Company, the largest apartment developer in Kunming, to pre-install solar water heaters on all of Best's developments. The cost of the water heaters is absorbed into the entire cost of the apartment. This relationship resulted in a total of $20,000 \mathrm{~m}^{2}$ of solar collectors sold in 1997. As of mid-1998, the additional $20,000 \mathrm{~m}^{2}$ had been sold through Best Construction.

The company plans to continue operating with this strategy but acknowledges that it will not be sustainable. The problem is that the government controls the amount of construction growth each year. It is inevitable that the government will limit the amount of housing development as the market becomes too saturated. KXSE has very little interest in expanding the market for its current products because the technology is very simple and can be copied too easily. Expanding the market would limit the amount of control the company has over counterfeiters.

\section{Products}

The current products sold are of a standardized plate technology. KXSE manufactures three sizes of solar water-heating systems:

1. Small: $\quad 4-\mathrm{m}^{2}$ solar collector with $300-\mathrm{kg}$ tank

2. Medium: 6- $\mathrm{m}^{2}$ solar collector with $600-\mathrm{kg}$ tank

3. Large: $\quad 12-\mathrm{m}^{2}$ solar collector with $1-\mathrm{m}^{3}$ tank

The price of these water heaters is approximately $600 \mathrm{RMB} / \mathrm{m}^{2}\left(\$ 73 / \mathrm{m}^{2} \mathrm{U} . \mathrm{S}\right.$.).

KXSE has developed new technology for which it is seeking a patent. The technology is focused on a different structure of the plates that make up the collector. This new structure will make it more difficult to replicate. Also, the new technology will be more efficient while utilizing regular glass in order to keep costs competitive.

\section{Prospects for Foreign Partnership}

KXSE is seeking investment assistance in order to purchase a new PV product line. Investment can come in the form of cash or equipment. In addition, the company would like help with management and processing techniques. The company would also welcome partners to assist in manufacturing advanced materials such as high-tech glass.

The company is willing to share control of the business relative to the amount of investment made. For example, if a foreign entity invests $51 \%$ of the value of the company, it would control $51 \%$ of the company. However, similar objectives for the direction of the company and for the amount of profits to be made are necessary for KXSE to enter into any partnership. 


\section{Yunnan Provincial Electric Power Bureau}

Main Contact:

Alternate Contact:

Alternate Contact:

Address:

Telephone:

Fax:
Xie Kunsheng, Deputy Director/Deputy General Manager

Zhen Xinlian, Senior Engineer, Planning Department

Zheng Waisheng, Engineer, Planning Department

Dongfendong Road No. 157, 650041 Kunming, Yunnan, P.R. China

(86871) 3161899,3162071 or 3167804

(86871) 3165698 or 3189198

The Provincial Power Bureau is responsible for developing large-scale hydro projects. The agency is also responsible for negotiating and signing any PPAs in which any foreign entity would engage. In addition, the agency administers any rural electrification programs for the province. The following hydro projects are open to foreign partners and investors:

\section{Xiaowan Project}

Project plans call for a 4,200-MW hydropower plant. The project is expected to begin in 2002, with the first turbine to be operational in 2009. The drop is 230 meters and the distance from top to bottom is 292 meters.

Four domestic companies or agencies have been invited to invest in this project. The following are the potential domestic investors:

1. State Power Corporation

2. Yunnan Provincial Power Bureau

3. Yunnan Hongta Group (tobacco company)

4. Yunnan Investment Company

Total investment in this project is expected to reach 34.2 billion RMB ( $\$ 4.16$ billion U.S.). The Japanese Overseas Economic Cooperation Fund (OECF) has committed 0.8 billion RMB (\$97.2 million U.S.) toward the financing of this project.

\section{Other Hydro Projects}

A couple of hydro projects near the southern border of the province are also planned. These projects are aimed at the Southeast Asian markets. However, because of the economic crisis in that region, much of the investment has dried up.

The first project is a 1,250-MW hydro installation on the Mekong River. Another 1,500-MW project is being planned in Jinghong. The Jinghong project's energy will be for the Thailand market. Unfortunately, most of the investment for this project was to come from Thai sources. This has stalled progress; however, the power bureau is still focusing much attention on the development of this project.

In addition to these large-scale hydro projects, there are several medium-scale projects in the planning stage throughout Yunnan. For a list of these projects, please contact the power bureau.

\section{Yunnan Geothermal Development Company (YGDC)}

Main Contact: $\quad$ Zhu Jianyong, Managing Director

Address:

Telephone:

Fax:

(86871) 3145103 or 3145101

(86871) 3145101 
YGDC is a state-owned company with five primary shareholders. The provincial SPC controls the largest share of the company with $32 \%$. Other owners include companies controlled by the Local Planning Commission (22\%), the Oil Survey Bureau of Hunan, Guizhou, and Guanxi (22\%), and the Financial Bureau of Yunnan (22\%); the remaining 2\% is controlled by Tongcheng County.

\section{Goals and Objectives}

Although the company is the only geothermal developer in Yunnan, it lacks funds to explore the rich resources of the province. Because of this lack of funds, YGDC has limited its scope to the Tongcheng region, where there are known high-temperature resources. YGDC intends to drill two new wells and generate electricity from those wells by 2000 .

\section{Prospects for Foreign Partnership}

\section{Tongcheng Project}

YGDC has already invested 5 million RMB $(\$ 608,000$ U.S.) for drilling one of three wells (called ZK201). So far, the temperature at a depth of 1,200 meters is $153^{\circ} \mathrm{C}$; however, the company is still unsure whether or not there is a resource. Drilling began in February 1998 but has since stopped due to lack of funds. YGDC would like to drill two additional wells to depths of 1,700 meters, but needs foreign assistance to do so. It is estimated that the temperatures at 1,700 meters are about $220^{\circ} \mathrm{C}$. The current design for the intended power plant is for resources at or above $180^{\circ} \mathrm{C}$. If the company finds a resource, it wants to develop at least $10 \mathrm{MW}$.

Many foreign companies have explored the option of participating in this venture, but none has committed to the project as of yet. A consortium from four European countries (Norway, Iceland, Sweden, and Denmark) has recently offered soft loans to the Chinese. However, negotiations are in the beginning stages and it is unknown when these finances will come through. Nevertheless, the Chinese expressed a willingness to share in the investment and are willing to do another survey of the area's chemical composition.

\section{Current Obstacles}

Obviously, the main problem is financing. However, the Chinese are currently interested in developing a small power plant due to the lack of demand in the region. Very few foreign companies are willing to risk exploration towards the development of such a small plant. In a county of approximately 570,000 people, average consumption is only about $571 \mathrm{kWh}$ per capita/year. As demand rises in the region and as new transmission lines are built that can reach more metropolitan areas, foreign interest in the area should increase.

\section{Yunnan Semiconductor Device Factory}

Main Contact: $\quad$ Zhu Huimin, Executive Vice-Director

Alternate Contact: $\quad$ Qiu Diming, Vice-Director (Tel. +5317276)

Address:

Telephone:

Fax:
24 Jianshe Road, 650033 Kunming, Yunnan, P.R. China

(86871) 5321431

(86871) 5337279

Yunnan Semiconductor specializes in solar cell manufacturing. However, the company also manufactures its own controllers and inverters. Currently, the company has the capacity to manufacture $500 \mathrm{~kW}$ of monocrystalline solar cells. The primary market for these cells is the domestic telecommunications market. However, some PV modules are sold to Japan and various other Southeast Asian countries. 


\section{Goals and Objectives}

The following are Yunnan Semiconductor's goals and objectives:

1. Partner with a foreign company to expand its technological capability and participation in the international market.

2. Return to the off-grid solar home system market to meet the demand of those without access to the grid.

3. Even after the increase in production to $1.5 \mathrm{MW}$ per year in 2000, company officials believe the new capacity will not be sufficient to meet the demand. Therefore, officials would like to further increase that to at least $5 \mathrm{MW}$ per year and are looking to foreign investors to help them achieve that goal.

4. Currently, the international market accounts for only $10 \%$ of Yunnan Semiconductor's sales. The company would like to partner with either a U.S. or European company to penetrate the international market and become a dominant player in the industry.

5. Yunnan Semiconductor has given priority to setting up a silicon-manufacturing plant for use in its PV products. Officials are currently seeking foreign partnerships to achieve this goal.

Future Plans

Yunnan Semiconductor plans to expand its production capacity to $1.5 \mathrm{MW}$ by 2000 . It is currently in the process of expanding this production with the financial assistance of the SETC. Once this expansion is complete, the company will be able to produce both monocrystalline and polycrystalline solar cells. The company will also produce both square and circular wafers.

In addition, the expansion will help the company solidify control of the market by increasing the commercial efficiency of the cells, making them the best in the country. Yunnan Semiconductor knows that the World Bank provides money for the commercialization of PV technology and is seeking ways to get involved in the current World Bank project in western China. Company officials are doing the preliminary work necessary to get involved in the project and are now discussing it with SETC officials.

The company uses a direct-sales method to distribute its product. However, Yunnan Semiconductor plans to develop an in-country distribution network of reliable retailers who are skilled in PV technology to increase sales.

\section{Market Prospects}

The company started producing its solar cells for the solar home systems market because there were so many unelectrified households in areas without access to the grid. As time passed, more product was sold to the telecommunications industry. Most of the company's market is located in the western part of China where the solar resources are considered to be excellent. Yunnan Province itself is not yet considered to be a very good PV market despite the province's good solar resource.

Yunnan Semiconductor has very little competition in China because there are only about four major PV manufacturers in the country. As a result, it dominates the Chinese market, controlling $40 \%$ of sales and production. Total income from this production line is approximately 20 million RMB/year (\$2.5 million U.S.). Currently, the company is manufacturing close to capacity and hopes to expand production in the very near future.

\section{Products}

As mentioned above, the company only manufactures monosilicon PV cells and the inverters and controllers that go with the systems. The standard-size modules range between 35 and $38 \mathrm{~W}$. Yunnan Semiconductor also manufactures smaller modules ranging between 8 and $18 \mathrm{~W}$. Typically, prices range between 40 and $45 \mathrm{RMB} / \mathrm{W}$ (\$4.86-\$5.47 U.S.). 
The company expressed little interest in developing other types of PV technology such as amorphous technology because company officials are not yet convinced that the efficiency of such modules can exceed 7\%. The current efficiency of Yunnan Semiconductor's modules ranges between 13.5\% and $14 \%$. Company officials predict that any technology with less efficiency has very little future in China.

Prospects for Foreign Partnership

Although Yunnan Semiconductor welcomes assistance to increase its production capability and product line, its number-one priority is to set up a silicon-manufacturing plant. This project has also been given priority status by the local ETC. It is hoped that at least 1,000 tons/year of silicon product will be produced by this new factory. Local government officials are willing to waive income taxes for the first three years. During years four through five, only $50 \%$ of the normal income tax rate would have to be paid. In addition, the foreign entity will be allowed to convert its profits to hard currency for repatriation.

Global Semiconductor Technology Corporation of the United States has already expressed interest. Unfortunately, approval has been held up in the SDPC. For more information on this project, contact either the local ETC or Yunnan Semiconductor. 
Appendices 


\section{Appendix A}

\begin{tabular}{|c|c|}
\hline & Beijing New Buildings Materials Co., Ltd. \\
\hline Address & $\begin{array}{l}\text { Xisanqi Deshengmenwai, Haidian District, } 100085 \text { Beijing, P.R. China } \\
\text { Tel.: (8610) 62913831 x308; fax: (8610) 62912658 }\end{array}$ \\
\hline Type of company & $\begin{array}{l}\text { Part state owned, part privately owned } \\
(70 \% \text { owned by group, } 30 \% \text { owned by stockholders })\end{array}$ \\
\hline Main contact & Wang Hongxi, Executive Director \\
\hline Type of products & $\begin{array}{l}\text { Building materials with intent to expand into PV modules manufacturing; } \\
\text { vacuum-tube solar water heaters. }\end{array}$ \\
\hline Price of products & $\mathrm{N} / \mathrm{A}$ \\
\hline Market share & $\mathrm{N} / \mathrm{A}$ \\
\hline Company's customers & Housing developers and individual households \\
\hline $\begin{array}{l}\text { Company's marketing } \\
\text { approaches }\end{array}$ & $\begin{array}{l}\text { They expect to start large-scale manufacturing of solar panels and break even } \\
\text { after 3-5-year period. They will develop and build pre-fab houses with solar } \\
\text { roofing and other solar building materials. }\end{array}$ \\
\hline Annual sales revenues & $\$ 85$ million U.S. \\
\hline $\begin{array}{l}\text { Estimate of market } \\
\text { potential for products } \\
\text { in country and abroad }\end{array}$ & - $3 \%-5 \%$ of all households on China's eastern coast \\
\hline $\begin{array}{l}\text { Business goals and } \\
\text { objectives }\end{array}$ & $\begin{array}{l}\text { - Set up PV panel manufacturing capability with modern production } \\
\text { facilities } \\
\text { Establish pilot project with pre-fab homes using solar technologies for } \\
\text { educational purposes } \\
\text { - Change philosophy of wealthy Chinese to being more environmentally } \\
\text { aware }\end{array}$ \\
\hline $\begin{array}{l}\text { Interest in working } \\
\text { with U.S. partners }\end{array}$ & $\begin{array}{l}\text { Willing to work with U.S. partners. Already have been in discussions with } \\
\text { U.S. and European companies such as BP Solar, Solarex, Atlantis, and } \\
\text { Mitsubishi. }\end{array}$ \\
\hline $\begin{array}{l}\text { Specific products and } \\
\text { services expected from } \\
\text { partnership }\end{array}$ & $\begin{array}{ll}- & \text { Management skill } \\
- & \text { Production lines } \\
\text { - } & \text { New technology }\end{array}$ \\
\hline
\end{tabular}




\begin{tabular}{|l|l|}
\hline & \multicolumn{1}{|c|}{ Beijing Solar Energy Research Institute } \\
\hline Address & $\begin{array}{l}\text { 3 Huayuan Rd., Haidian District, 100083 Beijing, P.R. China } \\
\text { Tel.: (8610) 62012881; fax: (8610) 62012880 }\end{array}$ \\
\hline Type of company & State owned \\
\hline Main contact & Li Zhongming, Associate Professor \\
\hline Type of products & Solar water heaters and PV cells \\
\hline Price of products & Solar water heaters range from \$176-\$250 U.S. \\
\hline Market share & Company executives claim a 30\% market share for China's solar water heaters. \\
\hline Company's customers & Individual households \\
\hline $\begin{array}{l}\text { Company's marketing } \\
\text { approaches }\end{array}$ & Direct sales \\
\hline Annual sales revenues & N/A \\
\hline $\begin{array}{l}\text { Estimate of market } \\
\text { potential for products } \\
\text { in country and abroad }\end{array}$ & $\bullet$ Solar water heaters: Over 700,000 $\mathrm{m}^{2}$ (\$87.5-\$210 million U.S.) \\
\hline $\begin{array}{l}\text { Business goals and } \\
\text { objectives }\end{array}$ & $\bullet \quad$ Expand into PV manufacturing by 2000 \\
\hline $\begin{array}{l}\text { Interest in working } \\
\text { With U.S. partners }\end{array}$ & Willing to work with U.S. partners \\
\hline $\begin{array}{l}\text { Specific products and } \\
\text { services expected from } \\
\text { partnership }\end{array}$ & $\bullet$ Management skill \\
\hline
\end{tabular}




\begin{tabular}{|c|c|}
\hline & Beijing Tianpu Solar Energy Industry Co., Ltd. \\
\hline Address & $\begin{array}{l}\text { Lucheng Industry Development District, Daxing County, } 102600 \text { Beijing, } \\
\text { P.R.China } \\
\text { Tel.: (8610) 69239699; fax: (8610) } 69239666\end{array}$ \\
\hline Type of company & Private \\
\hline Main contact & Li Xianhang, Chairman of the Board \\
\hline Type of products & Solar water heaters (vacuum tube) \\
\hline Price of products & $\mathrm{N} / \mathrm{A}$ \\
\hline Market share & $10 \%-15 \%$ of Chinese solar water heater market \\
\hline Company's customers & Individual households \\
\hline $\begin{array}{l}\text { Company's marketing } \\
\text { approaches }\end{array}$ & Direct sales \\
\hline \begin{tabular}{|l|} 
Annual sales \\
revenues
\end{tabular} & $\$ 27.1$ million U.S. \\
\hline $\begin{array}{l}\text { Estimate of market } \\
\text { potential for products } \\
\text { in country and } \\
\text { abroad } \\
\end{array}$ & - Solar water heaters: Over $700,000 \mathrm{~m}^{2}(\$ 87.5-210$ million U.S. $)$ \\
\hline $\begin{array}{l}\text { Business goals and } \\
\text { objectives }\end{array}$ & $\begin{array}{l}\text { To use the company's solar water-heating business as their cash cow and } \\
\text { diversify into manufacturing PV panels and other building materials } \\
\text { - Enter into eco-resorts using renewable energy technologies } \\
\text { Develop pilot project using solar energy in construction, agriculture, and } \\
\text { tourism. }\end{array}$ \\
\hline $\begin{array}{l}\text { Interest in working } \\
\text { with U.S. partners }\end{array}$ & Willing to work with U.S. partners. \\
\hline $\begin{array}{l}\text { Specific products and } \\
\text { services expected from } \\
\text { partnership }\end{array}$ & $\begin{array}{l}\text { - } \text { Management skill } \\
\text { - } \\
\text { - Techuipment and financing } \\
\text { Thical know-how }\end{array}$ \\
\hline
\end{tabular}




\begin{tabular}{|c|c|}
\hline & Guangdong Windpower Company \\
\hline Address & $\begin{array}{l}757 \text { Dongfeng Rd. E., } 510600 \text { Guangdong, P.R. China } \\
\text { Tel.: } 8620 / 87767888 \text { x23228; fax: } 8620 / 87302625\end{array}$ \\
\hline Type of company & $\begin{array}{l}\text { State owned by Guangdong Power Bureau, Provincial Planning Commission, } \\
\text { and State Energy Conservation and Investment Company }\end{array}$ \\
\hline Main contact & Chen Fengpan, General Manager \\
\hline Type of products & Wind farm development and wind turbine towers \\
\hline Price of products & $\mathrm{N} / \mathrm{A}$ \\
\hline Market share & $\begin{array}{l}\text { The company holds a virtual monopoly on wind farm development in } \\
\text { Guangdong. }\end{array}$ \\
\hline Company's customers & Provincial utility \\
\hline $\begin{array}{l}\text { Company's marketing } \\
\text { approaches }\end{array}$ & $\mathrm{N} / \mathrm{A}$ \\
\hline Annual sales revenues & $\mathrm{N} / \mathrm{A}$ \\
\hline \begin{tabular}{|l|} 
Estimate of market \\
potential for products \\
in \\
country and abroad \\
\end{tabular} & - 7,000 MW worth approximately \$7 billion U.S. \\
\hline $\begin{array}{l}\text { Business goals and } \\
\text { objectives }\end{array}$ & $\begin{array}{l}\text { - } \\
\text { - }\end{array}$ \\
\hline $\begin{array}{l}\text { Interest in working with } \\
\text { U.S. partners }\end{array}$ & $\begin{array}{l}\text { Willing to work with U.S. partners. However, they are unwilling to purchase } \\
\text { U.S. turbines without tied-aid attached to the sale. }\end{array}$ \\
\hline $\begin{array}{l}\text { Specific products } \\
\text { and services } \\
\text { expected from } \\
\text { partnership }\end{array}$ & $\begin{array}{ll}- & \text { Management skill } \\
\text { - } & \text { Equipment and financing } \\
\text { - } & \text { Feasibility analysis }\end{array}$ \\
\hline
\end{tabular}




\begin{tabular}{|l|l|}
\hline & \multicolumn{1}{|c|}{ Guangdong Institute of Energy Conservation } \\
\hline Address & 81 Central Martyrs Rd., 510070 Guangdong, P.R. China \\
\hline Type of company & State owned under Chinese Academy of Science \\
\hline Main contact & Chen Guoju, Director \\
\hline Type of products & Please see following pages for complete listing \\
\hline Price of products & N/A \\
\hline Market share & $\begin{array}{l}\text { Many of their products have yet to be commercialized. Solar water heater market } \\
\text { is about 10\%. }\end{array}$ \\
\hline Company's customers & Urban households \\
\hline $\begin{array}{l}\text { Company's marketing } \\
\text { approaches }\end{array}$ & Direct sales \\
\hline Annual sales revenues & $\$ 3$ million in solar water heaters alone (other income unknown) \\
\hline $\begin{array}{l}\text { Estimate of market } \\
\text { potential for products } \\
\text { in country and abroad }\end{array}$ & $\bullet \quad$ Solar water heaters: Over 700,000 m ${ }^{2}$ (\$87.5-\$210 million U.S.) \\
\hline $\begin{array}{l}\text { Business goals and } \\
\text { objectives }\end{array}$ & $\bullet \quad$ Expand their research towards commercialization \\
\hline $\begin{array}{l}\text { Interest in working } \\
\text { with U.S. partners }\end{array}$ & Willing to work with U.S. partners. \\
\hline $\begin{array}{l}\text { Specific products and } \\
\text { services expected from } \\
\text { partnership }\end{array}$ & $\bullet \quad \begin{array}{l}\text { Assistance with research and investment } \\
\text { Up-to-date production lines for products }\end{array}$ \\
\hline
\end{tabular}




\begin{tabular}{|c|c|}
\hline & Guangdong Feng Shou Sugar Development Company \\
\hline Address & Tel.: 86759/ 8944037; fax: 86759/8944149 \\
\hline $\begin{array}{l}\text { Type of } \\
\text { company }\end{array}$ & $\begin{array}{l}\text { State owned by Central \& local Agriculture Cultivation Bureau of Inner } \\
\text { Mongolia }\end{array}$ \\
\hline Main contact & Huang Guo Tao, President \\
\hline Type of products & Sugar, canned pineapple, particleboard, fertilizer, alcohol, and electricity \\
\hline Price of products & Electricity: $\$ 0.05 / \mathrm{kWh}$ U.S. \\
\hline Market share & $\mathrm{N} / \mathrm{A}$ \\
\hline Company's customers & International \\
\hline $\begin{array}{l}\text { Company's customers } \\
\text { and marketing } \\
\text { approaches }\end{array}$ & $\begin{array}{l}\text { Wholesalers distribute products worldwide (mainly to U.S., Canada, and } \\
\text { Europe via Hong Kong) }\end{array}$ \\
\hline Annual sales revenues & $\$ 54.7$ million U.S. \\
\hline $\begin{array}{l}\text { Estimate of market } \\
\text { potential for products } \\
\text { in country and abroad }\end{array}$ & - N/A \\
\hline $\begin{array}{l}\text { Business goals and } \\
\text { objectives }\end{array}$ & $\begin{array}{l}\text { - Increase scale of sugar production to } 1 \text { million tons/year } \\
\text { - Improve local living standards and ecology } \\
\text { - Upgrade generators }\end{array}$ \\
\hline $\begin{array}{l}\text { Interest in working } \\
\text { with U.S. partners } \\
\end{array}$ & Willing to work with U.S. partners. \\
\hline $\begin{array}{l}\text { Specific products and } \\
\text { services expected from } \\
\text { partnership }\end{array}$ & $\begin{array}{l}\text { - Foreign partners provide capital to improve production capabilities } \\
\text { - Management know-how }\end{array}$ \\
\hline
\end{tabular}




\begin{tabular}{|c|c|}
\hline & Suixi Beipo Sugar Mill \\
\hline Address & Tel.: 86759/7171403; fax: 86759/7171348 \\
\hline Type of company & State owned \\
\hline Main contact & Liu Chang Quan, President \\
\hline Type of products & Alcohol, sugar, particleboard, and electricity \\
\hline Price of products & Electricity: $\$ 0.06 / \mathrm{kWh}$ U.S. \\
\hline Market share & $\begin{array}{l}\text { The company holds a virtual monopoly on wind farm development in } \\
\text { Guangdong. }\end{array}$ \\
\hline Company's customers & Provincial utility buys electricity. Other products sold internationally. \\
\hline $\begin{array}{l}\text { Company's marketing } \\
\text { approaches }\end{array}$ & $\mathrm{N} / \mathrm{A}$ \\
\hline Annual sales revenues & $\mathrm{N} / \mathrm{A}$ \\
\hline \begin{tabular}{|l|} 
Estimate of market \\
potential for products \\
in \\
country and abroad
\end{tabular} & $\mathrm{N} / \mathrm{A}$ \\
\hline $\begin{array}{l}\text { Business goals and } \\
\text { objectives }\end{array}$ & $\begin{array}{l}\text { - Increase particleboard component of the business } \\
\text { - Expand commercialization of biogas }\end{array}$ \\
\hline $\begin{array}{l}\text { Interest in working with } \\
\text { U.S. partners }\end{array}$ & $\begin{array}{l}\text { Willing to work with U.S. partners; however, they are uninterested in } \\
\text { expanding their energy production. They would rather utilize extra bagasse to } \\
\text { grow their particleboard business. }\end{array}$ \\
\hline $\begin{array}{l}\text { Specific products and } \\
\text { services expected from } \\
\text { partnership }\end{array}$ & 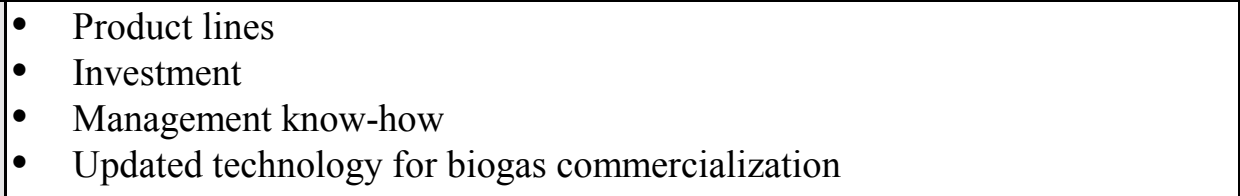 \\
\hline
\end{tabular}




\begin{tabular}{|l|l|}
\hline & \multicolumn{1}{|c|}{ Jiujiang Electric Power Bureau } \\
\hline Address & Tel.: (86792) 8464907 \\
\hline Type of company & State owned \\
\hline Main contact & Zhao Bao Heng, Deputy Director \\
\hline Type of products & Electricity and power plant development \\
\hline Price of products & N/A \\
\hline Market share & $\begin{array}{l}\text { The company holds a virtual monopoly on all power plant development in } \\
\text { Xingzi County. }\end{array}$ \\
\hline Company's customers & Provincial utility buys electricity. \\
\hline $\begin{array}{l}\text { Company's marketing } \\
\text { approaches }\end{array}$ & N/A \\
\hline Annual sales revenues & N/A \\
\hline $\begin{array}{l}\text { Estimate of market } \\
\text { potential for products } \\
\text { in } \\
\text { country and abroad }\end{array}$ & N/A \\
\hline $\begin{array}{l}\text { Business goals and } \\
\text { objectives }\end{array}$ & $\begin{array}{l}\text { To become more self-sufficient with the production of energy while } \\
\text { simultaneously providing the lowest-cost power to its customers }\end{array}$ \\
\hline $\begin{array}{l}\text { Interest in working with } \\
\text { U.S. partners }\end{array}$ & $\begin{array}{l}\text { If the U.S. partner wishes to invest money, the power bureau would welcome } \\
\text { it. However, they are not too keen on becoming partners with foreign } \\
\text { companies due to a lack of understanding of what is involved with joint } \\
\text { ventures. }\end{array}$ \\
\hline $\begin{array}{l}\text { Specific products and } \\
\text { services expected from } \\
\text { partnership }\end{array}$ & \begin{tabular}{l} 
Investment \\
\hline
\end{tabular} \\
\hline
\end{tabular}




\begin{tabular}{|l|l|}
\hline & \multicolumn{1}{|c|}{ Jilin Province Energy Resources Institute } \\
\hline Address & $\begin{array}{l}\text { No. 27 Nanhu Rd., 130012 Changchun, Jilin, P.R. China } \\
\text { Tel.: (86431) 5953461-7 (x209); fax: (86431) 5969007 }\end{array}$ \\
\hline Type of company & State owned \\
\hline Main contact & Gu Huiqing, Director \\
\hline Type of products & Various biogas products, developer of biogas projects \\
\hline Price of products & N/A \\
\hline Market share & N/A \\
\hline Company's customers & $\begin{array}{l}\text { Company is in the nascent stage of marketing efforts. The customers will be } \\
\text { individual urban households. }\end{array}$ \\
\hline $\begin{array}{l}\text { Company's marketing } \\
\text { approaches }\end{array}$ & N/A \\
\hline Annual sales revenues & N/A \\
\hline $\begin{array}{l}\text { Estimate of market } \\
\text { potential for products } \\
\text { in } \\
\text { country and abroad }\end{array}$ & Have yet to analyze the economics of the system \\
\hline $\begin{array}{l}\text { Business goals and } \\
\text { objectives }\end{array}$ & $\begin{array}{l}\text { To develop centralized gas system on a large scale and commercialize the } \\
\text { business }\end{array}$ \\
\hline $\begin{array}{l}\text { Interest in working with } \\
\text { U.S. partners }\end{array}$ & $\begin{array}{l}\text { Willing to work with U.S. partners. However, they are uninterested in } \\
\text { expanding their energy production. They would rather utilize extra bagasse to } \\
\text { grow their particle-board business. } \\
\text { Specific products and } \\
\text { services expected from } \\
\text { partnership }\end{array}$ \\
$\begin{array}{l}\text { Product lines } \\
\text { Investment } \\
\text { Management know-how } \\
\text { Updated technology for biogas commercialization }\end{array}$ \\
\hline
\end{tabular}




\begin{tabular}{|c|c|}
\hline & Jilin Wind Power Stockholding Company \\
\hline Address & $\begin{array}{l}\text { No. 20-1 Fengshun St., 130021 Changchun, Jilin, P.R. China } \\
\text { Tel.: (86431) 5665277; fax: (86431) 5665444 }\end{array}$ \\
\hline Type of company & State owned \\
\hline Main contact & Cong Jingquan, Vice-General Manager \\
\hline Type of products & Electricity and wind farm and hydropower development \\
\hline Price of products & Electricity: \$0.125/kWh U.S. for wind energy \\
\hline Market share & Currently, the company is the only developer in Jilin. \\
\hline $\begin{array}{l}\text { Company's } \\
\text { customers }\end{array}$ & Provincial utility buys electricity. \\
\hline $\begin{array}{l}\text { Company's } \\
\text { marketing } \\
\text { approaches }\end{array}$ & $\mathrm{N} / \mathrm{A}$ \\
\hline $\begin{array}{l}\text { Annual sales } \\
\text { revenues }\end{array}$ & $\mathrm{N} / \mathrm{A}$ \\
\hline $\begin{array}{l}\text { Estimate of market } \\
\text { potential for } \\
\text { products in country } \\
\text { and abroad }\end{array}$ & $100,000,000 /$ year for electricity for wind energy alone. \\
\hline $\begin{array}{l}\text { Business goals and } \\
\text { objectives }\end{array}$ & $\begin{array}{l}\text { - To first develop the Tongfa area and eventually develop Jilin's entire wind } \\
\text { capability } \\
\text { - To develop Antau hydro projects }\end{array}$ \\
\hline $\begin{array}{l}\text { Interest in working } \\
\text { with U.S. partners }\end{array}$ & Willing to work with U.S. partners \\
\hline $\begin{array}{l}\text { Specific products } \\
\text { and services } \\
\text { expected from } \\
\text { partnership }\end{array}$ & $\begin{array}{l}\text { - } \quad \text { Investment } \\
\text { - } \quad \text { Modern equipment and technology }\end{array}$ \\
\hline
\end{tabular}




\begin{tabular}{|c|c|}
\hline & Global Solar Energy Equipment Company \\
\hline Address & Tel.: (86871) 83112161 \\
\hline Type of company & State owned \\
\hline Main contact & Zhu Xiangguan, General Manager \\
\hline Type of products & Solar/thermal collectors, solar water heaters \\
\hline Price of products & $\$ 218-\$ 315$ U.S. \\
\hline Market share & $\begin{array}{l}-30 \% \text { of Yunnan } \\
\text { - } \quad 10 \% \text { of China } \\
\end{array}$ \\
\hline Company's customers & Individual households and middlemen \\
\hline $\begin{array}{l}\text { Company's marketing } \\
\text { approaches }\end{array}$ & Direct sales \\
\hline Annual sales revenues & $\sim \$ 5$ million U.S. \\
\hline $\begin{array}{l}\text { Estimate of market } \\
\text { potential for products } \\
\text { in } \\
\text { country and abroad }\end{array}$ & - Solar water heaters: Over 700,000 $\mathrm{m}^{2}$ (\$87.5-\$210 million U.S.) in China \\
\hline $\begin{array}{l}\text { Business goals and } \\
\text { objectives }\end{array}$ & $\begin{array}{l}\text { - To make the best use of solar energy for the benefit of China } \\
\text { - Maximize their production capability and sell } 100 \mathrm{~m}^{2} \text { of solar collectors } \\
\text { per year by } 1999 \\
\text { - Expand production lines to include PV products }\end{array}$ \\
\hline $\begin{array}{l}\text { Interest in working with } \\
\text { U.S. partners }\end{array}$ & Willing to work with U.S. partners. \\
\hline $\begin{array}{l}\text { Specific products and } \\
\text { services expected from } \\
\text { partnership }\end{array}$ & $\begin{array}{ll}- & \text { Production lines } \\
- & \text { Investment } \\
\text { - } & \text { Management know-how } \\
\end{array}$ \\
\hline
\end{tabular}




\begin{tabular}{|c|c|}
\hline & Kunming Xinying Solar Energy Facility Plant \\
\hline Address & $\begin{array}{l}\text { 8th Group, North Part, Xinying District, } 620225 \text { Kunming, P.R.China } \\
\text { Tel.: (86871) 3326168; fax: (86871) 3342828 }\end{array}$ \\
\hline Type of company & Privately owned \\
\hline Main contact & Zhu, President; Chen Shen, Assistant Factory Director \\
\hline Type of products & Solar-thermal collectors, solar water heaters \\
\hline Price of products & $\begin{array}{l}\text { - } 4-\mathrm{m}^{2} \text { solar water heater: } \$ 292 \text { U.S. } \\
\text { - } 6-\mathrm{m}^{2} \text { solar water heater: } \$ 438 \text { U.S. } \\
\text { - } 12-\mathrm{m}^{2} \text { solar water heater: } \$ 876 \text { U.S. } \\
\end{array}$ \\
\hline Market share & $10 \%-20 \%$ of Yunnan \\
\hline Company's customers & Housing developers \\
\hline $\begin{array}{l}\text { Company's marketing } \\
\text { approaches }\end{array}$ & Institutional marketing approach \\
\hline Annual sales revenues & Approximately \$1.5 million U.S. for solar water heaters alone \\
\hline $\begin{array}{l}\text { Estimate of market } \\
\text { potential for products } \\
\text { in } \\
\text { country and abroad }\end{array}$ & Solar water heaters: Over $700,000 \mathrm{~m}^{2}(\$ 87.5-\$ 210$ million U.S.) in China \\
\hline $\begin{array}{l}\text { Business goals and } \\
\text { objectives }\end{array}$ & $\begin{array}{l}\text { - Commercialize new technological innovation for its solar/thermal collector } \\
\text { - Expand its product lines to include PV }\end{array}$ \\
\hline $\begin{array}{l}\text { Interest in working with } \\
\text { U.S. partners }\end{array}$ & Willing to work with U.S. partners \\
\hline $\begin{array}{l}\text { Specific products and } \\
\text { services expected from } \\
\text { partnership }\end{array}$ & $\begin{array}{ll}- & \text { Production lines } \\
\text { - } & \text { Investment } \\
\text { - } & \text { Upanagement know-how } \\
\end{array}$ \\
\hline
\end{tabular}




\begin{tabular}{|l|l|}
\hline & Yunnan Provincial Power Bureau \\
\hline Address & $\begin{array}{l}\text { Dongfengdong Rd. No. 57, 650041 Kunming, P.R. China } \\
\text { Tel.: (86871) 3161899; fax: (86871) 3165698 }\end{array}$ \\
\hline Type of company & State owned \\
\hline Main contact & Xie Kunsheng, Deputy Director/Deputy General Manager \\
\hline Type of products & Electricity \\
\hline Price of products & N/A \\
\hline Market share & Monopoly on all power in Yunnan \\
\hline Company's customers & N/A \\
\hline $\begin{array}{l}\text { Company's marketing } \\
\text { approaches }\end{array}$ & N/A \\
\hline Annual sales revenues & N/A \\
\hline $\begin{array}{l}\text { Estimate of market } \\
\text { potential for products } \\
\text { in } \\
\text { country and abroad }\end{array}$ & $\bullet \quad$ Approximately 6,000 MW of hydropower \\
\hline $\begin{array}{l}\text { Business goals and } \\
\text { objectives }\end{array}$ & $\begin{array}{l}\text { To develop hydro resources to allow Yunnan to be fully self-sufficient in energy } \\
\text { production }\end{array}$ \\
\hline $\begin{array}{l}\text { Interest in working with } \\
\text { U.S. partners }\end{array}$ & Willing to work with U.S. partners \\
\hline $\begin{array}{l}\text { Specific products and } \\
\text { services expected from } \\
\text { partnership }\end{array}$ & $\bullet$ Investment \\
\hline
\end{tabular}




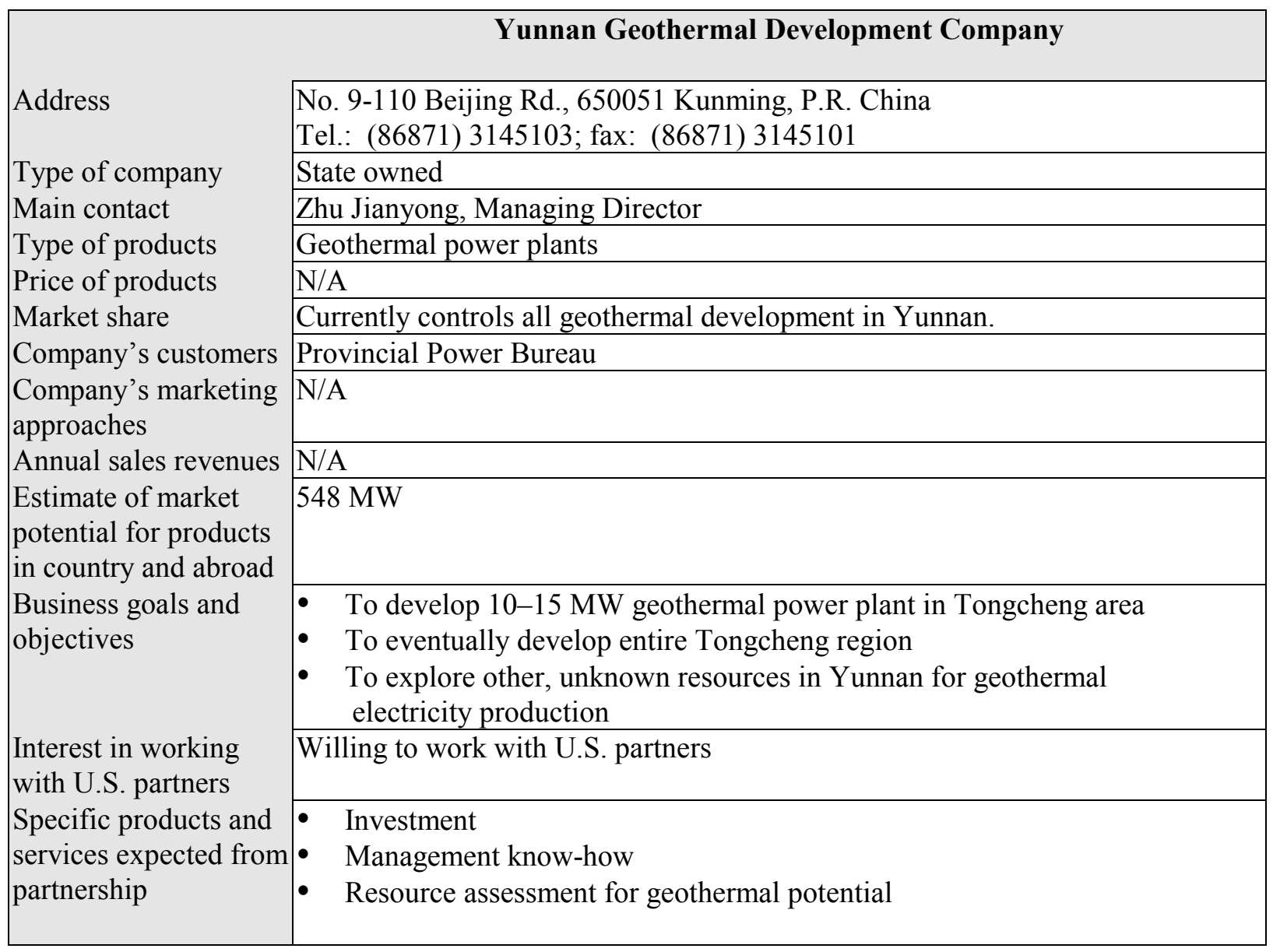




\begin{tabular}{|c|c|}
\hline & Yunnan Semiconductor Device Factory \\
\hline Address & $\begin{array}{l}\text { 24 Jianshe Rd., } 650033 \text { Kunming, P.R. China } \\
\text { Tel.: (86871) 5321431; fax: (86871) 5337279 }\end{array}$ \\
\hline Type of company & State owned \\
\hline Main contact & Zhu Huimin, Executive Vice-Director \\
\hline Type of products & PV cells \\
\hline Price of products & $\begin{array}{ll}\text { - } & \text { 8-18-W Module: } \$ 43.76-\$ 98.46 \text { U.S. } \\
\text { - } & 35-38-W \text { Module: } \$ 191.45-\$ 207.86 \text { U.S. }\end{array}$ \\
\hline Market share & - $40 \%$ of China \\
\hline Company's customers & $\begin{array}{ll}\text { - } & \text { Individual households } \\
\text { - } & \text { Middlemen } \\
\text { - } & \text { Telecommunications industry } \\
\end{array}$ \\
\hline $\begin{array}{l}\text { Company's marketing } \\
\text { approaches }\end{array}$ & Direct sales \\
\hline Annual sales revenues & Approximately \$2.5 million U.S. for solar modules \\
\hline $\begin{array}{l}\text { Estimate of market } \\
\text { potential for products } \\
\text { in } \\
\text { country and abroad }\end{array}$ & N/A \\
\hline $\begin{array}{l}\text { Business goals and } \\
\text { objectives }\end{array}$ & $\begin{array}{l}\text { - } \\
\text { - } \\
\text { - } \\
\text { - Increarease technological capability and expand into international market } \\
\text { Develop silicon-manufacturing plant }\end{array}$ \\
\hline \begin{tabular}{|l|} 
Interest in working with \\
U.S. partners
\end{tabular} & Willing to work with U.S. partners \\
\hline $\begin{array}{l}\text { Specific products and } \\
\text { services expected from } \\
\text { partnership }\end{array}$ & $\begin{array}{ll}\text { - } & \text { Production lines } \\
\text { - } & \text { Investment } \\
\text { - } & \text { Management know-how } \\
\text { - } & \text { Reliable PV technology } \\
\end{array}$ \\
\hline
\end{tabular}




\section{Appendix B}

Monthly Wind Measurements in Specific Locations in Guangdong Province

Nan 'Ao Guohao Mountain Monthly Wind Speeds at 10-m Heights (Jan-Dec 1988)

\begin{tabular}{|l|c|c|c|c|c|c|c|c|c|c|c|c|}
\hline \multicolumn{1}{|c|}{ Item } & Jan & Feb & $\begin{array}{c}\text { Ma } \\
\text { r }\end{array}$ & Apr & May & Jun & Jul & Aug & Sep & Oct & Nov & Dec \\
\hline \hline $\mathrm{m} / \mathrm{s}$ & 9.6 & 8.8 & 8.6 & 7.6 & 7.1 & 7.8 & 6.8 & 6.1 & 8.3 & 7.7 & 11.9 & 11.0 \\
\hline $\begin{array}{l}3-20 \mathrm{~m} / \mathrm{s} \\
\text { (Hours) }\end{array}$ & 681 & 606 & 557 & 481 & 568 & 608 & 521 & 590 & 587 & 662 & 582 & 668 \\
\hline $\begin{array}{l}3-20 \mathrm{~m} / \mathrm{s} \\
\left(\mathrm{W} / \mathrm{m}^{2}\right)\end{array}$ & 923 & 910 & 715 & 585 & 602 & 624 & 336 & 262 & 582 & 398 & 1081 & 1115 \\
\hline
\end{tabular}

Source: Guangdong Provincial Power Bureau

Huilai Lighthouse Monthly Wind Speeds at 10-m Heights (Oct 1995-Sep 1996)

\begin{tabular}{|l|c|c|c|c|c|c|c|c|c|c|c|c|}
\hline \multicolumn{1}{|c|}{ Item } & $\begin{array}{c}\text { 1st } \\
\text { mo. }\end{array}$ & $\begin{array}{c}\text { 2nd } \\
\text { mo. }\end{array}$ & $\begin{array}{c}\text { 3rd } \\
\text { mo. }\end{array}$ & $\begin{array}{c}\text { 4th } \\
\text { mo. }\end{array}$ & $\begin{array}{c}\text { 5th } \\
\text { mo. }\end{array}$ & $\begin{array}{c}\text { 6th } \\
\text { mo. }\end{array}$ & $\begin{array}{c}\text { 7th } \\
\text { mo. }\end{array}$ & $\begin{array}{c}\text { 8th } \\
\text { mo. }\end{array}$ & $\begin{array}{c}\text { 9th } \\
\text { mo. }\end{array}$ & $\begin{array}{c}\mathbf{1 0 t} \\
\mathbf{h} \\
\text { mo. }\end{array}$ & $\begin{array}{c}\mathbf{1 1 t} \\
\mathbf{h} \\
\text { mo. }\end{array}$ & $\begin{array}{c}\mathbf{1 2 t} \\
\mathbf{h} \\
\text { mo. }\end{array}$ \\
\hline \hline $\mathrm{m} / \mathrm{s}$ & 7.1 & 7.3 & 6.7 & 7.4 & 5.5 & 3.6 & 3.9 & 3.7 & 7.3 & 8.6 & 7.4 & 7.8 \\
\hline $\begin{array}{l}3-20 \mathrm{~m} / \mathrm{s} \\
(\mathrm{Hours})\end{array}$ & 720 & 659 & 670 & 647 & 621 & 479 & 502 & 465 & 410 & 742 & 691 & 731 \\
\hline $\begin{array}{l}3-20 \mathrm{~m} / \mathrm{s} \\
\left(\mathrm{W} / \mathrm{m}^{2}\right)\end{array}$ & 306 & 376 & 312 & 489 & 191 & 58 & 90 & 78 & 322 & 460 & 424 & 308 \\
\hline
\end{tabular}

Source: Guangdong Provincial Power Bureau

Huilai Bay Monthly Wind Speeds at 10-m Heights (Oct 1995-Sep 1996)

\begin{tabular}{|l|c|c|c|c|c|c|c|c|c|c|c|c|}
\hline \multicolumn{1}{|c|}{ Item } & $\begin{array}{c}\text { 1st } \\
\text { mo. }\end{array}$ & $\begin{array}{c}\text { 2nd } \\
\text { mo. }\end{array}$ & $\begin{array}{c}\text { 3rd } \\
\text { mo. }\end{array}$ & $\begin{array}{c}\text { 4th } \\
\text { mo. }\end{array}$ & $\begin{array}{c}\text { 5th } \\
\text { mo. }\end{array}$ & $\begin{array}{c}\text { 6th } \\
\text { mo. }\end{array}$ & $\begin{array}{c}\text { 7th } \\
\text { mo. }\end{array}$ & $\begin{array}{c}\text { 8th } \\
\text { mo. }\end{array}$ & $\begin{array}{c}\text { 9th } \\
\text { mo. }\end{array}$ & $\begin{array}{c}\mathbf{1 0 t} \\
\text { h } \\
\text { mo. }\end{array}$ & $\begin{array}{c}\text { 11t } \\
\text { ho. }\end{array}$ & $\begin{array}{c}\mathbf{1 2 t} \\
\text { mo. } \\
\text { mo. }\end{array}$ \\
\hline \hline $\begin{array}{l}\mathrm{m} / \mathrm{s} \\
\begin{array}{l}3-20 \mathrm{~m} / \mathrm{s} \\
(\text { Hours })\end{array}\end{array}$ & 6.6 & 7.0 & 6.1 & 6.7 & 5.1 & 3.5 & 3.5 & 3.7 & 7.3 & 8.4 & 6.6 & 7.4 \\
\hline $\begin{array}{l}3-20 \mathrm{~m} / \mathrm{s} \\
(\mathrm{W} / \mathrm{m} 2)\end{array}$ & 235 & 299 & 235 & 367 & 149 & 57 & 57 & 88 & 291 & 392 & 232 & 321 \\
\hline
\end{tabular}

Source: Guangdong Provincial Power Bureau

Huilai Bay Monthly Wind Speeds at 25-m Heights (Oct 1995-Sep 1996)

\begin{tabular}{|l|c|c|c|c|c|c|c|c|c|c|c|c|}
\hline \multicolumn{1}{|c|}{ Item } & $\begin{array}{c}\text { 1st } \\
\text { mo. }\end{array}$ & $\begin{array}{c}\text { 2nd } \\
\text { mo. }\end{array}$ & $\begin{array}{c}\text { 3rd } \\
\text { mo. }\end{array}$ & $\begin{array}{c}\text { 4th } \\
\text { mo. }\end{array}$ & $\begin{array}{c}\text { 5th } \\
\text { mo. }\end{array}$ & $\begin{array}{c}\text { 6th } \\
\text { mo. }\end{array}$ & $\begin{array}{c}\text { 7th } \\
\text { mo. }\end{array}$ & $\begin{array}{c}\text { 8th } \\
\text { mo. }\end{array}$ & $\begin{array}{c}\text { 9th } \\
\text { mo. }\end{array}$ & $\begin{array}{c}\text { 10t } \\
\text { h } \\
\text { mo. }\end{array}$ & $\begin{array}{c}\text { 11t } \\
\text { h } \\
\text { mo. }\end{array}$ & $\begin{array}{c}\text { 12t } \\
\text { h } \\
\text { mo. }\end{array}$ \\
\hline \hline \begin{tabular}{l}
$\mathrm{m} / \mathrm{s}$ \\
\hline$-20 \mathrm{~m} / \mathrm{s}$ \\
$($ Hours $)$
\end{tabular} & 7.6 & 8.3 & 8.0 & 8.1 & 6.3 & 4.7 & 4.4 & 4.8 & 8.0 & 9.4 & 8.4 & 8.9 \\
\hline $\begin{array}{l}3-20 \mathrm{~m} / \mathrm{s} \\
\left(\mathrm{W} / \mathrm{m}^{2}\right)\end{array}$ & 661 & 741 & 656 & 688 & 577 & 600 & 570 & 703 & 743 & 705 & 738 \\
\hline
\end{tabular}

Source: Guangdong Provincial Power Bureau 
Zhelang Monthly Wind Speeds at 10-m Heights (May 1989-April 1990)

\begin{tabular}{|c|c|c|c|c|c|c|c|c|c|c|c|c|}
\hline Item & $\begin{array}{c}\text { 1st } \\
\text { mo. }\end{array}$ & $\begin{array}{c}\text { 2nd } \\
\text { mo. }\end{array}$ & $\begin{array}{c}\text { 3rd } \\
\text { mo. }\end{array}$ & $\begin{array}{c}\text { 4th } \\
\text { mo. }\end{array}$ & $\begin{array}{c}\text { 5th } \\
\text { mo. }\end{array}$ & $\begin{array}{c}\text { 6th } \\
\text { mo. }\end{array}$ & $\begin{array}{c}\text { 7th } \\
\text { mo. }\end{array}$ & $\begin{array}{c}\text { 8th } \\
\text { mo. }\end{array}$ & $\begin{array}{c}\text { 9th } \\
\text { mo. }\end{array}$ & $\begin{array}{c}\text { 10t } \\
\text { h } \\
\text { mo. }\end{array}$ & $\begin{array}{c}\mathbf{1 1 t} \\
\text { h } \\
\text { mo. }\end{array}$ & $\begin{array}{c}\text { 12t } \\
\text { h } \\
\text { mo. }\end{array}$ \\
\hline $\mathrm{M} / \mathrm{s}$ & 7.7 & 6.9 & 6.7 & 6.9 & 6.3 & 6.6 & 5.8 & 4.5 & 5.1 & 8.7 & 7.6 & 6.7 \\
\hline $\begin{array}{c}3-20 \mathrm{~m} / \mathrm{s} \\
(\mathrm{Hours})\end{array}$ & 714 & 601 & 666 & 660 & 625 & 695 & 621 & 614 & 587 & 693 & 700 & 691 \\
\hline $\begin{array}{c}3-20 \mathrm{~m} / \mathrm{s} \\
\left(\mathrm{W} / \mathrm{m}^{2}\right)\end{array}$ & 444 & 435 & 410 & 374 & 411 & 244 & 318 & 119 & 222 & 704 & 395 & 335 \\
\hline
\end{tabular}

Source: Guangdong Provincial Power Bureau

Zhuhai High Railing Monthly Wind Speeds at 10-m Heights (Oct 1995-Sep 1996)

\begin{tabular}{|c|c|c|c|c|c|c|c|c|c|c|c|c|}
\hline Item & $\begin{array}{c}\text { 1st } \\
\text { mo. }\end{array}$ & $\begin{array}{c}\text { 2nd } \\
\text { mo. }\end{array}$ & $\begin{array}{c}\text { 3rd } \\
\text { mo. }\end{array}$ & $\begin{array}{c}\text { 4th } \\
\text { mo. }\end{array}$ & $\begin{array}{c}\text { 5th } \\
\text { mo. }\end{array}$ & $\begin{array}{c}\text { 6th } \\
\text { mo. }\end{array}$ & $\begin{array}{c}\text { 7th } \\
\text { mo. }\end{array}$ & $\begin{array}{c}\text { 8th } \\
\text { mo. }\end{array}$ & $\begin{array}{c}\text { 9th } \\
\text { mo. }\end{array}$ & $\begin{array}{c}\mathbf{1 0 t} \\
\mathbf{h} \\
\text { mo. }\end{array}$ & $\begin{array}{c}\text { 11t } \\
\text { h } \\
\text { mo. }\end{array}$ & $\begin{array}{c}\mathbf{1 2 t} \\
\text { h } \\
\text { mo. }\end{array}$ \\
\hline $\mathrm{M} / \mathrm{s}$ & 5.9 & 7.8 & 5.9 & 5.7 & 5.2 & 6.5 & 6.0 & 5.2 & 5.0 & 6.5 & 6.4 & 6.7 \\
\hline $\begin{array}{c}3-20 \mathrm{~m} / \mathrm{s} \\
(\mathrm{Hours})\end{array}$ & 648 & 647 & 645 & 655 & 656 & 683 & 686 & 641 & 600 & 690 & 647 & 672 \\
\hline $\begin{array}{c}3-20 \mathrm{~m} / \mathrm{s} \\
\left(\mathrm{W} / \mathrm{m}^{2}\right)\end{array}$ & 275 & 594 & 247 & 218 & 149 & 246 & 203 & 151 & 152 & 314 & 380 & 350 \\
\hline
\end{tabular}

Source: Guangdong Provincial Power Bureau

Yangjiang Coastal Island Mountaintop Monthly Wind Speeds at 10-m Heights (Oct 1995-Sep 1996)

\begin{tabular}{|c|c|c|c|c|c|c|c|c|c|c|c|c|}
\hline Item & $\begin{array}{c}\text { 1st } \\
\text { mo. }\end{array}$ & $\begin{array}{c}\text { 2nd } \\
\text { mo. }\end{array}$ & $\begin{array}{c}\text { 3rd } \\
\text { mo. }\end{array}$ & $\begin{array}{c}\text { 4th } \\
\text { mo. }\end{array}$ & $\begin{array}{c}\text { 5th } \\
\text { mo. }\end{array}$ & $\begin{array}{c}\text { 6th } \\
\text { mo. }\end{array}$ & $\begin{array}{c}\text { 7th } \\
\text { mo. }\end{array}$ & $\begin{array}{c}\text { 8th } \\
\text { mo. }\end{array}$ & $\begin{array}{c}\text { 9th } \\
\text { mo. }\end{array}$ & $\begin{array}{c}\text { 10t } \\
\text { h } \\
\text { mo. }\end{array}$ & $\begin{array}{c}\text { 11t } \\
\text { h } \\
\text { mo. }\end{array}$ & $\begin{array}{c}\text { 12t } \\
\text { h } \\
\text { mo. }\end{array}$ \\
\hline $\mathrm{M} / \mathrm{s}$ & 7.1 & 7.6 & 6.4 & 6.0 & 5.3 & 5.7 & 6.2 & 5.4 & 6.4 & 7.4 & 6.9 & 5.5 \\
\hline $\begin{array}{c}3-20 \mathrm{~m} / \mathrm{s} \\
(\mathrm{Hours})\end{array}$ & 695 & 651 & 687 & 683 & 650 & 653 & 680 & 653 & 631 & 480 & 174 & 648 \\
\hline $\begin{array}{c}3-20 \mathrm{~m} / \mathrm{s} \\
\left(\mathrm{W} / \mathrm{m}^{2}\right)\end{array}$ & 357 & 407 & 275 & 181 & 153 & 189 & 296 & 225 & 532 & 297 & 281 & 186 \\
\hline
\end{tabular}

Source: Guangdong Provincial Power Bureau

Island Near Zhanjiang Monthly Wind Speeds at 10-m Heights (Oct 1995-Sep 1996)

\begin{tabular}{|c|c|c|c|c|c|c|c|c|c|c|c|c|}
\hline Item & $\begin{array}{c}\text { 1st } \\
\text { mo. }\end{array}$ & $\begin{array}{c}\text { 2nd } \\
\text { mo. }\end{array}$ & $\begin{array}{c}\text { 3rd } \\
\text { mo. }\end{array}$ & $\begin{array}{c}\text { 4th } \\
\text { mo. }\end{array}$ & $\begin{array}{c}\text { 5th } \\
\text { mo. }\end{array}$ & $\begin{array}{c}\text { 6th } \\
\text { mo. }\end{array}$ & $\begin{array}{c}\text { 7th } \\
\text { mo. }\end{array}$ & $\begin{array}{c}\text { 8th } \\
\text { mo. }\end{array}$ & $\begin{array}{c}\text { 9th } \\
\text { mo. }\end{array}$ & $\begin{array}{c}\mathbf{1 0 t} \\
\text { h } \\
\text { mo. }\end{array}$ & $\begin{array}{c}\mathbf{1 1 t} \\
\text { h } \\
\text { mo. }\end{array}$ & $\begin{array}{c}\mathbf{1 2 t} \\
\text { h } \\
\text { mo. }\end{array}$ \\
\hline $\mathrm{M} / \mathrm{s}$ & 5.8 & 6.4 & 5.0 & 6.7 & 5.8 & 6.2 & 6.6 & 5.4 & 8.1 & 6.9 & 6.2 & 7.2 \\
\hline $\begin{array}{c}3-20 \mathrm{~m} / \mathrm{s} \\
(\mathrm{Hours})\end{array}$ & 690 & 622 & 563 & 658 & 605 & 661 & 674 & 636 & 635 & 689 & 590 & 717 \\
\hline $\begin{array}{c}3-20 \mathrm{~m} / \mathrm{s} \\
\left(\mathrm{W} / \mathrm{m}^{2}\right)\end{array}$ & 185 & 273 & 198 & 319 & 254 & 232 & 397 & 240 & 569 & 317 & 290 & 324 \\
\hline
\end{tabular}

Source: Guangdong Provincial Power Bureau 


\section{Appendix C}

\section{Project Approval Procedure for Small Projects in China}

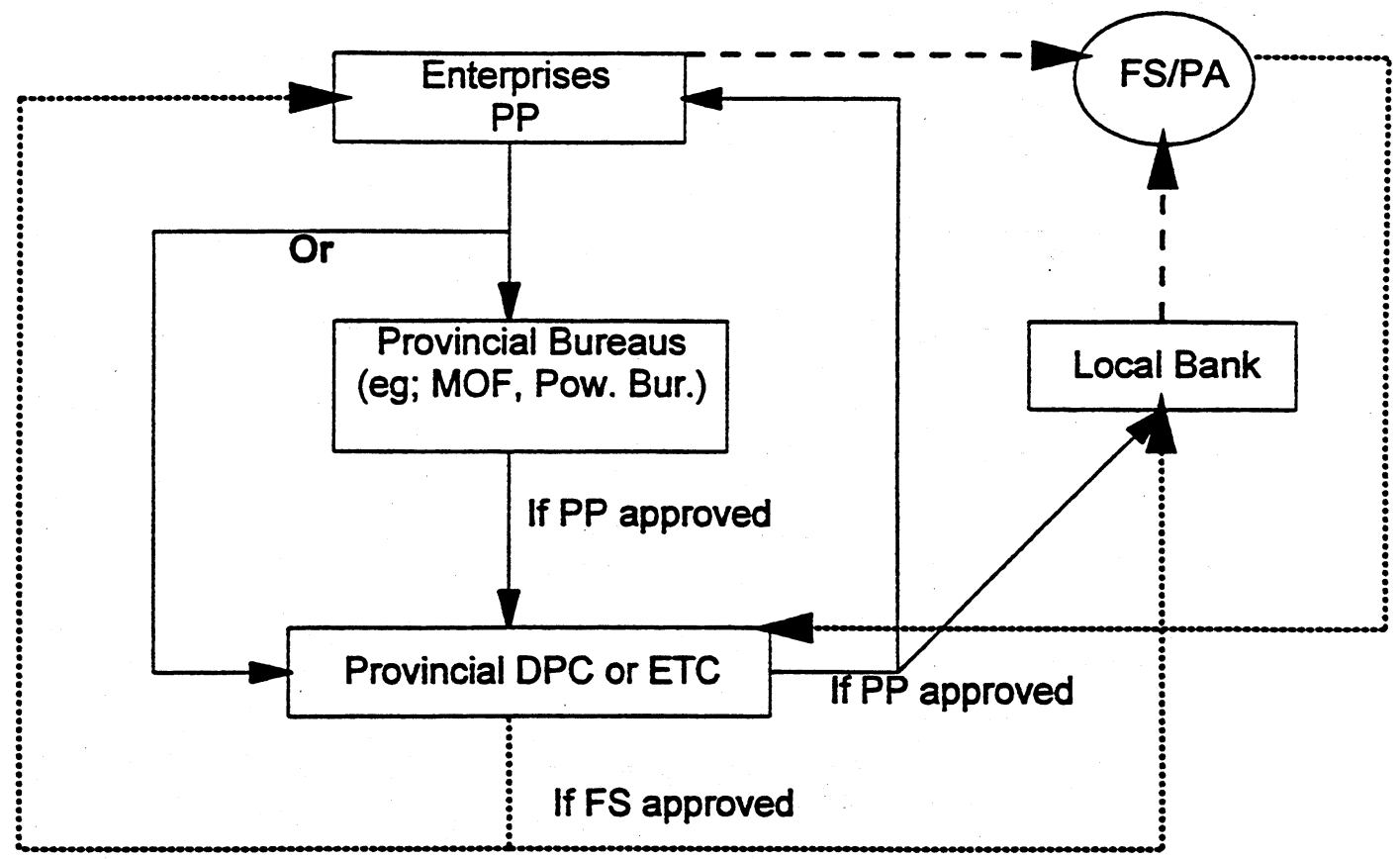

Key:

\section{Project Proposal (PP)}

\section{Feasibility Study (FS) / Project Appraisal (PA)}

Indicates Local Bank \& Enterprise Preparing FS/PA Together

This procedure is meant for projects with total budgets valued less than $\$ 30$ million U.S. for a State Development Planning Commission (SDPC) project (construction project) or $\$ 50$ million U.S. for a State Economic and Trade Commission (SETC) project (renovation project). This project can be approved by provincial authorities, but the total need for foreign capital must be reported to the central SDPC in Beijing.

The enterprise first prepares its proposal and takes it to either the appropriate power bureau and the provincial branch of the DPC or ETC. If the proposal is approved, both the local bank and the enterprise will prepare a feasibility study, which needs the approval of the provincial DPC or ETC. After the feasibility study is approved, the local bank and the enterprise will prepare a project appraisal that goes through the same approval procedure as the feasibility study. Once the project appraisal is approved, then the project is ready to be developed. 


\section{Project Approval Procedure for Large Projects in China}
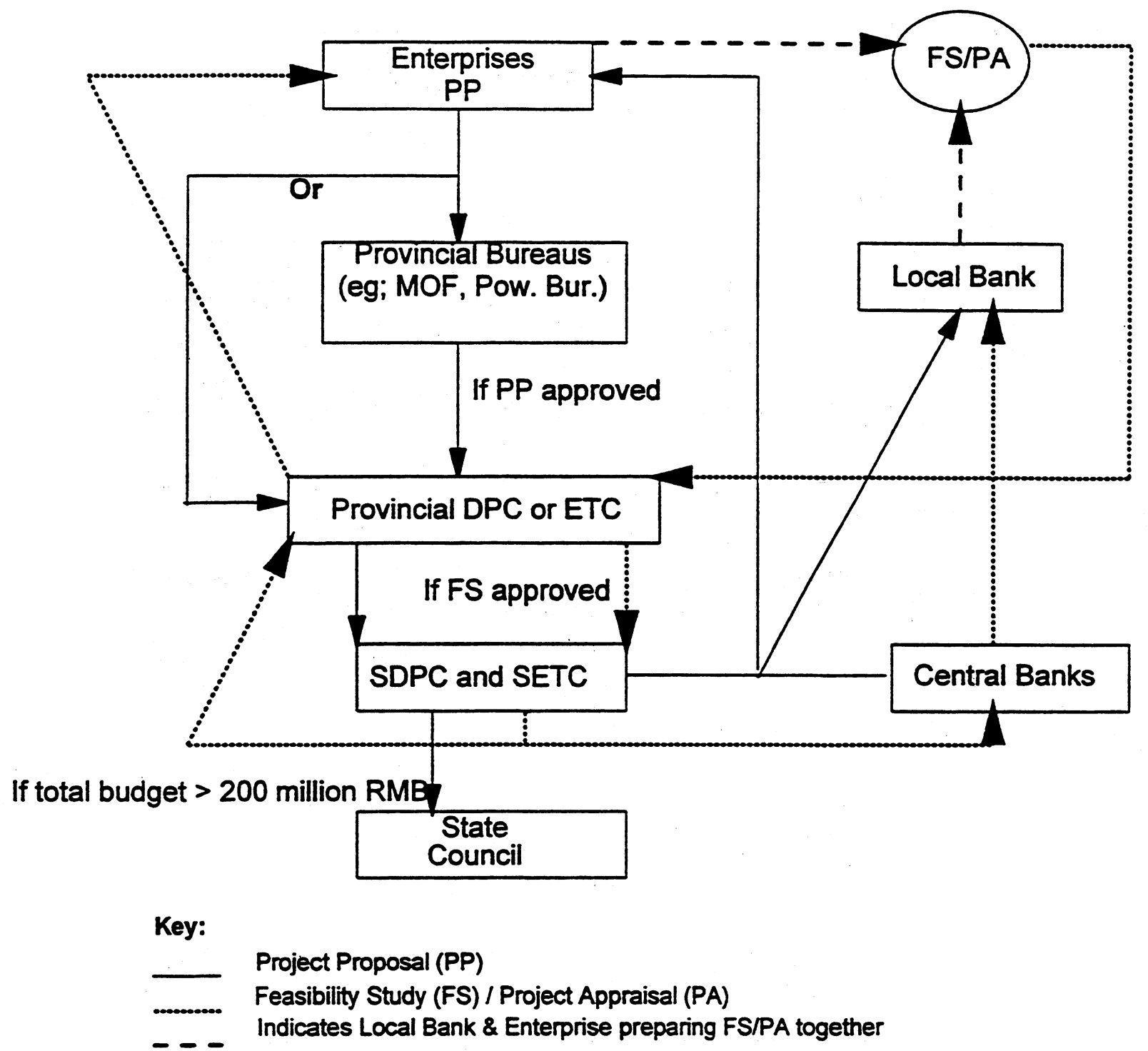

This procedure is meant for projects with total budgets valued at more than $\$ 30$ million U.S. for a State Development Planning Commission (SDPC) project (construction project) or $\$ 50$ million U.S. for a State Economic and Trade Commission (SETC) project (renovation project). This project should be approved by the central SDPC or SETC.

The enterprise first prepares its proposal and takes it to either the appropriate provincial bureau or the provincial branch of the DPC or ETC. If the proposal is approved, it is sent to the central branch of the SDPC or SETC for their approval. After the central SDPC and SETC reviews it with the Central Banks, the proposal is either approved or rejected. If approved, both the local bank and the enterprise will prepare a feasibility study, which needs the approval of the provincial DPC or ETC. After the feasibility study is approved, it is sent to the central SDPC and SETC for approval. If the central agencies approve the feasibility study, it is sent to the Central Banks for their review and authorization. At the same time, the local branch of the DPC and ETC is notified, and it, in turn, notifies the enterprise. Both the enterprise and the local bank will prepare a project appraisal that goes through the same approval procedure as the feasibility study. Once the project appraisal is approved, then the project is ready to be developed. If the project's budget is more than 200 million RMB, the State Council must approve the proposal. In special circumstances, such as with the 3 Gorges project, the People's Congress must approve the proposal. 


\section{Appendix D}

\section{Tied Aid and Foreign Assistance in China}

\begin{tabular}{|c|c|c|c|}
\hline Wind Farm Sites & Provinces & Foreign Loan Sources & Terms \\
\hline Pingtan & Fujian & Belgium Donation & $100 \%$ grant for $4 \times 200 \mathrm{~kW}$ Windmaster turbines \\
\hline Nan'Ao & Guangdong & DANIDA (Denmark) & $100 \%$ soft loan $(0 \%)$ interest @ 10-year payback \\
\hline Nan'Ao & Guangdong & U.S. Ex-Im Bank & Matching tied aid \\
\hline Dongfang & Hainan & KfW soft loan (Germany) & $40 \%$ soft loan $/ 60 \%$ commercial loan ( $1 \%$ interest for 20 -year payback $/ 8 \%$ for 10 -year payback \\
\hline Zhurihe & Inner Mongolia & Eldorado (Germany) & Up to $70 \%$ grant by BMFT; $30 \%$ to be paid for by Chinese for Husumer machines \\
\hline Shangdu & Inner Mongolia & None & None \\
\hline Huitengxile & Inner Mongolia & U.S. Ex-Im Bank & N/A \\
\hline $\mathrm{N} / \mathrm{A}$ & Inner Mongolia & MILIEV, Dutch Grant & $35 \%-60 \%$ grant by Dutch Ministry of Foreign Affairs; remaining balance to be financed by Chinese \\
\hline Xilinhot & Inner Mongolia & Eldorado (Germany) & Provides components@70\% grant; machines assembled in China \\
\hline Donggang & Liaoning & U.S. Ex-Im Bank & N/A \\
\hline Hengshen & Liaoning & $\mathrm{N} / \mathrm{A}$ & N/A \\
\hline Hengshan & Liaoning & None & None \\
\hline Rongcheng & Shangdong & None & None \\
\hline Changdao & Shangdong & KfW soft loan (Germany) & $40 \%$ soft loan $/ 60 \%$ commercial loan ( $1 \%$ interest for 20 -year payback $/ 8 \%$ for 10 -year payback \\
\hline Dabancheng & Xinjiang & Eldorado (Germany) & Provides $70 \%$ grant for Tacke and AN Bonus machines \\
\hline $\mathrm{N} / \mathrm{A}$ & Xinjiang & MILIEV, Dutch Grant & $35 \%-60 \%$ grant by Dutch Ministry of Foreign Affairs; remaining balance to be financed by Chinese \\
\hline \multirow[t]{3}{*}{ Burjin } & Xinjiang & German soft loan & Terms unavailable at the moment (probably the standard $0.75 \%$ over 40 -year payback) \\
\hline & Xinjiang & DANIDA Grant (Denmark) & $100 \%$ grant for $13 \times 150 \mathrm{~kW}$ machines \\
\hline & Xinjiang & DANIDA (Denmark) & $50 \%$ soft loan, $50 \%$ commercial ( $1 \%$ for 20 -year payback, $8 \%$ for 10 -year payback) \\
\hline Zhangbei & Hebei & German soft loan & Terms unavailable at the moment (probably the standard $0.75 \%$ over 40 -year payback) \\
\hline Kuocangnan & Zhejiang & DANIDA (Denmark) & $100 \%$ soft loan (0\% interest @ 10-year payback) \\
\hline Hedingshan & Zhejiang & $\mathrm{N} / \mathrm{A}$ & N/A \\
\hline \multirow[t]{2}{*}{ Sijiao } & Zhejiang & German Grant & $100 \%$ grant for 10 Aeroman $30-\mathrm{kW}$ machines for demonstration \\
\hline & & Spanish Government & $\begin{array}{l}44 \% \text { soft loan } / 56 \% \text { commercial }(0.25 \%-1 \% \text { interest, } 10 \text {-year grace period where interest only needs to } \\
\text { be paid; } 30 \text {-year total payback period) }\end{array}$ \\
\hline
\end{tabular}

Source: AWEA, January 16, 1998 


\title{
Appendix E
}

\section{THE SCALE-UP OF BIOMASS CIRCULATING FLUIDIZED BED GASIFIER}

\author{
Wu Chuangzhi Liu Ping Luo Zengfan Xu Bingyan Chen Yong \\ Guangzhou Institute of Energy Conversion, CAS \\ Guangzhou 510070, China
}

ABSTRACT: The large scale biomass circulating fluidized bed (CFB) gasifier is important to make use of biomass wastes and substitute for fossil energy. The biomass CFB gasifier is high efficiency and compact, and it is suitable to be enlarged. This paper discusses some major characters of biomass CFB gasifier and key technology to scale it up. The application status of biomass CFB gasifier in China also have been presented.

Key word: Biomass, CFB gasifier, Scale-up

\section{INTRODUCTION}

China has many kinds of biomass, and its amount is very huge. For example, Chinese agricultural residues is estimated to be about 500 million tons per years, and it can be used as fuel to substitute for more than 300 million tons of coal. Unfortunately, because its use is direct combustion, its efficiency is very low. Meanwhile, due to wide diversity of natural and social conditions in China vast territory, there is great disparity in making use of biomass among different regions. For example, in the inland of China, biomass is still the major rural energy, but in the coastal areas, it has been replaced by coal and petroleum gas. Consequently, much of the agricultural residue is burned in open fields and results in much air pollution and energy waste. Biomass gasification may make progress in both of above. Gasification can convert biomass into fuel gas, which can be used much more conveniently than can coal. In addition, because biomass gasification equipment is specifically designed for biomass, it is proper to handle any solid biomass resources industrially. As one of practical technology, biomass gasification has mainly been playing two roles in China. First, the biomass gasification supplies clean rural energy, such as electricity and town gas. It upgrades the rural life by changing the way of heating and cooking. Second, biomass gasification supplies cheap energy by making use of biomass wastes and makes a profit in such as gasification-combustion systems and gasification-generation systems. For the long-term applications, the development of biomass gasification is determined by economic viability and the demands of environment, and the economic viability seems much more important at present in China. From the economic point of view, it is inevitable to develop large-scale biomass gasifier because the large-scale biomass gasification not only can reduce per unit capital cost, but also can lower operation cost. Moreover, it is very important for the large-scale biomass gasifier to make full use of biomass wastes and substitute for fossil energy.

\section{THE PERFORMANCE OF BIOMASS CFB GASIFIER}

One major advantage of CFB biomass gasification is that the flying char can be recovered and gasification efficiency can be improved. The biomass CFB gasifier is suitable for any particle biomass, such as rice hulls, sawdust, crushed straw, etc. With favorable conditions of heat and mass transfer, fast pyrolysis is the main process in the CFB gasification, and the biomass CFB gasifier has high reaction rate and turns high-quality fuel gas Fig. $1^{[1]}$ shows the temperature profiles of a biomass CFB gasifier along the bed height. It can be found the temperature of biomass CFB gasifier is higher than $500^{\circ} \mathrm{C}$ and 
reaches maximum value at $1.0 \mathrm{~m}$ in height. This means that the effective reaction zone is much more than that of the fixed bed gasifier. ${ }^{[2]}$
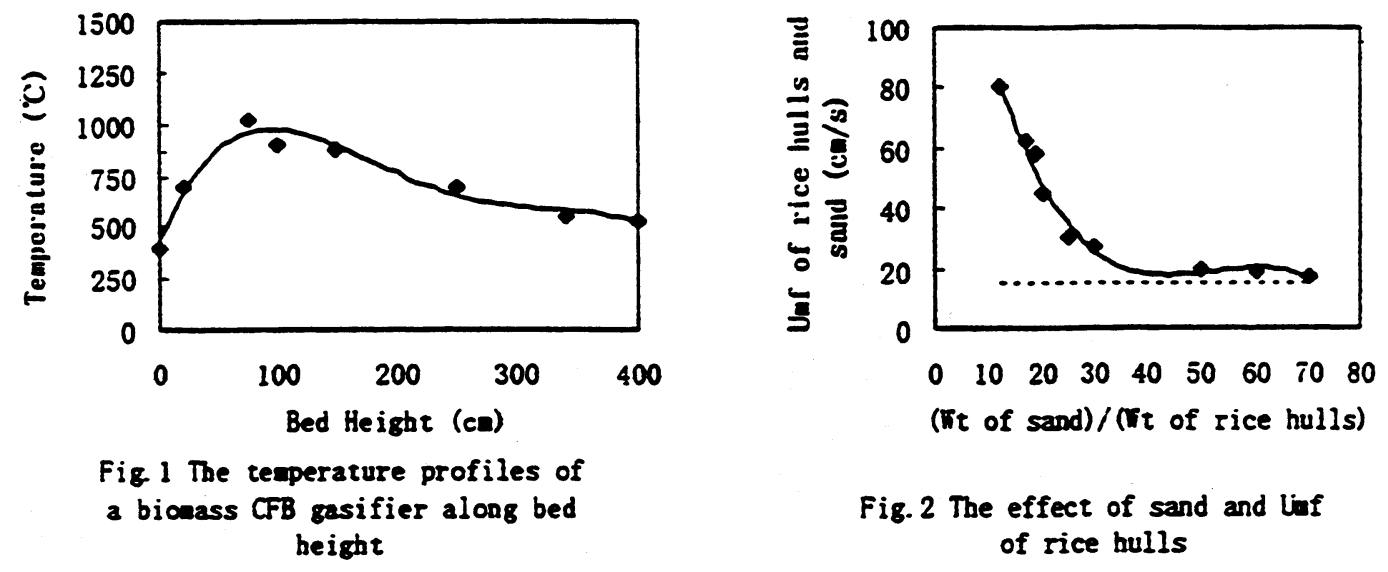

Fig. 2 The effect of sand and linf of rice hulls

Table 1. Operation Results of a Biomass CFB Gasifier

\begin{tabular}{|l|c|c|c|c|c|c|}
\hline No. & $\begin{array}{c}\text { Feeding } \\
\mathbf{K g} / \mathbf{h}\end{array}$ & $\begin{array}{c}\text { Temperature } \\
{ }^{\mathbf{}} \mathbf{C}\end{array}$ & $\begin{array}{c}\text { Fuel Gas } \\
\mathbf{m}^{\mathbf{3}} \mathbf{/ K g}\end{array}$ & $\begin{array}{c}\mathbf{L H V} \\
\mathbf{K J} / \mathbf{m}^{\mathbf{3}}\end{array}$ & $\begin{array}{c}\text { HT-EFF } \\
\mathbf{\%}\end{array}$ & $\begin{array}{c}\text { Productivity } \\
\mathbf{K g} / \mathbf{m}^{\mathbf{2}} \cdot \mathbf{h}\end{array}$ \\
\hline 1 & 240 & 864 & 1.72 & 7190 & 70.0 & 1818 \\
\hline 2 & 210 & 974 & 1.93 & 7264 & 74.6 & 1591 \\
\hline 3 & 180 & 1042 & 2.10 & 6938 & 78.3 & 1364 \\
\hline
\end{tabular}

Table 1 is the test result of a biomass CFB gasifier with a diameter of $410 \mathrm{~mm}$ and a height of $4000 \mathrm{~mm}$. The result shows that the productivity and fuel gas heating value from CFB gasifier are much higher than that from fixed bed gasifier, which are around $250 \mathrm{~kg} / \mathrm{m}^{2} \cdot \mathrm{h}$ and $5000 \mathrm{~kJ} / \mathrm{m}^{3}$, respectively. All data imply that the CFB gasifier is compact, and it is one of the best devices to be enlarged.

\section{THE KEY TECHNOLOGY FOR SCALE-UP BIOMASS CFB GASIFIER}

\subsection{Design of the biomass CFB gasifier}

An appropriate fast fluidization velocity is a prerequisite for designing an optimum fast fluidized bed. Unfortunately, because of various physical shapes and low density, fluidizing biomass is difficult, and channelling and stagnant areas occur easily. For example, rice hulls are very difficult to fluidize due to their cylindrical shape. Excessively high superficial velocities are required to fluidize whole rice hulls. From the presented result (see Fig. 2) ${ }^{[3]}$, it can be seen that the fluidization of rice hulls can be improved by adding small sand particles.

To improve the fluidization characteristics, it is necessary to mix sand or ash in with the biomass. The superficial velocity of different solid biomass, which is applicable to CFB gasification, should be determined by the experiment. On the other hand, because the large-scale biomass CFB gasifier usually operates at a different workload, the fluidization velocity of CFB gasifier changes considerably.

Consequently, at low workload, the fluidization velocity is too low to keep the fluidization steady and the biomass well-distributed. To overcome this disadvantage, the diameter of the fluidized bed can be designed as changing along the bed height (see Fig. 3). The small-diameter bed would make the fluidization process under good conditions when the CFB gasifier operates at low workload. Diameter can be determined by experience as follows: 


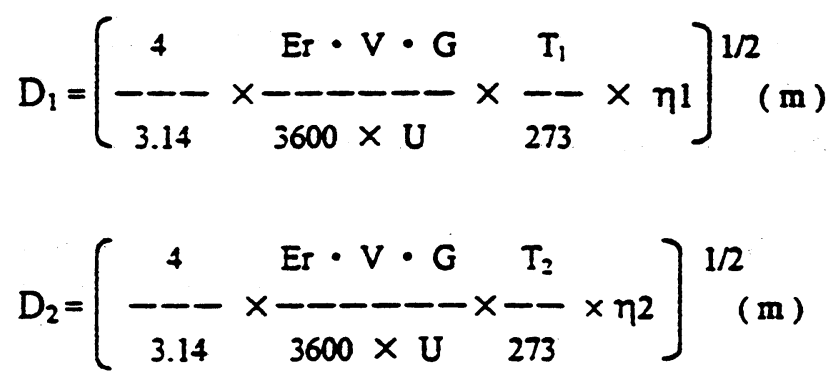

where:

$\mathrm{Er}=0.2-0.25$, equivalence ratio

$\mathrm{V}=$ stoichiometric air of unit biomass $\left(\mathrm{Nm}^{3} / \mathrm{kg}\right)$

$\mathrm{T}_{1}=$ temperature of combustion zone of gasifier $(\mathrm{K})$

$\mathrm{T}_{2}=$ temperature of the top of gasifier $(\mathrm{K})$

$\mathrm{U}=$ fluidization velocity $(\mathrm{m} / \mathrm{s})$

$\eta_{1}=40 \%$ (from our experience)

$\eta_{2}=70 / 50$ (from our experience)

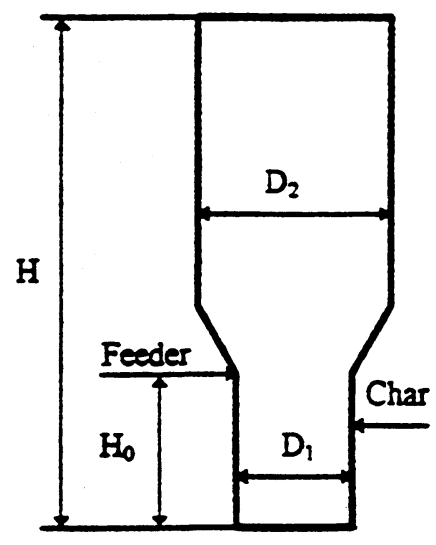

Fig. 3 Key parameters

of a CFB gasifier

The height of biomass CFB gasifier is determined by the gas resident time. It can be expressed as follows:

$$
\mathrm{H}=\mathrm{H}_{0}+\mathrm{Uxt}(\mathrm{m})
$$

where:

$\mathrm{H}_{0}=$ height of feeding point (m)

$\mathrm{t}=$ gas resident time $(\mathrm{s})$

The gas resident time is mainly associated with the tar cracking process. In biomass CFB gasifier, to reduce the tar product, it is necessary to ensure the gas resident time to be about 3 to 4 seconds. ${ }^{[4]}$

\subsection{Key processes of biomass $C F B$ gasifier}

- Gas-solid separating and char circulation: With char circulation, the CFB gasifier could diminish the carbon lost and get high efficiency. Nevertheless, the flying char particles are light and small, it is very difficult to be separated with simple separator. Additionally, the temperature and particles concentration of the product gas are both very high. This requires that the separator should be high efficiency and heat resisting. In practice, limitation is high temperature and operation cost make the cyclone most suitable, but it must be specially designed and calculated to meet the demand of CFB gasifier.

- Biomass collection and preparation: Since large-scale biomass gasifier consume enormous raw material, in order to provide enough biomass, the collection and transportation are necessary, especially for agricultural wastes. However, because of its dispersion and low energy density, the collection and transportation of biomass is very expensive. It is urgent to develop advanced technology for biomass collection and transportation. On the other hand, the biomass CFB gasifier requires some feedstock preparation processes, including drying and size reduction. Drying is necessary to reach a higher heating value of product gas. The moisture is recommended to range from $10 \%$ to $30 \%$. The feedstock particle size should be small to ensure that the biomass would be suitable for feeder. At present, the collection and transportation of agricultural wastes in large scale is difficult, but it is possible to do some preparation to meet the demand of CFB gasifier. 


\section{THE DEVELOPMENT OF BIOMASS CFB GASIFIER IN CHINA}

Guangzhou Institute of Energy Conversion has studied biomass CFB gasifier nearly ten years. According to various feedstock and particle size, several sets of biomass CFB gasifier have been developed which energy output range from 1.0 to 10.0 MW. Seven of them have operated in timber factories for several years, and one of them is being built. At present, in order to handle the wastes of rice hulls, a 7.0 MW biomass CFB gasifier has been designed, and it will turn out about $1.2 \mathrm{MW}$ of electricity.

The large-scale biomass CFB gasifier is one of the most promising technologies to fully make use of biomass resource. But very large biomass gasifier would not be applied widely at present in China because of the limitation of economic conditions. The large biomass CFB gasifier with capacity more than $10 \mathrm{MW}$ would only be suitable for some enterprises.

These enterprises should possess both conditions. One is a large supply of biomass in the surrounding area without excess need of collection and transportation. The other is notable returns and benefits, including saving energy and protecting the environment. For example, many timber factories have a lot of wood wastes, and the wood wastes are proper to be gasified and would substitute for much of fossil fuel. From an economic point of view, the middle-sized biomass gasification and generation system ranging about several megawatts are suitable for China. The biomass CFB gasifier would need to match these systems.

\section{Table 2. The Status of Biomass CFB Gasifiers in China}

\begin{tabular}{|c|c|c|c|c|c|c|c|c|}
\hline No. & $\begin{array}{c}\text { Start-up } \\
\text { Date }\end{array}$ & $\begin{array}{l}\text { Customer } \\
\text { Location }\end{array}$ & $\begin{array}{c}\text { Biomass } \\
(t / v)\end{array}$ & $\begin{array}{l}\text { Output } \\
\text { (MW) }\end{array}$ & Feedstock & Feeder & Size (m) & $\begin{array}{c}\text { Cost } \\
(\mathrm{y} / \mathbf{M W})\end{array}$ \\
\hline 1 & 1991.6 & $\begin{array}{c}\text { Zhanjiang } \\
\text { Guangdong }\end{array}$ & 2,000 & 0.9 & Wood wastes & L-valve & $\begin{array}{l}0.4(\mathrm{D}) \\
4.0(\mathrm{H})\end{array}$ & 165,000 \\
\hline 2 & 1993.1 & $\begin{array}{c}\text { Sanya } \\
\text { Hainan }\end{array}$ & 2,000 & 0.9 & Wood wastes & Screw & $\begin{array}{l}0.45(\mathrm{D}) \\
(4.0(\mathrm{H})\end{array}$ & 180,000 \\
\hline 3 & 1995.2 & $\begin{array}{l}\text { Wuyishan } \\
\text { Fujian }\end{array}$ & 2,500 & 1.2 & Wood wastes & Screw & $\begin{array}{c}0.5(\mathrm{~L}) \\
(0.5(\mathrm{~W}) \\
5.0(\mathrm{H})\end{array}$ & 160,000 \\
\hline 4 & 1995.6 & $\begin{array}{c}\text { Zhanjiang } \\
\text { Guangdong }\end{array}$ & 1,500 & 0.8 & Wood wastes & L-valve & $\begin{array}{l}0.4(\mathrm{D}) \\
4.0(\mathrm{H})\end{array}$ & 165,000 \\
\hline 5 & 1996.12 & $\begin{array}{c}\text { Nanhai } \\
\text { Guangdong }\end{array}$ & 6,500 & 5.0 & Wood wastes & Screw & $\begin{array}{c}1.0(\mathrm{~L}) \\
1.0(\mathrm{I}) \\
6.0(\mathrm{H}) \\
\end{array}$ & 70,000 \\
\hline 6 & 1997.8 & $\begin{array}{l}\text { Sanya } \\
\text { Hainan }\end{array}$ & 15,000 & 10.0 & Wood wastes & Screw & $\begin{array}{l}1.3(\mathrm{~L}) \\
1.3(\mathrm{~W}) \\
7.0(\mathrm{H})\end{array}$ & 40,000 \\
\hline 7 & 1997.9 & $\begin{array}{l}\text { Nanning } \\
\text { Guangxi }\end{array}$ & 15,000 & 10.0 & Wood wastes & Screw & $\begin{array}{l}1.3(\mathrm{~L}) \\
1.3(\mathrm{~W}) \\
7.0(\mathrm{H})\end{array}$ & 40,000 \\
\hline 8 & 1997.10 & $\begin{array}{l}\text { Putian } \\
\text { Fujian }\end{array}$ & 10,000 & 7.0 & Rice hulls & Screw & $\begin{array}{l}1.5(\mathrm{~L}) \\
1.5(\mathrm{~W}) \\
7.0(\mathrm{H})\end{array}$ & 45,000 \\
\hline
\end{tabular}




\section{References}

1. Wu Jianzhi, Xu Bingyan, Luo Zengfan and Zhou Xiguang: Performance analysis of a biomass circulating fluidized bed gasifier. Biomass and Bioenergy Vol. 3, No. 2. U.S.A. 1992.

2. Xu Bingyan, Luo Zengfan, Chen Guowei, Wu Chuangzhi and Yin Xiuli: Research and development of biomass utilization in China. Solar Energy in China. Proceedings of the High-level Expert Meeting for China. Beijing, China, 1995.

3. Bingyan $\mathrm{Xu}, \mathrm{W}$. Eric Huang, Virgil J. Flanigan and Oliver C. Sitton: Design and operation of a 6.0 inch fluidized bed gasifier for rice hulls. Energy from Biomass and Wastes IX, Florida, 1985.

4. Wu Chuangzhi, Xu Bingyan, Luo Zengfan and Yin Xiuli: Theory and application of biomass circulating fluidized bed gasifiers. Gas \& Heat Vol. 15, No. 5, Tianjing, China, 1995. 


\title{
Appendix F \\ Outline on the Geothermal Field in Rehai, Tengchong County, Yunnan Province, China
}

\author{
Geothermal Project Office \\ Yunnan Provincial Science \& Technology Commission \\ January 14, 1996
}

\section{Natural Geography}

From Tengchong county town to Kunming (by road) is $756 \mathrm{~km}$. The Geothermal field of Rehai is located $12 \mathrm{~km}$ to the southwest of the county town, with geographic coordinates of $24^{\circ} 51^{\prime}-24^{\circ} 58^{\prime} \mathrm{N}$ and $98^{\circ} 23^{\prime}-$ $98^{\circ} 28^{\prime} \mathrm{E}$, and an elevation of $1,098-1,912 \mathrm{~m}$.

Belonging to the subtropical climate of continental type, Tengchong County enjoys sufficient precipitation and mild weather, with a distinct division between the dry and wet season. Its annual average precipitation is $1,463.8 \mathrm{~mm}$, and its rainy season lasts from May to October, with $87 \%$ of yearly total rainfall. With annual evaporation of $1,600.7 \mathrm{~mm}$, and annual average temperature of $14.8^{\circ} \mathrm{C}$, its extreme high temperature goes up to $30.5^{\circ} \mathrm{C}$ while extreme low temperature goes down to $-4.2^{\circ} \mathrm{C}$.

The water system on ground surface with the field shows a distribution of twig shape. The surface runoff water changes as the season changes. The Dayingjiang River is the largest river within the region and flows from northeast to southwest across the entire field. The annual average runoff volume goes up to $8.76 \mathrm{~m}^{3} / \mathrm{s}$ at Tengchong Waterfall, $48.6 \mathrm{~m}^{3} / \mathrm{x}$ to the south of Lianghe county town. Along other secondary rivers, the runoff volumes in dry season are all more than $1 \mathrm{~m}^{3} / \mathrm{s}$.

\section{Regional Geology}

The Rehai geothermal field is located within the Tengchong metamorphic geological system at the eastern section of global Tethys construction, along the Alps-Himalayas, and within the low-pressure, high-temperature zone of lifting stretch portion at the eastern abutting crust on the collision between Indian plate and Euro-Asia plate.

\section{Stratigraphy and Magmatic Rock}

The oldest rock above the Rehai geothermal field belongs to the Proterozoic Gaolingongshan Group. The rock also emerges all around the geothermal field. The bore drilling in Songmuqing already touched the rock. It has been intruded by late Cretaceous $(68.8 \mathrm{Ma})$. Meanwhile, both are covered by uncomfortable strata on Miocene Nanlin Group. From the young to the old, its stratigraphic and petrologic sequences are separately described as follows:

- Holocene (Q4) stream alluviation and volcanic deposit

- Upper Pleistocene basalt (Q3b) olivine basalt (870,000 year)

- Lower Pleistocene andesite (Q1b) two pyroxene biotite andesite

- Pliocene basalt (N2m), olivine basalt, danubite 
The Miocene Nanlin Group (N1) is river facies macroclastic sediment intercalated with lake facies and burgy strata. In the geothermal field, it is divided into three sections as follows:

- Upper section: conglomerate rock, shingle intercalated with shallow siltstone plus shallow burgy

- Middle section: Granitic fine gravel and grit intercalated with pelitic siltstone and gravel

- Lower section: Granitic arenaceous gravel, gravel edge angle without sorting and in large variation, unconformably covered above Proterozoic and Mesozoic granite.

Cretaceous granite (K2G) within the Tengchong territory was intruded many times by Mesozoic granite, within the rock body. The Potassium Argon Age of pegmatite muscovit has been dated as 68.8 Ma.

The Proterozoic Gaoligong Group (PTGL) was mainly composed by clasolite, intercalated with few carbonatite and siliceous rock. Through metamorphism and migmatization, they have become various schist and migmatites of huge thickness.

\section{Structure}

The Rehai geothermal field is located in the turning portion extruding towards the southeast within the Guyong-Lianghe bogen structure. Faults dominate the geological structure of the field. The fault is almost in parallel with the south-north line and becomes the major structural body of the geothermal field (see Fig. 1).

\section{Geothermal Display}

Various types of geothermal display such as boiling springs, hot springs, warm springs, steam jets, steaming surface, natural sulfur, fiorite, adarce, salt tufa, and minerogenetic phenomena of hydrothermal gold and silver, hydrothermal rock erosion, hot water explosions, etc., have been found in the geothermal field. Hot water activities within the Rehai geothermal field could be divided into two display areas both at the east and the west. To the east is the Liuhuangtang (Huangguaqing-Songmuqing) geothermal display area; and to the west is the Reshuitang geothermal display areas (see Fig. 2).

\section{Liuhuangtang Geothermal Display Area}

At the elevation of 1,200-1,600 $\mathrm{m}$ above sea level, of an area $8.5 \mathrm{~km}^{2}$, Liuhuangtang (sulfur pool) sees many intensive hot water activities such as boiling springs, steam jet, steaming ground surface, a large area of fiorite distribution, and sulfur tufa extensively found on steaming ground surface, steamier and within rock fractures. From the center moving outwards, such four hot water altered zones as high silicified zone, low silicified zone, mixture zone of glimmerton, askanite and ancudite, as well as Kaolinized zone (see Table 1). 
Table 1. Summary of Hot Water Altered Zone Characteristics on Huangguaqing-Liuhuangtang Rock

\begin{tabular}{|c|c|c|c|c|}
\hline Name of & Altered Zone & $\begin{array}{l}\text { Altered Minterals of } \\
\text { Indicative Characteristics }\end{array}$ & Main Mineral Mix & Remarks \\
\hline Silicified & Strong & Silica Mineral & $\begin{array}{l}\alpha-\text { Quartz, } \\
\text { Chalcedony, Opal, } \\
\text { Amorphous, Sulfate, } \\
\text { Phospate, Natural } \\
\text { Sulphur }\end{array}$ & \multirow{4}{*}{$\begin{array}{l}\text { In the table: } \\
\text { M - Askanite } \\
\text { I - Glimmerton } \\
\text { K - Kaolinite } \\
\text { PI - Anorthose } \\
\text { Or - Potash } \\
\text { Feldspar } \\
\text { I\&M - Irregular } \\
\text { Mixture Minerals } \\
\text { Of Askanite and } \\
\text { Glimmerton }\end{array}$} \\
\hline Zone & Weak & Silica Mineral & $\begin{array}{l}\alpha-\text { Quartz, } \\
\text { Chalcedony, Opal, } \\
\text { Amorphous, Sulfate, } \\
\text { Phosphate, Natural } \\
\text { Sulphur }\end{array}$ & \\
\hline $\begin{array}{l}\text { Kaolinite } \\
\text { Askanite \& } \\
\text { Glimmerton } \\
\text { Mixture Zone } \\
\end{array}$ & M.I.K. I\&M & $\begin{array}{l}\text { M.I.K. I\&M } \\
\text { A - Quartz } \\
\text { A few of PI, Or }\end{array}$ & & \\
\hline $\begin{array}{l}\text { Kaolinized } \\
\text { Zone }\end{array}$ & $\mathrm{K}$ & $\begin{array}{l}\text { K, Or, PI } \\
\text { A - Quartz }\end{array}$ & & \\
\hline
\end{tabular}

There are 25 boiling and hot springs in the geothermal display area, including 11 boiling springs (see Table 2) with a spring flow rate of $11.37 \mathrm{~L} / \mathrm{S}$, natural heat flow rate of $74.19 \mathrm{MJ} / \mathrm{S}$.

Table 2. Statistics of Hot Springs in Liuhuangtang

\begin{tabular}{|c|c|c|c|c|c|c|c|c|c|}
\hline $\begin{array}{l}\text { Series } \\
\text { No. }\end{array}$ & \multicolumn{2}{|c|}{ Spring Code } & $\begin{array}{l}\text { Name of } \\
\text { Springs }\end{array}$ & Location & $\begin{array}{l}\text { Water } \\
\text { Temp }\end{array}$ & $\begin{array}{l}\text { Flow } \\
\text { Rate }\end{array}$ & PH & $\begin{array}{c}\text { Eh } \\
\text { Value }\end{array}$ & Remarks \\
\hline & Field & Uniformed & & & ${ }^{\circ} \mathrm{C}$ & $\mathbf{L} / \mathbf{S}$ & & & \\
\hline 1 & ES 10 & 0010 & & $\begin{array}{l}\text { West of Zhong } \\
\text { Xian Si Temple }\end{array}$ & 42 & 0.01 & 6.25 & & \\
\hline 2 & ES 11 & 0011 & & $\begin{array}{l}\text { West of Zhong } \\
\text { Xiao Si Temple }\end{array}$ & 39 & 0.35 & 5.27 & & \\
\hline 3 & ES 19 & 0019 & Hamazui & $\begin{array}{l}\text { West of Zeo Tang } \\
\text { He Waterfall }\end{array}$ & 97 & 0.40 & 8.20 & -125 & \\
\hline 4 & ES 20 & 0020 & & $\begin{array}{l}\text { West of Zao Tang } \\
\text { He Waterfall }\end{array}$ & 97 & 0.87 & 9.00 & & $\begin{array}{l}\text { Spring } \\
\text { group }\end{array}$ \\
\hline 5 & ES 21 & 0021 & & $\begin{array}{l}\text { West of Zao Tang } \\
\text { He Waterfall }\end{array}$ & 96.5 & 1.08 & 9.40 & -76 & $\begin{array}{l}\text { Spring } \\
\text { group }\end{array}$ \\
\hline 6 & ES 22 & 0022 & & $\begin{array}{l}\text { West of Zao Tang } \\
\text { He Waterfall }\end{array}$ & 94 & 0.71 & 9.45 & -146 & \\
\hline 7 & ES 23 & 0023 & & $\begin{array}{l}\text { West of Zao Tang } \\
\text { He Waterfall }\end{array}$ & 96 & 0.80 & 9.00 & -136 & \\
\hline 8 & ES 24 & 0024 & & $\begin{array}{l}\text { West of Zao Tang } \\
\text { He Waterfall }\end{array}$ & 97 & 1.57 & 9.25 & -128 & $\begin{array}{l}\text { Spring } \\
\text { group }\end{array}$ \\
\hline 9 & ES 25 & 0025 & & $\begin{array}{l}\text { West of Zao Tang } \\
\text { He Waterfall }\end{array}$ & 95 & 0.50 & 9.10 & +0.99 & \\
\hline 10 & ES 27 & 0027 & $\begin{array}{l}\text { Zhen Zhu } \\
\text { Quan }\end{array}$ & $\begin{array}{l}\text { Xian Ren Zao } \\
\text { Tang }\end{array}$ & 96 & 0.08 & 4.40 & +135 & $\begin{array}{l}\text { Spring } \\
\text { group }\end{array}$ \\
\hline 11 & ES 30 & 0028 & & $\begin{array}{l}\text { East of Zhong Yi } \\
\text { Yuan Bath }\end{array}$ & 82 & 0.10 & 3.30 & +0.93 & $\begin{array}{l}\text { Spring } \\
\text { group }\end{array}$ \\
\hline 12 & ES 31 & 0029 & & $\begin{array}{l}\text { On Chong Gou } \\
\text { Road, East of } \\
\text { Zhong Yi Yuan } \\
\text { Bath }\end{array}$ & 96 & 0.32 & 3.40 & +115 & $\begin{array}{l}\text { Spring } \\
\text { group }\end{array}$ \\
\hline
\end{tabular}




\begin{tabular}{|c|c|c|c|c|c|c|c|c|c|}
\hline 13 & ES 32 & 0030 & & $\begin{array}{l}\text { Under } 285 \mathrm{M} \\
\text { Road, South of } \\
\text { Liu Huang Tang }\end{array}$ & 95 & 0.30 & 9.30 & -56 & \\
\hline 14 & ES 39 & 0037 & & $\begin{array}{l}\text { Liu Huang Tang } \\
203^{\circ} 795 \mathrm{M}\end{array}$ & 73 & 0.17 & 6.60 & -0.34 & $\begin{array}{l}\text { Spring } \\
\text { group }\end{array}$ \\
\hline 15 & ES 40 & 0038 & & $\begin{array}{l}\text { Liu Huang Tang } \\
210^{\circ} 715 \mathrm{M}\end{array}$ & 62 & 0.03 & 7.00 & & \\
\hline 16 & ES 41 & 0039 & & $\begin{array}{l}\text { Liu Huang Tang } \\
213^{\circ} 845 \mathrm{M}\end{array}$ & 85 & 0.27 & 8.30 & -0.57 & $\begin{array}{l}\text { Spring } \\
\text { group }\end{array}$ \\
\hline 17 & AS 62 & 0061 & & $\begin{array}{l}20 \text { M North to Liu } \\
\text { Huang Tang }\end{array}$ & 45 & 0.04 & 3.16 & & \\
\hline 18 & AS 79 & 0078 & & $\begin{array}{l}250 \text { M North to } \\
\text { Liu Huang Tang }\end{array}$ & 95 & 0.12 & 7.70 & & \\
\hline 19 & Wn5 & Wn5 & & Xianren Bath & 50 & 0.45 & 6.40 & -0.08 & $\begin{array}{l}\text { Long-term } \\
\text { observation }\end{array}$ \\
\hline 20 & Wn6 & Wn6 & $\begin{array}{l}\text { Yang Jing } \\
\text { Quan }\end{array}$ & Xianren Bath & 97 & 0.22 & 9.00 & -143 & $\begin{array}{l}\text { Long-term } \\
\text { observation }\end{array}$ \\
\hline 21 & ES 29 & Wn7 & $\begin{array}{l}\text { Gu Ming } \\
\text { Quan }\end{array}$ & Xianren Bath & 99 & 1.19 & 9.50 & -163 & $\begin{array}{l}\text { Long-term } \\
\text { observation }\end{array}$ \\
\hline 22 & AS 94 & Wn8 & $\begin{array}{l}\text { Da Gun } \\
\text { Guo }\end{array}$ & Liu Huang Tang & 96 & 0.76 & 7.60 & -100 & $\begin{array}{l}\text { Long-term } \\
\text { observation }\end{array}$ \\
\hline 23 & Wn9 & Wn9 & & $\begin{array}{l}\text { West of Zhong } \\
\text { Xiao Si Temple }\end{array}$ & 97 & 0.11 & 7.10 & -0.43 & $\begin{array}{l}\text { Long-term } \\
\text { observation }\end{array}$ \\
\hline 24 & Wn10 & Wn10 & & $\begin{array}{l}\text { West of Ba Jiao } \\
\text { Yuan }\end{array}$ & 44 & 0.64 & 6.60 & -0.35 & $\begin{array}{l}\text { Long-term } \\
\text { observation }\end{array}$ \\
\hline 25 & ES 44 & 0568 & & $\begin{array}{l}\text { West of Ge Da } \\
\text { Shan }\end{array}$ & 25 & 0.28 & 8.50 & & \\
\hline Total & & & & & & 11.37 & & & \\
\hline
\end{tabular}

Within a display area of $6 \mathrm{~km}$ at an elevation of 1,200-1,500 M, Reshuitang sees a weaker intensity of geothermal display than Liuhuangtang - mainly a large area distribution of adarce and a few of sulfur tufa and salt tufa. Hot water altered zone becomes silicified, illite zone, silicified, Kaolinized zone. There are a total of 10 boiling and hot springs, including two boiling springs (see Table 3 ) with a spring water flow rate of $13.1 \mathrm{~L} / \mathrm{S}$, natural heat flow of $5.12 \mathrm{MJ} / \mathrm{S}$.

Table 3. Statistics of Hot Springs in Reshuitang

\begin{tabular}{|c|c|c|l|l|c|c|c|c|c|}
\hline $\begin{array}{c}\text { Series } \\
\text { No. }\end{array}$ & \multicolumn{1}{|c|}{ Spring Code } & $\begin{array}{c}\text { Name of } \\
\text { Springs }\end{array}$ & \multicolumn{1}{|c|}{ Location } & $\begin{array}{c}\text { Water } \\
\text { Temp }\end{array}$ & $\begin{array}{c}\text { Flow } \\
\text { Rate }\end{array}$ & PH & $\begin{array}{c}\text { Eh } \\
\text { Value }\end{array}$ & \multicolumn{1}{|c|}{ Remarks } \\
\hline & Field & Uniformed & & & L/S & & \\
\hline 1 & S001 & 0305 & & $\begin{array}{l}\text { Reshuitang Paper } \\
\text { Mill }\end{array}$ & 90.0 & 0.15 & 8.0 & & Spring group \\
\hline 2 & S002 & 0306 & $\begin{array}{l}\text { Xiao Gun } \\
\text { Guo }\end{array}$ & $\begin{array}{l}\text { Reshuitang Paper } \\
\text { Mill }\end{array}$ & 96.0 & 7.15 & 8.5 & Spring group \\
\hline 3 & S004 & 0307 & & $\begin{array}{l}\text { Reshuitang Paper } \\
\text { Mill }\end{array}$ & 30.3 & 0.01 & 7.5 & & \\
\hline 4 & W1 & 0337 & & North to Reshuitang & 75.0 & 0.14 & 7.5 & & \\
\hline 5 & W4 & 0340 & & East to Reshuitang & 26.0 & 0.01 & & & \\
\hline 6 & Wn2 & Wn2 & & Reshuitang & 74.4 & 0.86 & 6.8 & -0.30 & $\begin{array}{l}\text { Long-term } \\
\text { observation post }\end{array}$ \\
\hline 7 & Wn3 & Wn3 & & Reshuitang & 96.5 & 0.58 & 7.6 & -0.79 & $\begin{array}{l}\text { Long-term } \\
\text { observation post }\end{array}$ \\
\hline 8 & Wn4 & Wn4 & & Lianghe Bath & 71.0 & 2.17 & 7.2 & -0.22 & $\begin{array}{l}\text { Long-term } \\
\text { observation post }\end{array}$ \\
\hline 9 & S005 & 0308 & & Reshuitang & 59.0 & 0.61 & & & \\
\hline
\end{tabular}




\section{Chemical Properties of Geothermal Fluid}

The chemical categories of the hot water are mainly $\mathrm{HCO}_{3} \mathrm{Cl}-\mathrm{Na}$ type and $\mathrm{Cl}_{2} \mathrm{HCO}_{3}-\mathrm{Na}$ type, accounting for $39 \%$ and $25 \%$, respectively. Water of $\mathrm{SO}_{4}-\mathrm{Na}$ type and $\mathrm{HCO}_{3}-\mathrm{Na}$ type account for $11 \%$ (see Table 4 ). From the water of $\mathrm{HCO}_{3}-\mathrm{Na}$ type and $\mathrm{Cl}_{2} \mathrm{HCO}_{3}-\mathrm{Na}$ type evaporated gas is mainly $\mathrm{CO}_{2}$ (see Table 5).

Table 4. Statistics of Chemical Categories and Characteristics of Hot Spring Water in Rehai Geothermal Field ${ }^{1}$

\begin{tabular}{|c|c|c|c|c|c|c|c|c|c|c|c|}
\hline \multirow[t]{3}{*}{ Item Type } & \multirow[t]{3}{*}{ Distribution } & \multicolumn{2}{|c|}{$\mathbf{K}$} & \multicolumn{2}{|c|}{$\mathrm{Na}$} & \multicolumn{2}{|c|}{$\mathrm{Cl}$} & \multicolumn{2}{|c|}{ SO4 } & \multicolumn{2}{|c|}{ HCO3 } \\
\hline & & Limit & Common & Limit & Common & Limit & Common & Limit & Common & Limit & Common \\
\hline & & Mg & $\mathbf{L}$ & Mg & $\mathbf{L}$ & Mg & $\mathbf{L}$ & Mg & $\mathbf{L}$ & Mg & $\mathbf{L}$ \\
\hline $\mathrm{Cl}-\mathrm{Na}$ & Geothermal & 35.19 & 60 & 332.4 & 500 & 287.74 & 300 & 18.8 & 20 & 229.98 & 350 \\
\hline $\mathrm{ClSO}_{4}-\mathrm{Na}$ & Active & 1 & l & l & / & / & / & l & / & 1 & 1 \\
\hline $\mathrm{ClHCO}_{4}-\mathrm{Na}$ & Center & 125.12 & 100 & 844.85 & 700 & 696.15 & 500 & 60.0 & 30 & 1156.98 & 500 \\
\hline $\mathrm{HCO}_{3} \mathrm{Cl}-\mathrm{Na}$ & $\begin{array}{l}\text { Both sides of } \\
\text { the center }\end{array}$ & $\begin{array}{c}8.86 \\
/ \\
78.4\end{array}$ & $\begin{array}{c}20 \\
/ \\
50\end{array}$ & $\begin{array}{c}42.70 \\
/ \\
620.76\end{array}$ & $\begin{array}{c}160 \\
/ \\
450\end{array}$ & $\begin{array}{c}29.18 \\
/ \\
433.55\end{array}$ & $\begin{array}{c}100 \\
/ \\
300\end{array}$ & $\begin{array}{c}18 \\
/ \\
90\end{array}$ & $\begin{array}{c}16 \\
/ \\
35\end{array}$ & $\begin{array}{c}94.18 \\
/ \\
1206.53\end{array}$ & $\begin{array}{c}400 \\
/ \\
1000\end{array}$ \\
\hline $\begin{array}{l}\mathrm{SO}_{4}-\mathrm{Na} \\
\mathrm{SO}_{4} \mathrm{Cl}-\mathrm{Na}\end{array}$ & $\begin{array}{l}\text { Geothermal } \\
\text { Active } \\
\text { Center }\end{array}$ & $\begin{array}{c}0.50 \\
/ \\
17.71\end{array}$ & $\begin{array}{c}13 \\
/ \\
17\end{array}$ & $\begin{array}{c}28.76 \\
/ \\
66.52\end{array}$ & $\begin{array}{c}28 \\
/ \\
32\end{array}$ & $\begin{array}{c}6.67 \\
/ \\
29.86\end{array}$ & $\begin{array}{c}15 \\
/ \\
25\end{array}$ & $\begin{array}{c}60 \\
/ \\
265.48\end{array}$ & $\begin{array}{c}70 \\
/ \\
150\end{array}$ & $\begin{array}{c}0.0 \\
/ \\
3.77\end{array}$ & 0.0 \\
\hline $\begin{array}{l}\mathrm{HCO} 3-\mathrm{Na} \\
\mathrm{HCO} 3-\mathrm{Ca}\end{array}$ & $\begin{array}{l}\text { Edge of heat } \\
\text { Active } \\
\text { Zone }\end{array}$ & $\begin{array}{c}1.30 \\
/ \\
22.48\end{array}$ & & $\begin{array}{c}6.70 \\
/ \\
114.26\end{array}$ & & $\begin{array}{c}0.0 \\
/ \\
45.74\end{array}$ & & $\begin{array}{c}6.4 \\
/ \\
32.0\end{array}$ & & $\begin{array}{c}105.5 \\
/ \\
233.14\end{array}$ & \\
\hline
\end{tabular}

\begin{tabular}{|c|c|c|c|c|c|c|c|c|c|c|c|c|}
\hline \multirow[t]{3}{*}{ Item Type } & \multirow[t]{3}{*}{ Distribution } & \multicolumn{2}{|c|}{$\mathbf{F}$} & \multicolumn{2}{|c|}{$\mathrm{HBO}_{2}$} & \multicolumn{2}{|c|}{ As } & \multicolumn{2}{|c|}{$\mathrm{SiO}_{2}$} & \multicolumn{2}{|c|}{ Mineralization } & \multirow[t]{2}{*}{ PH } \\
\hline & & Limit & Common & \multirow{2}{*}{$\frac{\text { Limit }}{M g}$} & Common & \multirow{2}{*}{$\begin{array}{r}\text { Limit } \\
M g\end{array}$} & Common & \multirow{2}{*}{$\frac{\text { Limit }}{\mathrm{Mg}}$} & Common & \multicolumn{2}{|c|}{\begin{tabular}{l|l} 
Limit & Common \\
\end{tabular}} & \\
\hline & & Mg & $\mathbf{L}$ & & $\mathbf{L}$ & & $\mathbf{L}$ & & $\mathbf{L}$ & Mg & $\mathbf{L}$ & \\
\hline Cl-Na & Geothermal & 5.6 & 6 & 12.75 & 16 & 0.12 & 0.2 & 82.88 & 100 & 1531.6 & 1500 & 7.0 \\
\hline $\mathrm{ClSO}_{4}-\mathrm{Na}$ & Active & 1 & I & I & 1 & I & 1 & / & / & / & / & / \\
\hline $\mathrm{ClHCO}_{4}-\mathrm{Na}$ & Center & 14.0 & 11 & 39.94 & 26 & 1.255 & 0.6 & 174.74 & 150 & 3044.8 & 2400 & 9.5 \\
\hline & & 0.6 & 5 & 1.46 & 3.5 & 0.0 & & 21.1 & 70 & 217.11 & 1200 & 5.72 \\
\hline $\mathrm{HCO} 3 \mathrm{Cl}-\mathrm{Na}$ & Both Sides of & 1 & / & / & 1 & / & $<0.2$ & / & / & / & / & / \\
\hline & & 12.0 & 9 & 30.60 & 20 & 1.069 & & 175.6 & 120 & 2381.8 & 1800 & 9.0 \\
\hline $\mathrm{SO}_{4}-\mathrm{Na}$ & Geothermal & 0.08 & 0.2 & 0.39 & 0.8 & 0.005 & 0.06 & 56.58 & 70 & 208.6 & 200 & 3.16 \\
\hline $\mathrm{SO}_{4} \mathrm{Cl}-\mathrm{Na}$ & Active & 1 & I & I & I & / & / & 1 & / & / & / & 1 \\
\hline & Center & 0.6 & 0.6 & 2.58 & 1.0 & 0.198 & 0.1 & 168.51 & 130 & 546.24 & 300 & 4.4 \\
\hline $\mathrm{HCO}_{3}-\mathrm{Na}$ & Edge of heat & 0.8 & & 0.0 & & $<0.01$ & & 35.55 & & 204.47 & & 6.6 \\
\hline $\mathrm{HCO}_{3}-\mathrm{Ca}$ & active zone & I & & I & & I & & I & & / & & 1 \\
\hline & & 1.5 & & 2.53 & & 0.06 & & 93.43 & & 549.67 & & 8.5 \\
\hline
\end{tabular}

Table 5. Results of Gas Composition Chemical Analysis ${ }^{2}$

\begin{tabular}{|l|c|c|c|c|c|}
\hline Sampling Points & \multicolumn{5}{|c|}{ Gas Content (\% by Volume) } \\
\hline & $\mathbf{C O}_{\mathbf{2}}$ & $\mathbf{H}_{\mathbf{2}} \mathbf{S}$ & $\mathbf{C H}_{\mathbf{4}}$ & $\mathbf{N}_{\mathbf{2}}$ & $\mathbf{O}_{\mathbf{2}}$ \\
\hline Dagunguo & 49.7 & 14.3 & 0.25 & 29.46 & 6.55 \\
\hline Huangguaqing & 44.6 & Trace & 0.4 & \multicolumn{2}{|c|}{54.9} \\
\hline Reshuitang & 69.2 & 0.0 & 0.0 & 27.75 & 7.02 \\
\hline
\end{tabular}

Between the two display areas, the $\mathrm{Ca}, \mathrm{Mg}$ ion contents in the hot water differ from each other (see Table 6). 
Table 6. Characteristics of Ca Mg Contents in Hot Spring Water

\begin{tabular}{|c|c|c|c|c|c|c|c|c|}
\hline \multirow{4}{*}{$\begin{array}{l}\text { Ion } \\
\text { Spring }\end{array}$} & \multicolumn{4}{|c|}{ Liu Huang Tang } & \multicolumn{4}{|c|}{ Re Shui Tang } \\
\hline & \multicolumn{2}{|c|}{$\mathbf{C a}$} & \multicolumn{2}{|c|}{ Mg } & \multicolumn{2}{|c|}{$\mathbf{C a}$} & \multicolumn{2}{|c|}{ Mg } \\
\hline & Limit & Common & Limit & Common & Limit & Common & Limit & Common \\
\hline & \multicolumn{2}{|c|}{$\mathrm{Mg} / \mathrm{L}$} & \multicolumn{2}{|c|}{$\mathrm{Mg} / \mathrm{L}$} & \multicolumn{2}{|c|}{$\mathrm{Mg} / \mathrm{L}$} & \multicolumn{2}{|c|}{$\mathrm{Mg} / \mathrm{L}$} \\
\hline $\begin{array}{l}\text { Low temp } \\
\text { spring }\end{array}$ & $2.81-29.56$ & & $2.27-7.22$ & & & & & \\
\hline $\begin{array}{l}\text { Middle temp } \\
\text { spring }\end{array}$ & $1.71-3.0$ & & $0.52-2.27$ & & & & & \\
\hline $\begin{array}{l}\text { High-middle } \\
\text { temp } \\
\text { Spring }\end{array}$ & 1.54 & & 0.01 & & $\begin{array}{l}23.97- \\
24.83\end{array}$ & & $\begin{array}{l}4.15- \\
4.93\end{array}$ & \\
\hline $\begin{array}{l}\text { Boiling, high } \\
\text { Temp springs }\end{array}$ & Trace-11.31 & $<1$ & $\begin{array}{l}\text { Trace- } \\
2.44\end{array}$ & $<0.6$ & 7.28 & & 3.12 & \\
\hline
\end{tabular}

\section{Conceptual Models}

\section{Heat Reservoir}

\section{Reservoir temperature:}

Calculated with geochemical temperature standards, the reservoir temperature in Liuhuangtang is $238^{\circ} \mathrm{C}$. Shallow reservoir temperature is $164^{\circ} \mathrm{C}$. In Reshuitang, the reservoir temperature is $220^{\circ} \mathrm{C}$, meanwhile with a shallow reservoir temperature of $145^{\circ} \mathrm{C}$.

\section{Heat reservoir strata}

Belonging to late Mesozoic Granite and Pre-Cambrian Gaoligongshan Group, their structural fractures have developed very much. The rate of fractures generally reaches between $2 \%$ and $10 \%$ in the shape of banded reservoir or stratoid reservoir.

\section{Covering strata of heat reservoir}

Belonging to the Nanlin Group, Miocene, Tertiary System, the strata have a poor permeability, a stronger clay grouting, also with undeveloped pores and fractures.

\section{Heat Source}

Beneath the geothermal field about $7 \mathrm{KM}$, there is a pocket of magma which is under cooling, however, its crust temperature still remains around $500^{\circ} \mathrm{C}$. The emplacement age of the magma pocket was about late Pleistocene (see Fig. 3).

\section{Exploration Engineering Arrangement}

Explorative survey and studies on Rehai Geothermal Field, although with over 20 year history have been limited into surface work. Some drillings could only collect a few information on shallow strata. The supplementary survey in 1995 has arranged the deep drilling in order to clarify this geothermal resource. By completing a drill of industrial fluid $>150^{\circ} \mathrm{C}$, necessary parameters for construction of over $10 \mathrm{MW}$ generator are to be provided. At present, five bores are to be preliminarily suggested for drilling, formulating four schemes for review and decision making (see Tables 7 and 8). 
Table 7. Summary of Engineering Drillings

\begin{tabular}{|l|l|l|l|}
\hline Bore Code & Depth (M) & Purposes & Evidence \\
\hline RK1 & 1550 & Search F6 & $\begin{array}{l}\text { Distinct traces, strong geothermal display, } \\
\text { ZK } 1607142^{\circ} \mathrm{C} .\end{array}$ \\
\hline RK2 & 1700 & $\begin{array}{l}\text { Search F6 Low Velocity } \\
\text { Zone }\end{array}$ & $\begin{array}{l}\text { F6 clear, seismic measures a low velocity } \\
\text { zone, south bore temp. 50 }{ }^{\circ} \mathrm{C} \text { and } 86^{\circ} \mathrm{C} .\end{array}$ \\
\hline RK3 & 1500 & Search Deep Reservoir & $\begin{array}{l}\text { Complex structure, strong alteration, CK4 } \\
\text { at Southwest, Temp. Gradient } \\
9.15^{\circ} \mathrm{C} / 100 \mathrm{~m} \text {, strong geothermal display } \\
\text { at Northwest. }\end{array}$ \\
\hline RK4 & 1500 & Search Deep Reservoir & $\begin{array}{l}\text { Seismic low velocity zone, chemical } \\
\text { measure shows one of heat centers, minus } \\
\text { abnormal gravity, MT low resistance, CK } \\
\text { temp. gradient 7.76 }\end{array}$ \\
\hline RK5 & 1600 & Search Deep Reservoir $\mathrm{m}$. \\
\hline & $\begin{array}{l}\text { F41 faults, MT low resistance, Minus } \\
\text { abnormal gravity, Bore temp. gradient } \\
43^{\circ} \mathrm{C} / 100 \mathrm{~m} .\end{array}$ \\
\hline
\end{tabular}

Table 8. Summary of Drilling Implementation

\begin{tabular}{|l|l|l|l|l|l|l|}
\hline $\begin{array}{c}\text { Bore } \\
\text { Scheme }\end{array}$ & RK1 & RK2 & RK3 & RK4 & RK5 & $\begin{array}{l}\text { Accumulated } \\
\text { Drilling (M) }\end{array}$ \\
\hline 1 & $>150^{\circ} \mathrm{C}$ & & $>150^{\circ} \mathrm{C}$ & & & 4550 \\
\hline 2 & $<150^{\circ} \mathrm{C}$ & $>150^{\circ} \mathrm{C}$ & & & & 4750 \\
\hline 3 & $>150^{\circ} \mathrm{C}$ & & $<150^{\circ} \mathrm{C}$ & & & 4550 \\
\hline 4 & $<150^{\circ} \mathrm{C}$ & $<150^{\circ} \mathrm{C}$ & & & & 3250 \\
\hline
\end{tabular}




\section{Figure 1. Structural Map of Regional Geology in Rehai Geothermal Field}

\section{Legend}

1. Actually measured and estimated normal faults and their numbers

2. Actually measured and estimated reverse faults and their numbers

3. Actually measured and estimated strike slip faults and their numbers

4. Actually measured and estimated faults of uncertain nature and their numbers

5. Estimated occult Dayingjiang faults and their numbers

6. Anticlinal axes and their numbers

7. Synclinal axes and their numbers

8. Actually measured and estimated geological boundaries

9. Boundaries of unconformable strata

10. Stratigraphic occurrence

11. Schistosity occurrence

12. Planar flow occurrence

13. Paroxysmal volcano vent, burst volcano vent

14. Granite

15. Dacite

16. Andesite

17. Basalt

18. Volcanic agglomerate breccia

\section{Figure 2. Distribution Scope of Rehai Geothermal Field}

\section{Legend}

1. Boundary of the geothermal field

2. Boundary of the high-temperature heat reservoir

3. Geological boundary

4. Hot springs number at left, water temp. (jae) at right

5. Well drillings, number at left

6. Temperature measuring drills, number at left, temperature gradient $\left({ }^{\circ} \mathrm{C}\right.$ per $\left.100 \mathrm{~m}\right)$ at right

7. Actually measured and estimated normal faults and their numbers

8. Actually measured and estimated reverse faults and their numbers

9. Actually measured and estimated strike-slip faults and their numbers

10. Actually measured and estimated faults of uncertain nature

11. Quaternary system

12. Tertiary system, Nanlin group

13. Carboniferous system

14. Proterozoic Gaoligongshan group

15. Upper and lower Pleistocene volcanic rock

16. Tertiary volcanic rock

17. Yenshan period granite

18. Crater and residential place 
Figure 3. Illustration on Conceptual Model of Rehai Geothermal Field Formation

\section{Legend}

1. Upper Tertiary System

2. Proterozoic Group

3. Yenshan Period Granite

4. Geothermal fluid

5. Hot springs

6. Moving route of atmospheric precipitation and underground water

7. Faults and their numbers

8. Heat reservoir

9. Magma pocket under cooling 


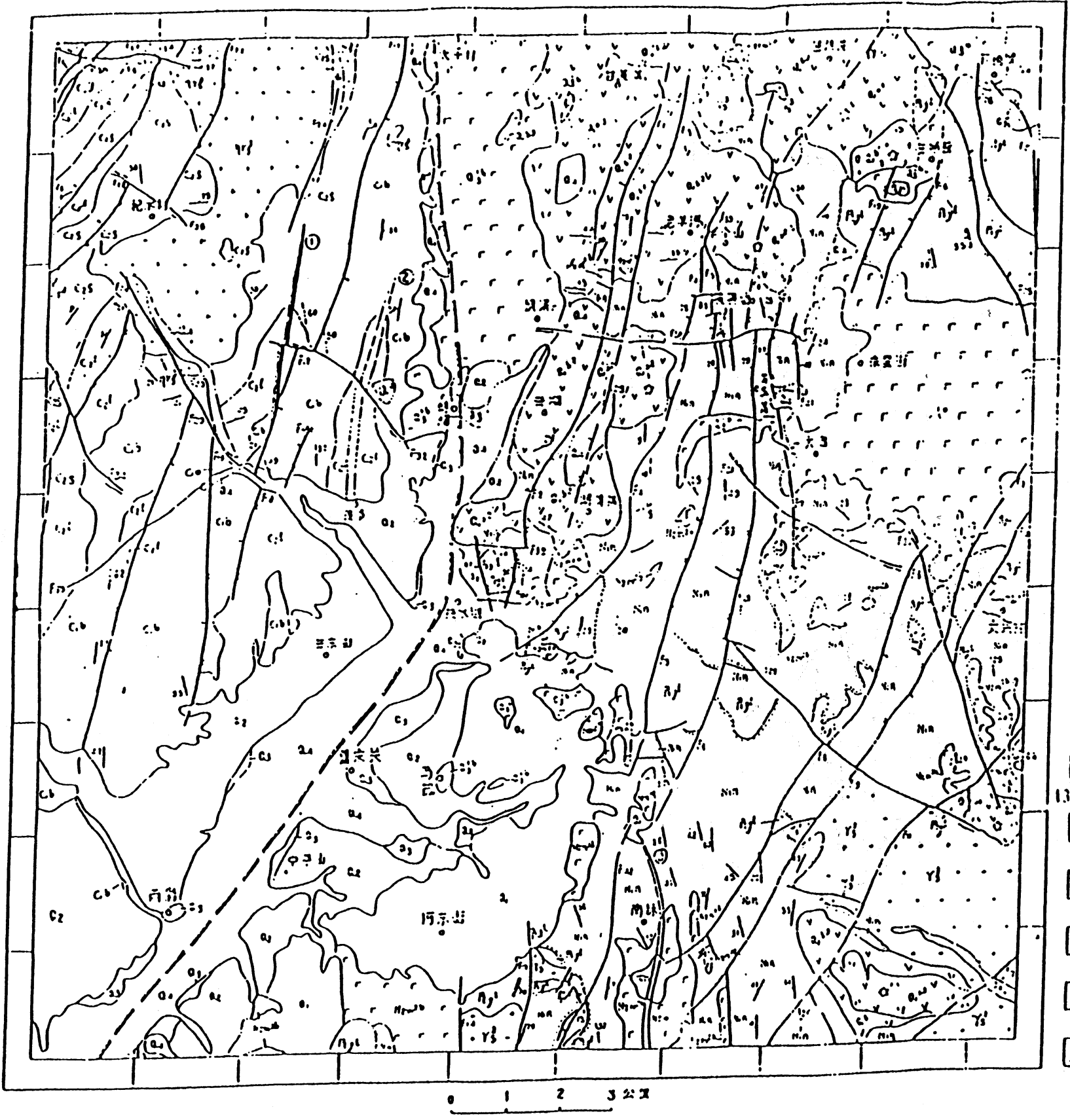

\author{
[何 \\ Legend

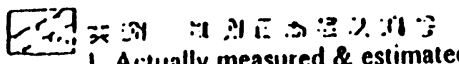 \\ 1. Actually measured \& estimate \\ normal faults and lieir numbers \\ Actually measured \& estimated \\ reverse faults and their numbers \\ 3. Aclually measured \& estimated \\ strike slip faults and their numbers \\ -1.7 4 Actually measured \& estimated faults \\ of uncertain nature and their numbers

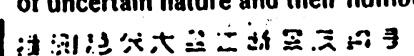 \\ 5. Estimated occult Dayingjiang faults \\ and their numbers \\ 6. Anticlinal axes and their numbers

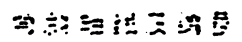 \\ 7. Synclinal axes and their numbers

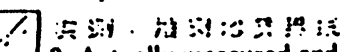 \\ 8. Actually measured and estimaled \\ geological boundaries

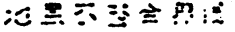 \\ 9. Boundaries of uncomformable strata
}

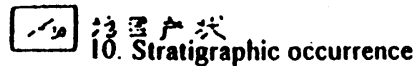

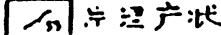

11. Schistosity occurrence

/2 绝西文状

12. Planar flow occurrer:ce

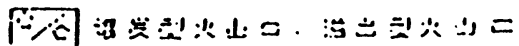

13. Paroxysnial volcano vent, Burst volcano vent

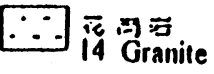

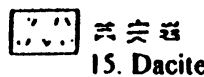

$\therefore$ 完山迢

16. Andesite

달

$\therefore \because \therefore$ 山.

18. Volcanic agglomerate breccia

Fig. I. Structural Map of Regional Geology in Rehai Geothermal Field 


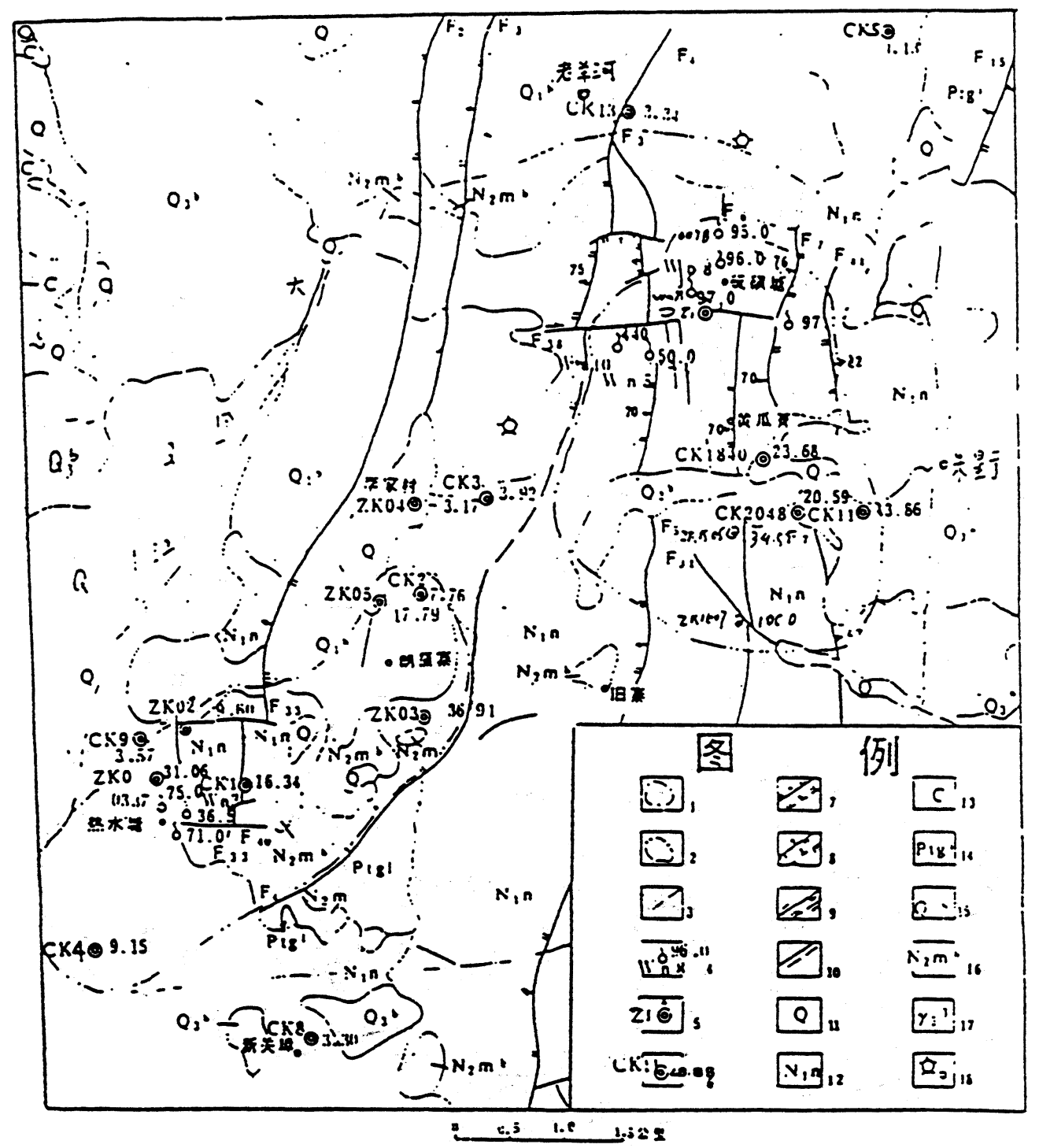

Fig. 2. Distribution Scope of Rehai Geothermal Field

1. Boundary of the geothermal field

2. Boundary of the high temperaure heat reservoir

3. Geological boundary

4. Hot springs Number at left. water temp $(i z)$ at right

5. Well drillings. Number at left

6. Temperature, measuring drills, Number at left. Temperature gradiem ( ${ }^{\circ} \mathrm{C}$ per $100 \mathrm{mI}$ ) at right

7. Actually measured and estimated normal faults and their numbers

8. Actually measured and estimated reverse faults and their numbers

9. Actually measured and estimated strike-slip faults and their numbers

10. Actually measured and estimated faults of uncertain nature

11. Quaternary system

12. Tertiary system, Nanlin group

13. Carboniferous system

14. Proterozoic Gaoligongshan group

15 Upper and lower Pleistocene volcanic rock

16. Tertiary volcanic rock

17. Yenshan period granite

18. Crater and residential place 
Fig. 3 Illustration on Conceptual Model of Rehai Geuthermal Field Formation

1 Upper Tertiary System

2. Proterozoic Group

3. Yenshan Period Granite

4. Geothermal Fluid

5. Hot Springs

6. Moving Route of Aimospherical Precipitation and Underground Water

7. Faults and their numbers

8. Heat Reservoir

9. Magmn Pocket under Cooling

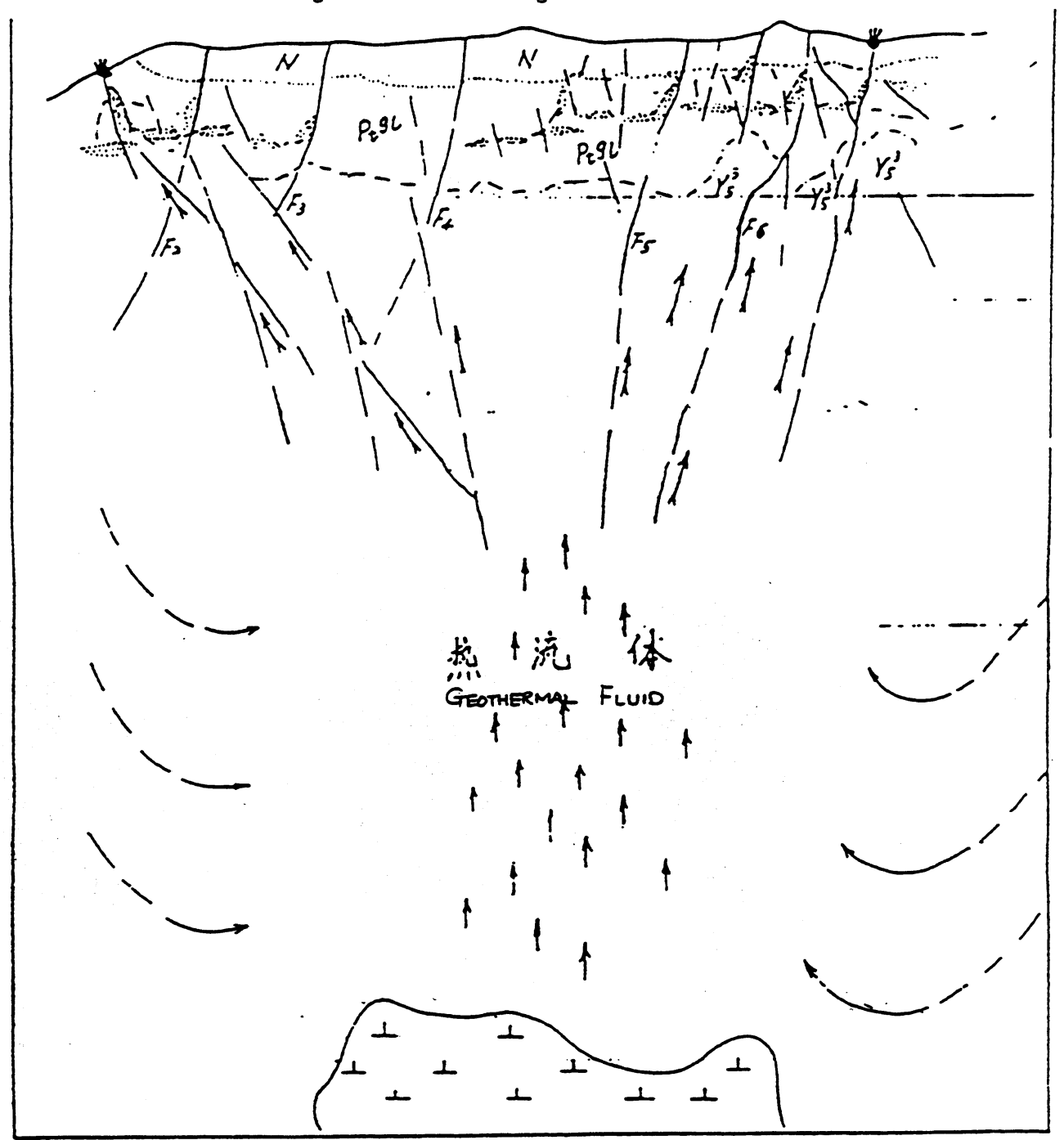

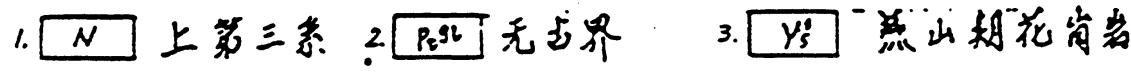

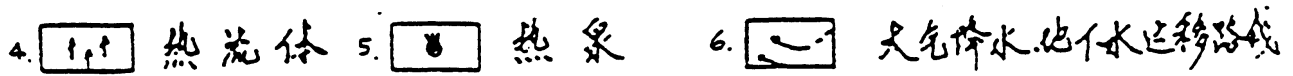

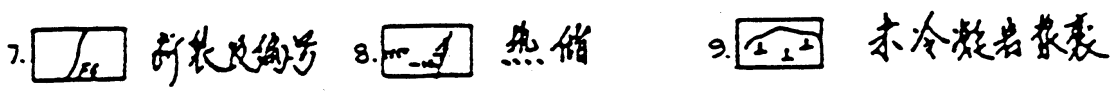

终3热等热田形成捪念模型示意图。 


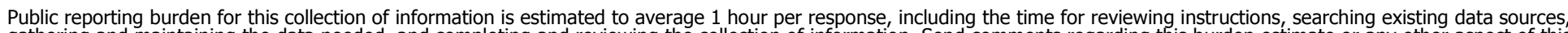

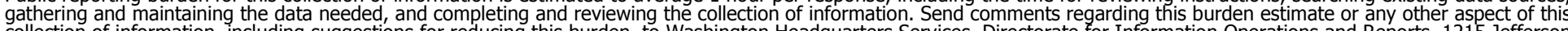

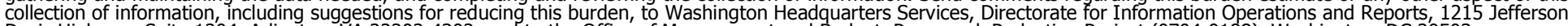

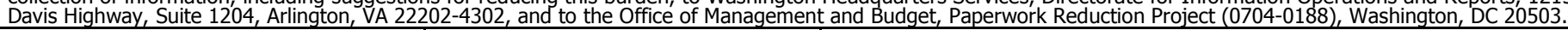

\begin{tabular}{|l|l|l} 
1. AGENCY USE ONLY (Leave blank) & $\begin{array}{l}\text { 2. REPORT DATE } \\
\text { December } 1999\end{array}$ & $\begin{array}{l}\text { 3. REPORT TYPE AND DATES COVERED } \\
\text { Subcontract Report }\end{array}$ \\
\hline
\end{tabular}

4. TITLE AND SUBTITLE Renewable Energy Markets I

China: An Analysis of Renewable Energy Markets in Guangdong, Jiangxi, Jilin, and Yunnan Provinces, with Updated Information from Beijing $\mathrm{n}$

5. FUNDING NUMBERS

PV90.9002

6. AUTHOR(S) Scott B. Vaupen

7. PERFORMING ORGANIZATION NAME(S) AND ADDRESS(ES)

Xinergy Resources

71 Rosewood Drive

8. PERFORMING ORGANIZATION REPORT NUMBER

San Francisco, CA 94127

9. SPONSORING/MONITORING AGENCY NAME(S) AND ADDRESS(ES)

National Renewable Energy Laboratory

10. SPONSORING/MONITORING

1617 Cole Blvd.

Golden, CO 80401-3393

\section{SUPPLEMENTARY NOTES}

NREL Technical Monitor: Debra Lew

12a. DISTRIBUTION/AVAILABILITY STATEMENT National Technical Information Service 12b. DISTRIBUTION CODE

U.S. Department of Commerce

5285 Port Royal Road

Springfield, VA 22161

13. ABSTRACT (Maximum 200 words)

The People's Republic of China has undergone many changes over the past decade that have led to new growth and created opportunities for many industries, including the renewable energy industry. China has consistently had one of the fastest-growing economies in Asia. This report is a continuation of a market assessment done in 1997, which analyzed six provinces (Inner Mongolia, Gansu, Shandong, Qinghai, Xinjiang, and Zhejiang) in China. The information contained in this report comes mainly from interviews conducted with central and local government officials, state and local power bureau officials, and various company executives. The report provides valuable market information necessary for any company interested in entering China's renewable energy market. It also details the legal, competitive, sociocultural, technological, geographic, and economic environments of four provinces in ChinaGuangdong, Jiangxi, Jilin, and Yunnan. In addition, it outlines the major central government policies and contacts important to renewable energy development within China.

14. SUBJECT TERMS photovoltaics; renewable energy; foreign markets; China's PV markets

15. NUMBER OF PAGES

16. PRICE CODE

17. SECURITY CLASSIFICATION OF REPORT

Unclassified
18. SECURITY CLASSIFICATION OF THIS PAGE Unclassified
19. SECURITY CLASSIFICATION OF ABSTRACT Unclassified
20. LIMITATION OF ABSTRACT

UL 